\title{
AL SERVICIO DEL CLAUSTRO. ANÁLISIS DE LOS ESPACIOS DE TRABAJO EN LOS MONASTERIOS HISPÁNICOS (SIGLOS XI-XIX)
}

\author{
POR \\ Alejandro García Álvarez-Busto* \\ Universidad de Oviedo \\ garciaalejandro@uniovi.es/alesga_op@yahoo.es
}

\section{RESUMEN}

Este artículo tiene como objetivo fundamental el análisis de las comunidades claustrales desde el punto de vista de los espacios de trabajo y las infraestructuras existentes en el edificio monástico, y de cómo condicionaron la vida de los monjes y de los trabajadores seglares que integraban la familia monástica. Pretende además incorporar a esta línea de investigación las aportaciones de la arqueología de las últimas décadas, sirviendo de revisión del estado de la cuestión para la Península Ibérica durante la época medieval y moderna. El resultado es una visión del monasterio como un complejo en el que alrededor de la clausura, el ámbito de los monjes, se extiende un espacio laboral y productivo atendido en buena medida por los laicos que se encontraban al servicio del claustro.

PALABRAS CLAVE: Monasterio, trabajadores laicos, tecnología, infraestructura, vida cotidiana, Edad Media y Moderna.

\section{SERVING THE CLOISTER. ANALYSIS OF WORKSPACES IN HISPANIC MONASTERIES (XI-XIX CENTURIES)}

\begin{abstract}
The main purpose of this paper is the analysis of cloistered communities from the point of view of the workspaces and infrastructure in the monastic site, and how conditioned the lives of monks and lay workers who formed the monastic family. Also intends to integrate in this research contributions of archeology in recent decades, serving of review for the Iberian Peninsula during the Middle and Modern Ages. The result is a view of the monastery as a complex in which around the cloistered space, the scope of the monks, a working and productive space extends mainly attended by the laity who were in the service of the cloister.
\end{abstract}

KEY WORDS: Monastery, lay workers, technology, infrastructure, everyday life, Middle and Modern Age

Recibido/Received 08-07-2014

Aceptado/Accepted 21-05-2015

\section{INTRODUCCIÓN}

Cuando pensamos en un monasterio la imagen más recurrente es la de un grupo de monjes entregados al oficio divino, olvidándonos que en muchos de estos recintos religiosos el número de laicos era mayor que el de los propios profesos. ${ }^{1}$ Debido a ello es muy poco lo que sabemos sobre

Área de Arqueología del Departamento de Historia. Facultad de Filosofía y Letras de la Universidad de Oviedo. garciaalejandro@ uniovi.es. Grupo de Investigación en Arqueología Antigua y Medieval (ARQUEOS).

1 Como ocurría por ejemplo en Glastonbury en tiempos del abad Enrique de Sully, donde trabajaban más de ochenta sirvientes encargados de mantener a unos sesenta monjes, Linage Conde, A. 2007: 74. Henry de Soilli gobernó la famosa abadía inglesa a finales de la duodécima centuria, y durante su mandato fue descubierto el supuesto sepulcro del legendario rey Arturo. estos trabajadores al servicio del claustro, ya que por norma general la historiografía que se ha ocupado de las comunidades monásticas lo ha hecho dedicando mayor atención al análisis de los usos litúrgicos y los ritos que regían la vida en común, y los historiadores que se han preocupado por estudiar el edificio monástico se han interesado sobremanera por desgranar su morfología y sus diferentes fases constructivas, atendiendo principalmente al templo y al conjunto de dependencias principales organizadas en torno al claustro. Por el contrario todavía es mucho lo que desconocemos sobre cómo se organizaban las dependencias de trabajo o las infraestructuras de servicio en el interior de estos recintos, y de cómo eran las condiciones vitales y laborales de aquellos trabajadores que solventaban las demandas señoriales de los monjes, o de la preocupación de estos últimos por asuntos tan terrenales como el bienestar, la alimentación o la higiene. 
Y aunque en teoría son éstas cuestiones con una alta dosis de materialidad que podrían haber sido afrontadas desde el método arqueológico, en la práctica contamos con bastante información pero con pocos abordajes por parte de la investigación. ${ }^{2}$ Por esta razón el presente artículo tiene entre sus objetivos fundamentales realizar una revisión y ordenación del estado de conocimiento de la arquitectura monástica de época medieval y moderna en la Península Ibérica desde una perspectiva socioeconómica y laboral, atendiendo a las dependencias vinculadas a la economía productiva desarrollada en el edificio monástico, entendiendo éste como la cabeza rectora de un señorío, así como a aquellas otras infraestructuras que estaban orientadas al mantenimiento del propio edificio y a satisfacer las necesidades de la comunidad que lo habitaba.

Evidentemente, y dada la amplitud del objeto de estudio, el trabajo no presenta un carácter sistemático, sino que más bien debe ser entendido como un primer estado de la cuestión que pretende poner de relieve las posibilidades que ofrece la arqueología a la hora de contribuir a ampliar y mejorar nuestro conocimiento sobre los trabajos desarrollados en un monasterio y aquellos aspectos más cotidianos de la vida monástica, poniendo el acento en el estudio de las dependencias de trabajo y de servicio, por lo general topográficamente extra-claustrales. ${ }^{3}$

Desde este postulado resulta fundamental tener en cuenta que la familia monástica no solo se componía de los monjes, los novicios y los legos o conversos, sino también de un considerable número de laicos que se ocupaban de una buena parte de los diferentes trabajos necesarios en el recinto monástico. Su presencia en los monasterios ya aparece recogida en el Capítulo LVII de la regla de San Benito, y su situación jurídica y su protagonismo laboral serán muy variados dependiendo de cada orden y de cada época, ${ }^{4}$ revelándose en la documentación escrita de diferentes formas: siervos, donados (oblati), criados y paniaguados, trabajadores asalariados (mercenarii), junto con oficiales y artesanos especializados (manuales, ministeriales, magistri). Además, la presencia de seglares en el edificio monástico se intensificaba en aquellos periodos en los que la clausura no se guardaba o era más laxa -principalmente en los siglos bajomedievales,$-{ }^{5}$ frente a otros periodos de mayor observancia; ${ }^{6}$

\footnotetext{
2 Y es que en las tres últimas décadas se pueden contar por cientos las intervenciones arqueológicas realizadas en los monasterios hispanos.

3 Entendemos por extra-claustrales aquellas dependencias que se localizan dentro del recinto monástico, pero por lo común más allá de las pandas que cierran el claustro.

4 En este sentido hay que tener en cuenta que en órdenes como los cistercienses, los cartujos o los franciscanos los trabajos eran soportados en gran medida por los propios monjes, fundamentalmente por los legos o conversos, y donde el protagonismo de los trabajadores laicos fue menor que en otras órdenes.

5 Linage Conde, A. 2007: 12-13. Recordemos también los abarraganamientos de muchos monjes y abades.

6 La familia monástica ha sido bien definida por A. Linage Conde (2007: 50) cuando escribe que "se componía de una parte de las personas relacionadas con el monasterio con una cierta intensidad. Los
}

y pese a su importancia apenas se ha prestado atención a las condiciones vitales y laborales de estos laicos en los monasterios, más si cabe teniendo en cuenta que hace ya tiempo que la familia monástica fue definida desde una perspectiva materialista como una "unidad de producción y consumo". 7

Metodológicamente este trabajo presenta un enfoque heurístico integral, ${ }^{8}$ y pretende además proporcionar una herramienta que permita establecer nuevas preguntas en los procesos de excavación arqueológica de los monasterios peninsulares, contribuyendo a desarrollar los protocolos de intervención en este tipo de yacimientos al incorporar cuestiones -como el análisis de los espacios de trabajo y las infraestructuras- que habitualmente no son tenidas en cuenta. $Y$ es que en muchas ocasiones el enfoque inicial de las investigaciones todavía está fuertemente condicionado por el paradigma de monasterio bellamente petrificado, y la arqueología apenas ha entrado en el análisis de la gestión funcional y laboral de estos espacios religiosos. ${ }^{9}$

Con respecto al marco temporal la revisión se contempla desde un planteamiento diacrónico, entendiendo que los edificios monásticos y las comunidades que los habitaban protagonizaron continuidades entre los tiempos plenomedievales y los modernos, sin apreciarse drásticas interrupciones entre ambas épocas aunque sí considerables transformaciones. En este contexto de larga duración se incardinan los procesos evolutivos de los sistemas estructurales de producción económica así como los cambios coyunturales advenidos de la mano del avance tecnológico, de las reformas institucionales o de las diferentes relaciones socio-laborales vigentes en cada momento. Por estos motivos el periodo de análisis escogido abarca desde la fase de implantación y consolidación del monacato benedictino en la Península Ibérica (siglos XI-XII) hasta las exclaustraciones del xIx.

Haciendo un breve repaso de la historiografía monástica, y más concretamente de la que se ha ocupado del análisis del edificio conventual, hay que señalar que éste ha

monasterios tenían siervos, contrataban asalariados, arrendaban sus tierras a colonos, mantenían o socorrían a personas que habían adquirido ese derecho -una motivación de las donaciones al patrimonio-, además de las ventajas espirituales. A veces, esas relaciones implicaban el ingreso en la familia monástica, por supuesto dándose una franja intermedia de casos y condiciones dudosas".

7 Vid. al respecto las reflexiones de M. Godelier (1973) desde el campo de la antropología, asumidas por S. Moreta Velayos (1974). No obstante no podemos olvidarnos, como escribió Duby, que el consumo de bienes materiales por parte de los monjes estaba en gran parte determinado por la liturgia, Citado en Linage Conde, A. 2007: 23-24.

8 Mediante el cual no solo se contemplen las técnicas analíticas y los métodos de trabajo clásicos de la arqueología, sino que en el proceso de investigación deben de ser incorporadas y manejadas todas aquellas fuentes de información relacionadas con el yacimiento (documentación escrita, antiguas planimetrías, miniaturas, etc.), aplicando una lectura arqueológica sobre las mismas.

9 En buena parte ello ha sido debido a que el análisis de la arquitectura monástica no forma parte de la formación académica habitual de los arqueólogos de gestión, ya que apenas es contemplada en los estudios universitarios de Arqueología o Historia, sino más bien en los de Historia del Arte. 
sido estudiado principalmente desde el punto de vista de su morfología arquitectónica y de la funcionalidad vinculada a la liturgia en general y a cada orden en particular. No es este el lugar para desgranar la amplísima y fructífera bibliografía existente al respecto, encabezada desde los presupuestos teórico-metodológicos de la Historia del Arte, y a la que -descontando algunos trabajos pioneros- la Arqueología se ha incorporado más recientemente, pero en muchas ocasiones se observa una total desconexión entre la historia del señorío económico y la historia del edificio, cuando creemos que es totalmente necesario incardinar la historia del edificio - de su arquitectura- en la historia institucional y económica del monasterio, ya que la capacidad constructiva en un momento determinado se explica en gran medida por la capacidad económica del monasterio; estableciéndose ésta a partir de variables tales como la renta señorial acumulada o el volumen de donaciones recibidas. ${ }^{10}$

En este sentido es sabido que existe una larga tradición entre los historiadores de la documentación escrita en el análisis de los dominios monásticos medievales y su plasmación territorial, ${ }^{11}$ y que ha servido para conocer la orientación económica de estos establecimientos. En paralelo, la estructura económica de los monasterios de época moderna ha sido analizada dentro de un ámbito más general de estudio de las economías señoriales del Antiguo Régimen, ${ }^{12}$ preocupándose particularmente por distinguir las diferentes fuentes de ingreso de renta que disfrutaban, ${ }^{13}$ o si ésta se producía básicamente en especie o en moneda, ${ }^{14}$ lo que ha permitido obtener estimables radiografías de las diferentes clases de productos agrarios que eran custodiados en los almacenes monásticos. ${ }^{15}$ Desafortunadamente

\footnotetext{
10 Vid. por ejemplo las reflexiones de Virgili, A. 2005.

11 Arranca en los años sesenta con un artículo pionero en España -que recoge la tradición de la investigación francesa- de J. GaultierDalche (1965) sobre Santo Toribio de Liébana; tiene el estudio de San Millán de la Cogolla como referente, García de Cortázar, J. A. 1969; y se consolida en los setenta y los ochenta. Sin ánimo de ser sistemáticos nos referimos a trabajos como los de Moreta Velayos, S. 1971; Pallares, Má C. 1979; Mínguez Fernández, J. 1980; García García, E. 1980; o Torrente Fernández, I. 1982. Para el caso concreto del Císter hay que resaltar el trabajo de F. J. Pérez-Embid (1986).

12 Podemos destacar en este sentido los trabajos de Saavedra sobre el monasterio de Carracedo, de E. Llopis Agelán (1980) sobre las economías monásticas al final del Antiguo Régimen en Extremadura, de C. Burgo López (1985) sobre el monasterio benedictino de San Payo de Antealtares, o los de J. Mạ López García (1982) sobre la Cartuja de Na Sra. de Aniago, y (1990) acerca del monasterio de la Santa Espina y el señorío monástico en Castilla. Para el apartado de los conventos urbanos destacan aportaciones como el estudio de S. Gómez Navarro (2010) en el que se analiza la vida cotidiana colectiva en el convento cordobés de Santa Ana durante el primer tercio del siglo XIX a partir de los libros de ingresos y gastos.

13 Por ejemplo explotación directa de carácter agropecuario, protagonismo de los foros y arrendamientos, mayor dependencia de concesiones reales sobre monopolios, etc.

14 Vid. al respecto las aportaciones de Saavedra, P. 1987: 242.

15 Por ejemplo en el siglo XVIII las rentas forales de Carracedo suponían 24,5 fanegas de trigo, 123,5 de centeno, 36,1 de cebada, 58 libras de tocino y 51 gallinas, Saavedra, P. 1987: 245. Por su parte en 1805 el monasterio navarro de La Oliva entre la cosecha propia y otras rentas ingresa $121.000 \mathrm{~kg}$ de trigo, 37.000 de cebada, 55.600 litros de vino,
}

esta información no ha sido tenida en cuenta -salvo algunas excepciones- a la hora de analizar la evolución y organización del edificio monástico ni por parte de los arqueólogos ni de los historiadores del arte.

Y es que aunque la aportación de la arqueología al estudio de la arquitectura monástica ha crecido exponencialmente en los últimos treinta años, ${ }^{16}$ sus principales objetos de estudio también han sido la morfología y la funcionalidad del edificio, prestando especial atención a la iglesia y a las principales dependencias claustrales, con el fin último de definir la fase fundacional y su evolución constructiva posterior. ${ }^{17}$ Un segundo ámbito de la investigación se ha centrado en la caracterización de las fábricas murarias, de las estructuras arquitectónicas, de las cimentaciones, y de todo lo referido a los trabajos previos de acondicionamiento del terreno; aunque todavía está poco desarrollado el análisis de los procesos de petrificación y de las dependencias construidas con materiales perecederos. ${ }^{18}$ Finalmente, otro gran bloque temático de la historiografía de naturaleza arqueológica que se ha ocupado de los recintos monásticos ha sido el estudio de los espacios funerarios, siendo numerosa la producción literaria -aunque escasean las síntesis- que versa sobre los cementerios y el desarrollo de espacios privilegiados de enterramiento en el interior de los monasterios. ${ }^{19}$

3.000 de aceite, 157 corderos que alimentaban a la comunidad y a los criados, Virto Ibáñez, J. J. 1991: 146-47.

16 Una reciente síntesis de la aportación de la arqueología al estudio de los monasterios en España se puede ver en Miguel Hernández, F. 2012.

17 Una buena muestra de esta fecunda línea en la investigación lo constituyen las aportaciones a los diferentes Congresos de Arqueología Medieval y Moderna de Cataluña. Para el primer congreso vid. E. RiuBarrera (1998) para el monasterio de Sant Pere de Rodes; de J. Aguelo et alii (1998a y b) sobre Sant Cugat del Vàlles; y de A. López Mullor y A. Caixal (1998) sobre el monasterio de Sant Llorenç prop Bagà. El II Congreso está dedicado como monográfico a la arqueología de los monasterios catalanes. Específicamente una recopilación de la bibliografía arqueológica dedicada al monacato en Cataluña en Aguelo, J. 2002. Y un estado de la cuestión sobre la arqueología de los monasterios en Cataluña en los años 80 y 90 del siglo xx en Riu-Barrera, 2002. En el III Congreso vid. Subiranas, C. y Vilas, G. 2006 acerca del monasterio de Sant Benet de Bages; de J. López Mullor et alii (2006) de nuevo sobre Sant Llorenç prop Bagà; y de N. Salazar (2006) sobre Santa María de Lavaix.

18 Tenemos un buen ejemplo en las dependencias claustrales de los siglos XV-XVI del convento franciscano-mercedario de Santa María de Raíces en Asturias, Muñiz López, I. y García Álvarez-Busto, A. 2009. Fuera de nuestras fronteras podemos destacar las estructuras de servicio en madera fechadas en el siglo XII en el monasterio benedictino femenino italiano de Santa María de Montescudaio, Baldassarri, M. et alii 2012: 472.

19 El análisis de los panteones, los cementerios y la organización funeraria en los monasterios medievales es un tema de actualidad en la historiografía europea, destacando obras de síntesis como la de R. Gilchrist y C. Sloane (2005) para los monasterios medievales ingleses, o el tomo 56 de la revista Commentarii Cistercienses para el caso concreto de esta orden, Hall. J y Kratzke, C. 2005. En el caso hispano los investigadores se han ocupado principalmente y hasta el momento del estudio de los conjuntos funerarios de la nobleza, y sobre todo de los panteones regios y condales, siendo muy abundante la bibliografía al respecto. Por su parte desde la perspectiva de la arqueología aunque son numerosas las publicaciones sobre excavaciones arqueológicas puntuales se echan en falta revisiones de carácter sintético, bien de las diferentes órdenes monásticas o bien organizadas por periodos de la Edad Media. En este sentido las pioneras revisiones que realizó M. Ríu (1982 y 1989) de las 
Por el contrario el análisis de los espacios de trabajo y de servicio en los recintos monásticos no ha tenido el suficiente calado dentro de nuestras fronteras, sobre todo si lo comparamos con la situación en otros países de la Europa occidental, donde es un buen caldo de cultivo del debate histórico e interpretativo. ${ }^{20}$ Ya a principios de los años ochenta llamaba la atención M. A. García Guinea sobre la situación de retraso de la arqueología monástica en España, ${ }^{21}$ y desde entonces el panorama no ha avanzado todo lo que hubiera sido deseable, más si cabe si lo comparamos con cómo ha progresado en otros campos de estudio -fortificaciones o aldeas por ejemplo-. ${ }^{22}$

En definitivas cuentas resulta notorio que por norma general la historiografía ha construido un paradigma de edificio monástico en el que apenas han sido considerados los espacios de trabajo existentes en el interior del recinto monástico, lo que ha supuesto que la imagen que en la actualidad tenemos de la arquitectura monástica esté fuertemente condicionada por el concepto vitrubiano de venustas, cuando, por el contrario, la investigación demuestra que habitualmente los monasterios eran edificios en obras y en uso, o lo que es lo mismo, inacabados y ajados.

A continuación realizaremos un recorrido por las diferentes estancias e infraestructuras de trabajo existentes en el interior del recinto monástico, permitiéndonos de esta manera entrever aquellos rincones más o menos escondidos donde por lo común trabajaban los legos o los laicos al servicio de la comunidad religiosa, y que desde un punto de vista operativo hemos agrupado en seis ámbitos

necrópolis medievales en Cataluña, entre las que destaca el monográfico dedicado a los cementerios medievales en la revista Acta historica et archaelogica mediaevalia, no han tenido en el resto de la península ibérica la continuidad que hubiera sido deseable.

20 En Inglaterra son representativos los trabajos de Coppack o buena parte de los artículos incluidos en el monográfico dedicado a la arqueología de los monasterios rurales medievales, Gilchrist, R. y Mytum, H. 1989. También en Irlanda se han publicado algunas síntesis sobre el monacato cisterciense que dedican una parte importante de sus contenidos al estudio de los espacios de trabajo y almacenamiento, y con capítulos dedicados ex profeso a las granjas monásticas, Hayter, S. 2013. En Francia es un tema que hace tiempo que ha sido abordado por los estudiosos de los monasterios, sobre todo en lo referido a los monasterios cistercienses, destacando los trabajos de R. Fossier (1949) y más recientemente el coordinado por Léon Pressouyre (1994); y que sigue de actualidad, ya que recientemente la presencia de los laicos en los monasterios franceses entre los siglos V y XII ha sido abordada por S. Bully y C. Sapin, 2013. En Italia cuenta con una tradición historiográfica asentada, destacando -entre los más recientes- trabajos como el dedicado a la bodega monástica de San Michele alla Verruca, Gelichi, S., Alberti, A. y Dadà, M. 2005; también acerca de la gestión de los recursos hídricos en los monasterios altomedievales, Squatriti, 2004; o la ejemplar investigación realizada a propósito de la cocina de S. Vincenzo al Volturno, Carannante et alii, 2004.

21 García Guinea, M. A. 1980.

22 Así todo hay contadas excepciones con respecto a temas específicos, como puede ser el trabajo dedicado por F. Miguel (1989) a los sistemas hidráulicos monásticos, en el que revisa la aportación de la arqueología hasta los años 80 en Europa y España; y más recientemente hay que destacar el XXVIII Seminario sobre Historia del monacato celebrado en Aguilar de Campoo en el verano de 2014 con el título "El ritmo cotidiano de la vida en el monasterio medieval", e inédito cuando redactábamos estas páginas. diferenciados, más un séptimo dedicado a las dependencias que habitaban los propios trabajadores:

1) Espacios productivos agropecuarios (huertos, semilleros, viñedos, cuadras, caballerizas, corrales, gallineros, palomares, pesquerías).

2) Espacios de transformación de la producción agropecuaria (eras, molinos, prensas, almazaras, lagares, hornos, cocinas, panaderías, mataderos, secaderos).

3) Espacios de conservación de la producción agropecuaria (cilleros, hórreos, paneras, cabazos, bodegas, almacenes, pozos de nieve).

4) Espacios asociados a la construcción y mantenimiento del edificio conventual (caleros, tejeras, hornos de fundición, carpinterías, fraguas).

5) Espacios artesanales al servicio de la comunidad claustral (cererías, escritorios).

6) Espacios hidráulicos y calentados al servicio de la comunidad claustral (pozos, norias, aljibes, abastecimientos de agua, letrinas, alcantarillas, baños, lavanderías, calefactorios).

7) Espacios de hábitat de los laicos asociados al servicio de la comunidad claustral (cuartos, viviendas domésticas).

ANÁLISIS ARQUEÓLOGICO DE LOS ESPACIOS PRODUCTIVOS Y DE SERVICIO

\section{Espacios productivos agropecuarios}

Aunque en los grandes monasterios benedictinos y cistercienses los principales espacios dedicados a la producción agropecuaria se encontraban fuera del recinto monástico, ${ }^{23}$ también en las cercanías del edificio conventual -habitualmente intramuros de la tapia que circundaba la reserva más inmediata- se solían localizar otros espacios de cultivo de carácter intensivo o especializado. Es el caso de los huertos, las huertas de invierno ${ }^{24}$ y los semilleros ${ }^{25}$-en muchos casos cerrados con muros de piedra que los protegían de hocicos y pezuñas-, o de los herbolarios asociados a las boticas en los que se cultivaban plantas aromáticas y medicinales. ${ }^{26}$

23 De hecho órdenes como la cisterciense se caracterizan por haber desarrollado un sistema de granjas dependientes de cada monasterio que estaban dedicadas a la producción económica especializada (cerealícola, ganadera, vitivinícola, minera o forestal), Miguel Hernández, F. 2012: 43-44.

24 En el monasterio benedictino de Corias existe una "huerta de invierno", un espacio de cultivo hortícola cercado y bien orientado al sur, situado en las inmediaciones del edificio monástico.

25 En Corias está documentada la existencia en el siglo XVIII de una huerta cerrada con un muro y con una puerta de acceso donde se cultivaban "simientes" de nabo y repollo, García Álvarez-Busto, A. 2011: 387.

26 En el plano de San Gall el jardín de plantas medicinales se dibuja en una esquina del recinto junto a la casa del médico. Por su parte en el monasterio de Corias a mediados del siglo XVIII está documentada una huerta de la botica, cerrada con un muro y donde se cultivaban plantas medicinales, García Álvarez-Busto, A. 2011: 378. En el monasterio de Pedralbes en la época moderna el herbolario se localizaba en el jardín del claustro, Sanjust, C. 2010: 122. Por su parte en el monasterio de Sant Cugat del Vallès está documenta la ampliación a finales del siglo XVIII del recinto amurallado para poder albergar en interior el jardín botánico y la huerta del abad, que contaban con una cisterna de agua para su riego, Artigues, P. 2002. 
Se trata de tierras de cultivo en las que en contadísimos casos se han realizado análisis de pólenes y esporas, pero allí donde sí se han hecho, como en la cartuja de El Paular en Madrid, se han podido identificar las especies cultivadas. ${ }^{27}$ Además, cuando estos espacios han sido estudiados con metodología arqueológica se han documentado evidencias de la acumulación de desechos orgánicos y basureros orientados a la obtención de abono, ${ }^{28}$ mientras que en otros casos la intensidad de los cultivos ha podido ser demostrada al constatarse el empleo de sistemas de regadío abastecidos por norias y pozos. ${ }^{29}$ Estos huertos aparecen ya citados en la regla de San Benito como el lugar donde se obtenían las legumbres para los potajes (pulmentaria), y la mayoría de las veces eran trabajados por sirvientes. ${ }^{30}$

Otros cultivos habituales en las inmediaciones del monasterio eran los viñedos, los árboles frutales -manzanos, castaños-, o las plantaciones de cereales -trigo, cebada-. ${ }^{31}$ Además, el edificio solía estar rodeado de amplias zonas ajardinadas, muy del gusto de la comunidad en sus paseos de retiro, meditación y oración, pero que también fueron diseñados como espacios de recreo y ostentación de los abades. ${ }^{32}$ El registro escrito nos informa de esta preocupación por el ajardinamiento del entorno conventual, ${ }^{33}$ y nuevamente tenemos que destacar la excavación de los jardines de la cartuja de El Paular, donde los análisis polínicos permitieron constatar la existencia de un paseo salpicado de huertas, parterres con plantas ornamentales -crisantemos- y aromáticas -manzanilla- y estanques con fuentes. ${ }^{34}$ En cualquier caso carecemos por el momento en la Península Ibérica de una sólida investigación en lo que se refiere a la organización de estos jardines y espacios de

27 En este caso concreto los análisis polínicos han permitido documentar el cultivo en las huertas de lechugas, alcachofas, rábanos, nabos, coles y escarolas junto con manzanos y perales, Linarejos Cruz, Ma 2006 168.

28 Así se ha podido determinar en el convento de San Gil El Real de Madrid, Martínez Peñarroya, J. 1998: 131.

${ }^{29}$ Es el caso de las huerta de la Cartuja de Sevilla en el siglo XVI, Amores, F. et alii, 1989. O de las huertas del convento de San Francisco en la ciudad de Barcelona, Yarza Luaces, J. 1982: 377. Por su parte en el monasterio portugués de Pombeiro se conoce la existencia en el siglo XVIII dentro de la cerca de varios depósitos de agua alimentados por conducciones que eran empleados para el regadío de las tierras de cultivo existentes dentro del recinto monástico, Mendes Pinto, M. 2011: 168.

${ }_{30} Y$ es que desde el Altomedievo se había descargado a los monjes de su laboreo, aunque en algunas órdenes y congregaciones se mantuvo mucho más presente el trabajo manual de los monjes a lo largo de los siglos -como ocurría entre los cartujos, donde cada celda debía de tener su propio huerto-, Linage Conde, A. 2007: 161.

31 En Corias la plantación de cebada se encontraba cerca de la panadería, García Álvarez-Busto, A. 2011: 386-387.

32 La máxima expresión del tratamiento de los "jardines decorativos" monásticos como espacios de recreo señorial adornados con estanques y fuentes los encontramos en algunas abadías francesas del siglo XVII regidas por abades comendatarios pertenecientes a la alta nobleza, como es el caso de la abadía de Saint-Jean-des-Vignes, Maines, C. y Bondes, S. 1996: 284-88.

33 Empleándose -entre otras especies arbustivas- los setos de boj, como aparece consignado en el monasterio de Corias en el siglo XVIII, García Álvarez-Busto, A. 2011: 388.

34 Linarejos Cruz, Ma 2006: 169-170. En Francia la arqueología monástica ha tenido mayor desarrollo en este sentido, y ha podido documentar los diseños - muchas veces en damero- de los jardines de los monasterios, Pernoud, R. y Herscher, G. 1996. cultivo en el interior de los recintos monásticos, y de cómo y porqué se fueron modificando desde la Edad Media hasta Época Moderna. Un buen ejemplo a seguir en este sentido lo constituye el análisis efectuado en el monasterio de Sao Martinho de Tibaes, donde se ha estudiado la evolución entre el siglo XVI y el XVIII de la distribución de los diferentes espacios existentes dentro de la cerca -huertas, viñas, olivares, árboles frutales, estanques y jardines entre otros-.$^{35}$

Entre las parcelas de cultivo y el edificio religioso se solían ubicar las construcciones dedicadas a la cría y estabulación de la cabaña ganadera. ${ }^{36}$ Estamos hablando de una amplia y diversa tipología arquitectónica que abarca desde sencillos apriscos y cobertizos levantados en madera, ${ }^{37}$ hasta sólidas cuadras edificadas con piedra, mortero y teja. En estos ambientes pecuarios, construidos en buena parte con materiales perecederos, los análisis químicos de los suelos o los estudios palinológicos permitirían identificar acumulaciones de desechos orgánicos o la presencia de algunas especies vegetales específicamente asociadas a la estabulación del ganado, constituyendo técnicas analíticas poco empleadas que deberían contribuir a una mejor interpretación de la gestión de los espacios ganaderos monásticos. Por su parte el estudio de las cuadras y los establos debería resultar más sencillo a priori, en cuanto que se trata de estancias mejor delimitadas en la mayoría de los casos, ${ }^{38}$ pero por el momento no contamos con demasiadas evidencias arqueológicas al respecto, ${ }^{39}$ y aún somos tremendamente deudores de la contada documentación escrita a la hora de reconocer las características edilicias de estas construcciones..$^{40} \mathrm{~A}$ su vez la mayoría de los grandes monasterios tenían en época moderna caballerizas de buena fábrica para los caballos y las mulas -tanto las propias como las de los huéspedes-, que habitualmente se localizaban en el claustro de la hospedería o en un patio de servicio. ${ }^{41}$ En concreto las del monasterio de Corias en el siglo XVIII se encontraban

35 Fontes, L. 2005: 130-158.

36 La ganadería constituyó una parte fundamental de la economía de los monasterios medievales y modernos, y la cabaña ganadera fue empleada como moneda de pago y como fuerza de trabajo, y sus productos derivados comercializados, Virgili, A. 2005: 86-87.

37 De los primeros tenemos un buen ejemplo en el pequeño redil identificado junto al refectorio del monasterio italiano de San Severo a Classe, y en el que un conjunto de hoyos de poste delimitan un recinto cuadrangular que ha sido fechado en la décima centuria, Augenti, A. et alii 2012: 242-43. No obstante la interpretación funcional no es definitiva y los arqueólogos también apuntan la posibilidad de que se tratase de un pequeño cobertizo de herramientas.

38 Sabemos que en Cluny II y III los establos se localizan al sudoeste del recinto claustral configurando edificios alargados, Conant, K. 1968.

39 De los más tempranos es el conjunto documentado en el monasterio altomedieval de Sant Pere de Grau d'Escales, donde junto a las dependencias humanas se localizó una cuadra para ganado mayor junto a otras construcciones y corrales de menor entidad, Padilla Lapuente, I. 1980: 202.

40 Por ejemplo sabemos que en el siglo $x v$ en el monasterio de Pedralbes se había reparado la cubierta del establo empleando haces de cañas y cordel, Sanjust, C. 2010: 154. Además en el siglo XVIII está documentada una corte para los cerdos.

41 En Galicia, por ejemplo, destaca la fábrica de las caballerizas de los monasterio de Oseira, Melón, San Clodio o Sobrado, Blanco Rotea, R. y Fernández Rodríguez, B. 2013. En Asturias, en el monasterio de San Vicente de Oviedo, está constatada la construcción en 1669 de la casa de caballerías, Kawamura, Y. 2005: 197-198. 
divididas internamente en dos huecos principales, uno para las mulas y otro para los bueyes, y eran atendidas por cuatro mozos, guardándose también dentro de ellas las sillas de montar, mantas y demás atalajes. ${ }^{42}$

A través del registro escrito ${ }^{43}$ y del bioarqueológico ${ }^{44}$ tenemos constancia de la existencia de gallineros en los monasterios, y que en la mayoría de los casos se localizaban en el interior del propio recinto. ${ }^{45}$ Asimismo, la cría de palomas por parte de los monjes es una tradición atestiguada desde tiempos medievales, ya que los pichones eran considerados un manjar exclusivo en la mesa de los señores, ${ }^{46} y$ la construcción de los palomares -como la de los hornos y molinos- así como su cría eran consideradas prerrogativas señoriales, ${ }^{47}$ existiendo fuertes cargas punitivas contra los campesinos que las incumplieran. ${ }^{48}$ La edificación de palomares debió de tener su momento de mayor apogeo durante los siglos XVII y XVIII, ${ }^{49}$ reflejando un comportamiento señorial de los abades que también reproduciría la nobleza laica, y por lo general solía tratarse de edificios exentos de planta circular o cuadrada que se encontraban dentro de la cerca que protegía el recinto monástico. ${ }^{50}$

El pescado era otro componente fundamental en la dieta monástica, marcada por los obligatorios periodos de abstinencia -más o menos cumplida- en el consumo de carne. De la preocupación por la obtención de estos recursos piscícolas dan fe las habituales menciones a pesquerías -piscationes- en las cuencas fluviales cercanas a los monasterios. Un estudio de referencia en lo que concierne a su materialidad fue el realizado por I. Padilla en Sant Pere de Grau de Escales, donde se identificó un sistema de remanso del caudal del río mediante la instalación de una presa de madera interrumpiendo la corriente. ${ }^{51}$

42 Las mulas eran empleadas por los monjes en sus frecuentes desplazamientos a otros monasterios y colegios, García Álvarez-Busto, A. 2011: 385.

43 Como es el caso del "caponero" documentado en Corias en e siglo XVIII, Ibídem: 386

44 Los datos ofrecidos por el estudio de los restos faunísticos recuperados en los niveles de los siglos XV y XVI de la Cartuja de Santa María de las Cuevas (Sevilla), que demuestran que gallinas, palomas y perdices eran las aves más consumidas en el convento, Morales Muñiz, A. 1994.

45 En el plano de San Gall aparece dibujado un gallinero, junto a la casa del hortelano y el huerto. También en el monasterio de Pedralbes en época moderna está atestiguado otro, Sanjust, C. 2010: 123.

46 Además la palomina era considerada un apreciado abono para los huertos.

47 Linage Conde, A. 2007: 38.

48 Un estudio de los palomares en el Antiguo Régimen como una prerrogativa exclusivamente señorial en Musset, J. 1984.

49 Vid. para el territorio asturiano el trabajo de Cimadevilla, M. y Prieto Vergara, Mạ A. 2004.

50 Sabemos que en 1709 se acababa de construir en Corias un palomar con paredes de piedra y cal; madera en el suelo, la puerta y la estructura de la cubierta; y tejado de losa y teja, García Álvarez-Busto, A. 2011: 445-46. Un año después, en 1710, se construye un palomar en el monasterio de Matallana de Valladolid, Antón, F. 1942: 320. Por su parte en el monasterio de Oia se conservan dos palomares, una de planta cuadrada y otro circular. Este último fue construido en 1756, Manso Porto, C. 2002: 301 .

51 Padilla Lapuente, I. 1980: 211 y ss. Ya en época moderna sabemos que en el monasterio de Corias se pagaba al "truchero" y a sus ayudantes, los cuales se servían de una red de hilo armada y de estaqueras de madera que cortaban el cauce del río Narcea, García Álvarez-Busto, A. 2011: 387
FIGURA 1

Sistema de remanso del cauce del río documentado junto al monasterio altomedieval de Sant Pere de Grau d'Escales, Padilla, I. 1980: 213.

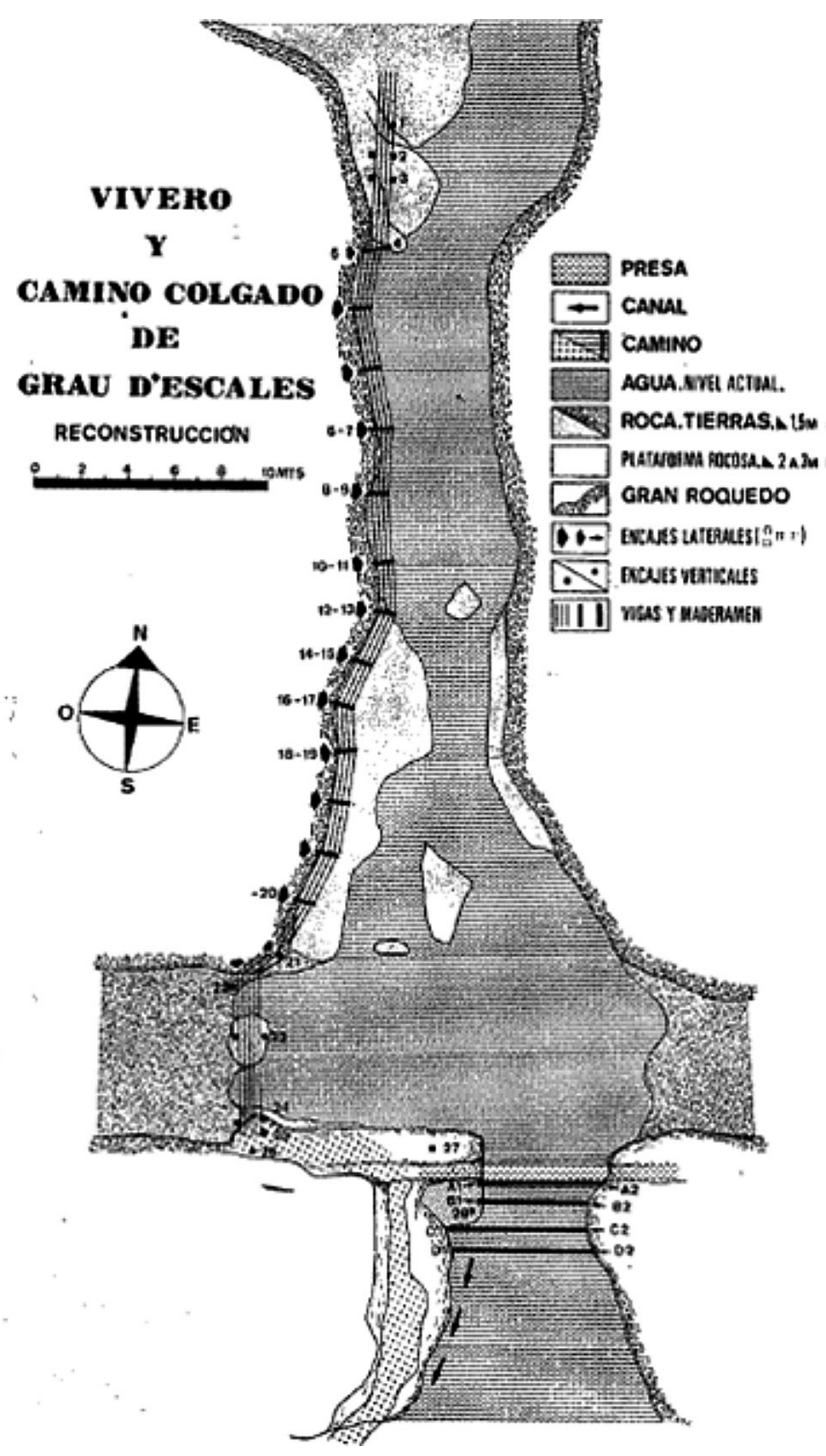

En otros monasterios se conoce la existencia de infraestructuras en la forma de estanques acondicionados como viveros para la cría de peces en el interior del recinto, y que permitían mantener un abastecimiento continuado sin estar sujetos al éxito de la pesca. Si en Inglaterra estas infraestructuras han sido bien estudiadas en los monasterios rurales medievales, ${ }^{52}$ en España los ejemplos que manejamos son ya de época moderna, ${ }^{53}$ y se materializan como pequeñas piscinas resueltas en ladrillo o en mampostería, y alimentadas con conducciones de agua manejadas con compuertas. ${ }^{54}$

52 Vid. al respecto los trabajos de Bond, C. J. 1989 y de Currie, C. K. 1989.

53 Salvo el posible vivero identificado en la cocina medieval del monasterio de Aguilar de Campoo, Matesanz, P. 1993: 105.

54 Como es el caso del monasterio de Yuste en el siglo XVI, Goicolea, J. y Muñoz de San Pedro, G. 1996: 76; del convento franciscano de San Gil el Real, en cuya huerta se documentó una balsa excavada en el terreno que posteriormente se reforma en ladrillo como una alberca con canales de alimentación y desagüe que se alimentaba con el agua de lluvia y la 
Estrechamente vinculados con la explotación de estas pesquerías se encontraban los secaderos de pescado, de los que nos ocuparemos en el siguiente epígrafe dedicado a las estancias e infraestructuras dedicadas a la transformación de los productos agro-ganaderos.

\section{FIGURA 2}

Alberca de época moderna del convento de San Gil el Real, utilizada como posible pesquería, Martínez Peñarroya, J. 1998: 132.

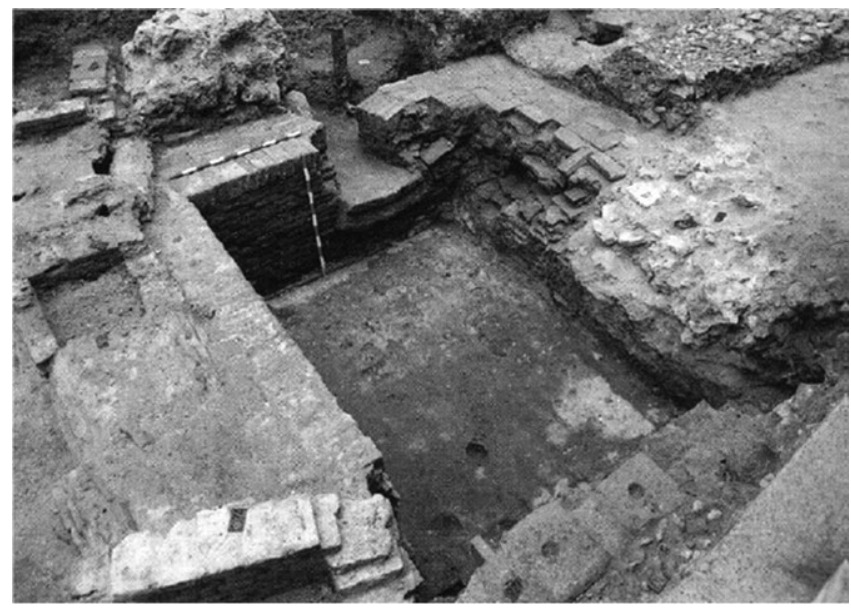

\section{Espacios de transformación de la producción agropecuaria}

En el ciclo de elaboración de los alimentos que consumía y comercializaba la familia monástica se puede distinguir entre una fase primaria y otra secundaria. La primera atiende a la molturación del grano; al prensado de uvas, olivas o manzanas en prensas, lagares o trujales; y al descuartizamiento de los animales; empleándose básicamente para ello la fuerza humana, animal o hidráulica. El segundo tenía lugar entre los lares, hornos y fogones de cocinas y panaderías, donde el fuego recogía el testigo como energía fundamental en el proceso transformador de los comestibles.

El cereal cosechado recibía un primer tratamiento durante el trillado, mediante el cual la paja era separada del grano empleando trillos o mayales. En el monasterio de Ripoll encontramos una de estas eras de trillar dentro del recinto monástico, junto al huerto del abad, los huertos comunes y la plaza del corral donde se alzaba el molino y un granero; ${ }^{55}$ mientras que en el monasterio de Piedra la era se hallaba adosada al exterior del recinto, delante de la puerta fortificada que controlaba el acceso a su interior. ${ }^{56}$

Entre las diferentes construcciones e infraestructuras que permitían la transformación de la cosecha en alimentos destacan por su importancia los molinos, los cuales se encontraban especializados según el producto que tenían

canalización de un arroyo, Martínez Peñarroya, J. 1998: 131; o de los seis estanques del siglo XVIII documentados en la cartuja de El Paular, y que eran alimentados por el río a través de una conducción provista de una compuerta, Linarejos Cruz, Mạ 2006: 167-68.

55 Salazar Ortiz, N. 2010: 549.

56 González Zymla, H. 2010: 70. que triturar. Los más comunes eran los dedicados a la molienda del cereal, y están tan bien documentados en los dominios monásticos que es un lugar común en la historiografía el destacar el interés que demostraron los monasterios por controlar el uso del agua y el proceso de la molienda como medio para fiscalizar la producción campesina. ${ }^{57}$ Pero más allá de los habituales molinos de arroyo de tipología campesina, -de pequeño porte, pocas muelas y ubicados junto a las aldeas-, en las cercanías de los principales monasterios se levantaban otros molinos menos conocidos, y que presentaban una morfología arquitectónica de corte señorial, en ocasiones con soluciones en forma de torre. ${ }^{58}$

FIGURA 3

Molino con tipología de torre situado en la ribera del río Narcea junto al monasterio de Corias. Fue construido entre 1710 y 1711.

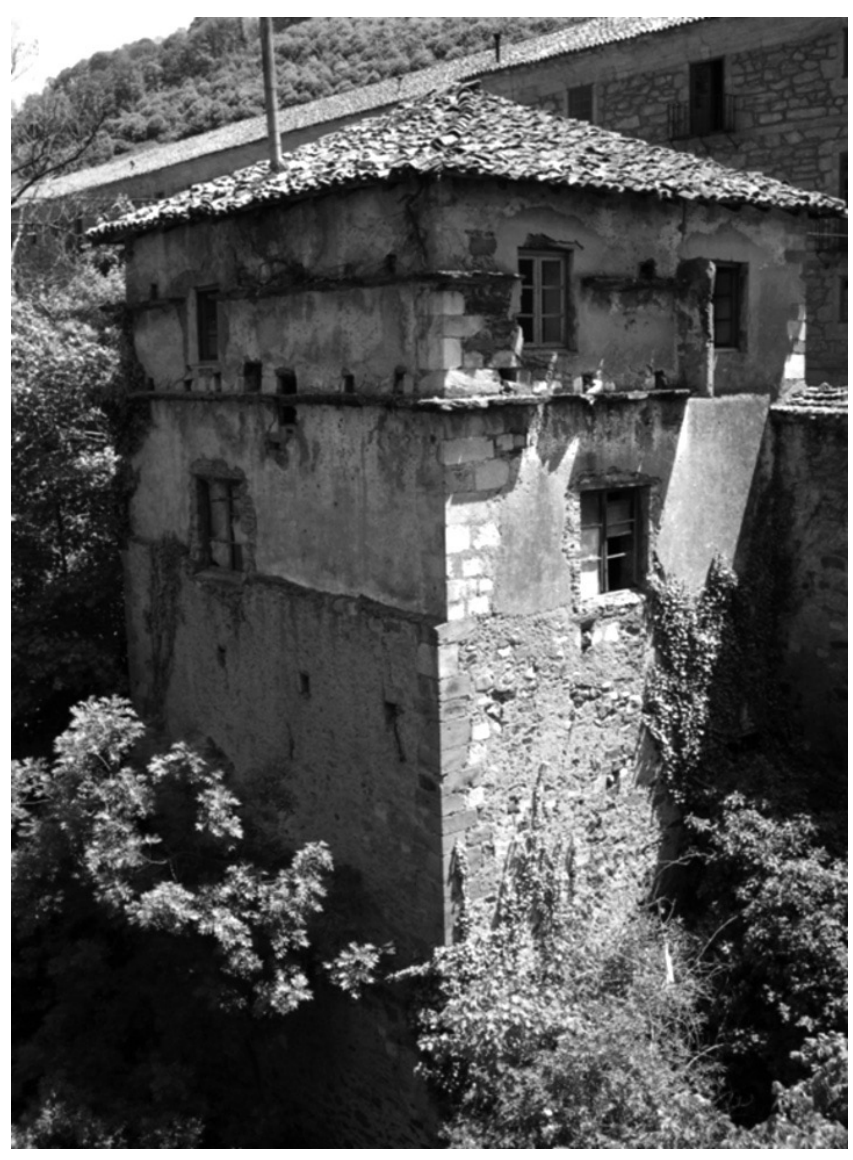

Por su parte frutos como la oliva, la uva, o la manzana eran trasformados mediante el prensado. Para las aceitunas se empleaban las almazaras, que están atestiguadas en algunos monasterios en los siglos medievales y modernos, ${ }^{59}$

57 Virgili, A. 2005: 85-86.

58 Como es el caso del que se construyó en Corias entre 1710 y 1711 , y en cuya planta baja albergaba el rodezno, en la primera la sala de molienda, con dos muelas, y en la segunda estaba coronado por un palomar, García Álvarez-Busto, A. 2011: 435-37.

59 Se conocen en el de Miramar en Mallorca, en el de San Jerónimo en Baza -con una cronología de uso entre los siglos XVI-XVII- o en el de la Valldigna en Valencia, donde se construyó un edificio ex novo para la 
principalmente entre los de la Orden del Císter, ${ }^{60}$ y que se localizaban habitualmente en edificios exentos y funcionaban con energía hidráulica o animal; ${ }^{61}$ mientras que el vino y la sidra se elaboraban en los lagares. Los mejor conocidos son los orientados al prensado de la uva, que solían localizarse junto con las bodegas en claustros secundarios o patios de servicio. ${ }^{62}$ En algunos monasterios además del lagar ubicado en el edificio conventual la comunidad tenía otros lagares-bodega "periféricos" en aquellas poblaciones donde se encontraban sus principales viñedos, facilitando de esta manera la percepción de la cosecha y que ésta no se estropease. Así está constatado por ejemplo en Corias, ${ }^{63}$ en Carracedo ${ }^{64} \mathrm{o}$ en San Pedro de Montes, ${ }^{65}$ aunque existe un enorme desconocimiento sobre la disposición de estas infraestructuras en el terreno y en general sobre la organización productiva de los viñedos monásticos.

Si la obtención de vino o aceite constituían trabajos habituales en los monasterios hispánicos también encontramos referencias a la elaboración de otros productos mucho menos comunes. Así, frente a lo que ocurría en Centroeuropa -donde constituyó una floreciente industria- la elaboración de cerveza presenta en la Península un carácter meramente testimonial, con casos aislados y coyunturales como el del monasterio de Yuste durante la estancia de Carlos I. En otras ocasiones el acceso a los nuevos productos americanos, y el estrecho vínculo que

almazara y la noria situado junto a la puerta de acceso que da paso a la plazuela abierta frente al monasterio. También en la casa trinitaria de Avinganya se documenta la instalación de un molino de aceite en el siglo XVIII en un edificio situado al sur del recinto claustral, en cuyas dependencias anexas a la almazara se localiza un horno y una bodega, y en sus cercanías una galería excavada en la roca aprovechada como fresquera, González, J. R. y Xandri, J. 2002: 56.

60 Molinos hidraúlicos de aceite están documentados en los monasterios de Rueda, Piedra, Poblet, Santes Creus y Vallbona, López López, J. 2012: 190-299.

61 En Portugal conocemos el caso del monasterio de Bustelo, que en el siglo XVIII contaba con un edificio que albergaba los molinos de cereal y dos prensas de aceite, una hidráulica y la otra de tracción animal, Soeiro, T. 1996: 220.

62 Como los de época moderna del monasterio de Valbuena, situado en un edificio del compás de servicio junto a la bodega, García Flores, A. 1999: 298; y de Santa María de Carracedo, ubicado en una panda del claustro de la hospedería enfrente de la bodega, Balado, A y Escribano, C. 2010: 125. En el monasterio de Corias durante la fase neoclásica el lagar se localizaba en el claustro secundario en paralelo a la bodega. Durante la excavación arqueológica del subsuelo de esta sala se localizó la pesa del antiguo llagar, una gran piedra de arenisca de forma tronco-piramidal con unos entalles verticales y un orificio circular en la parte superior que le permitían sujetarse al torno del lagar. También se pudo comprobar cómo originalmente esta dependencia estaba compartimentada en tres salas más pequeñas, cuyos muros medianeros fueron derribados con posterioridad. Es posible, por lo tanto, que la utilización como lagar de esta sala no estuviera prevista de inicio, o que, en un principio, acogiera alguna prensa de menor tamaño y las paredes fueron desmontadas en una segunda fase para acoger el llagar de pesa, que alcanza unas dimensiones considerables. En Asturias se documentan cuatro tipos de llagares. Son los de viga, d'apertón, de sobigañu y el llagar de pesa, que ofrece una presión continua, VV.AA. 2004. En Oia a mediados del XVIII se construyó un nuevo pabellón en el patio de servicios para albergar un lagar para elaborar vino y una bodega, más un horno y una sala aneja, Manso Porto, C. 2002: 293.

63 García Álvarez-Busto, A. 2011: 381-82.

64 Balboa de Paz, J. A. 1997.

65 Durany, M. 1976. algunas órdenes monásticas mantuvieron con sus misiones indianas, favorecieron la difusión de nuevos alimentos como el chocolate en la dieta monástica. En relación con ello sabemos que en Corias en el siglo XVIII la molturación del cacao se realizaba en molinos barquiformes de tipología sudamericana, ${ }^{66}$ y posteriormente se producirá la incorporación de sistemas de mecanización del proceso mediante un molino de chocolate de tracción animal. ${ }^{67}$

\section{FIGURA 4 Y FIGURA 5}

Vestigios del molino de chocolate del monasterio de Corias (siglo XIX). Recreación del funcionamiento del molino de chocolate de Corias (Ilustración de Jesusangel).
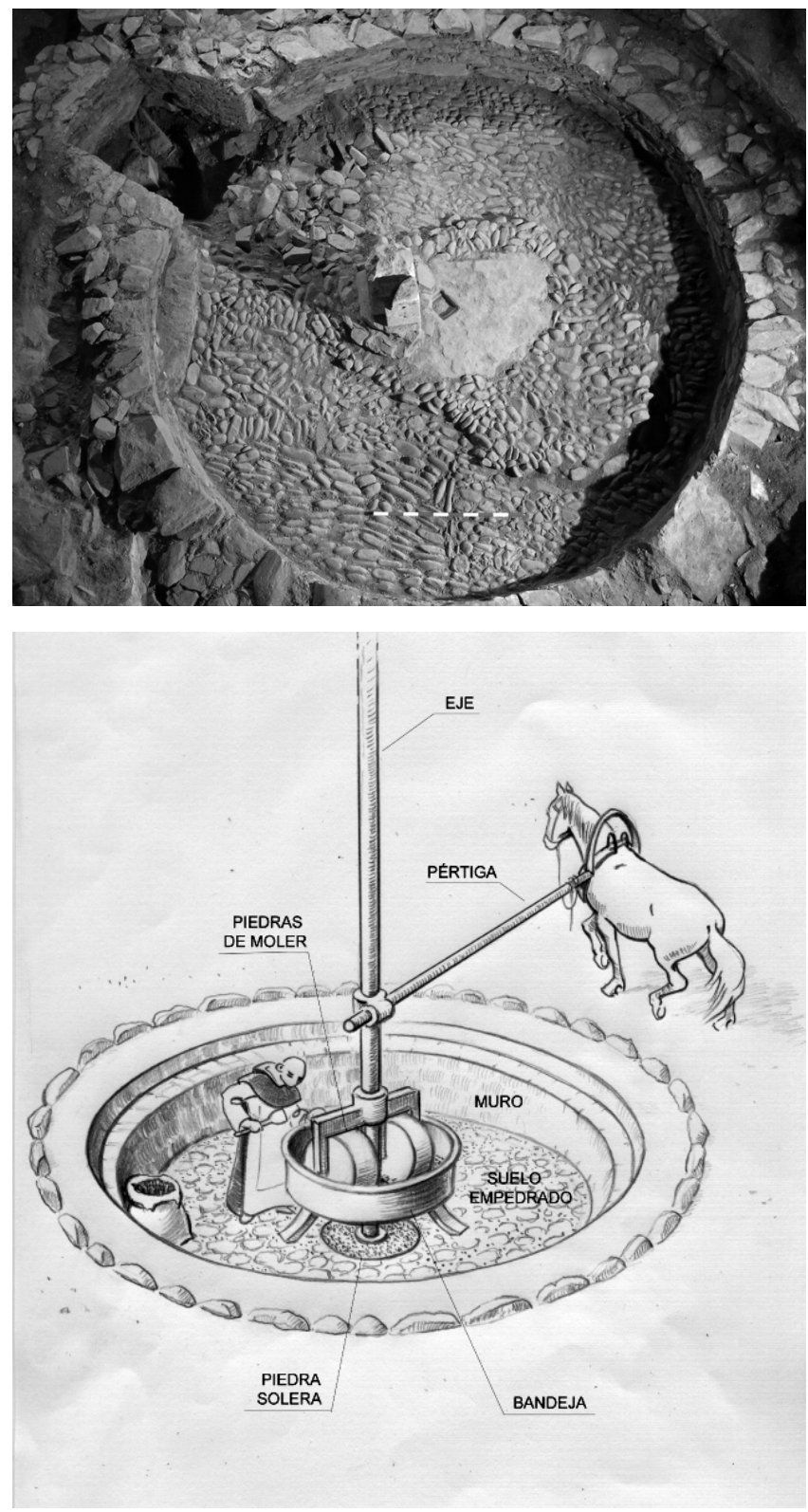

66 Y es que en los fletes marítimos con el grano de cacao también venían los molinos para moltearlo.

67 Instalado por la comunidad dominica que reocupa el edificio después de 1860, García Álvarez-Busto, A. 2013. 
Otras dependencias fundamentales en el funcionamiento de la economía monástica eran el matadero y la carnicería, documentadas ya en el monasterio de Cluny en el siglo XII. ${ }^{68}$ Numerosos estudios arqueofaunísticos han evidenciado el consumo habitual de carne en los monasterios, ${ }^{69}$ y un significativo avance en esta línea de trabajo lo podrían proporcionar los análisis isotópicos realizados en esqueletos sobre grupos diferenciados dentro de la familia monástica (monjes, legos y sirvientes). En cualquier caso es muy poco lo que sabemos más en detalle sobre este tipo de dependencias, que debieron de localizarse en los patios de trabajo, exentas por razones higiénicas, y cerca de puntos de agua dado su uso en abundancia durante la limpieza de las reses sacrificadas. ${ }^{70}$

Una estancia de tratamiento muy poco conocida es el secadero del pescado. De hecho desconocemos su documentación arqueológica en territorio hispano, ${ }^{71}$ aunque sí nos consta su consumo. ${ }^{72}$ La información al respecto es mínima, y gracias a los testimonios escritos sabemos que junto a la Cartuja de Santa María de las Cuevas de Sevilla -pero del otro lado del río- se localizaban las instalaciones donde el pescado era secado y ahumado. ${ }^{73} \mathrm{Si}$ en la época moderna y sobre todo en los grandes monasterios estas labores trataron de alejarse del recinto claustral, dados los malos olores y los humos que provocaban, en algunos monasterios medievales no se constata esta separación física entre el claustro y los espacios de tratamiento primario de los productos. Así ocurre en el monasterio italiano de S. Severo a Classe, donde una estancia situada en el claustro junto al refectorio fue interpretada como un secadero para pescado utilizado en el siglo $x \mathrm{x}^{74}$ La ubicación de esta estancia de trabajo -de la que emanaría un olor desagradable- junto al comedor de los monjes ejemplifica una falta de disociación de los espacios monásticos medievales según su función que sí fue más común durante la época moderna. En cualquier caso el secado de los alimentos -no solo del pescado sino también de frutos, cereales o carnes-, y el empleo de hornos en este proceso, fue un método de

68 Linage Conde, A. 2007: 4.

69 Como el realizado en Cornellana (Asturias), que permite conocer la dieta cárnica consumida en el monasterio medieval, y que estaba encabezada por las ovejas -la mayor parte individuos adultos que debieron de utilizarse para obtener productos secundarios (lana, leche, etc.)y seguida por el grupo de los bóvidos, Adán Álvarez, G. y Álvarez-Lao, D. 2002.

70 En el Corias neoclásico el matadero era un pequeño edificio de planta rectangular que se encontraba exento del conjunto principal y cerca del acueducto y la fuente. En otros monasterios, como el de San Salvador de Oña, el matadero de "las bacas y carneros" también se encontraba separado del edificio conventual, en un patio junto con la casa de los mozos de la labranza, las bodegas, las tinas y los lagares, Barreda, I. 1917: 168.

71 Más frecuentes son las menciones a "pescado seco" en la documentación escrita, como ocurre en la colección medieval del monasterio de Vega (León), Domínguez, S. 2013: 50.

72 Por ejemplo en Corias en el siglo XVIII al pescado seco se le conocía como curadillo, García Álvarez-Busto, A. 2011: 335.

73 Antequera Luengo, J. J. 2012: 16.

74 La excavación del suelo permitió documentar abundantes desechos de pescado en torno a un hogar rodeado de una estructura de madera que servía para sostener los peces, Augenti, A. et alii, 2012: 242. conservación bien conocido en los monasterios que trataremos más adelante.

La fase secundaria del proceso de elaboración de los alimentos se realizaba básicamente en la cocina. Su ubicación más habitual en los monasterios medievales benedictinos y cistercienses era la esquina del claustro situada entre la panda sur -la del refectorio- y la oeste -la de la cilla-, aunque en época moderna también se constatan otras localizaciones menos centralizadas. ${ }^{75}$ También se conocen numerosos establecimientos que contaban con dos cocinas, la mayor y la de los seglares, ${ }^{76}$ o la mayor y la de la enfermería. ${ }^{77}$ Durante la Edad Media y buena parte de la Moderna las cocinas monásticas se encontraban al frente de las cocinas señoriales -por delante de castillos y palacios- en lo que a la preocupación por su ordenación interna y acondicionamiento de infraestructuras se refiere. ${ }^{78}$ Nos estamos refiriendo a cuestiones tales como la disposición de los puntos de fuego, el abastecimiento de agua, la evacuación de los residuos, el mobiliario, los sistemas de luz y ventilación, o la compartimentación interna en estancias diferenciadas -por el tipo de alimentos tratados y almacenados (lácteos, pescados, carne, pan) y según la temperatura (cuartos fríos y calientes)-. Todos ellos son indicadores materiales que nos informan del grado de sofisticación o riqueza que alcanzó cada edificio conventual.

\section{FIGURA 6}

Fogones de la cocina del convento de San Gil el Real, Martínez Peñarroya, J. 1998: 135.

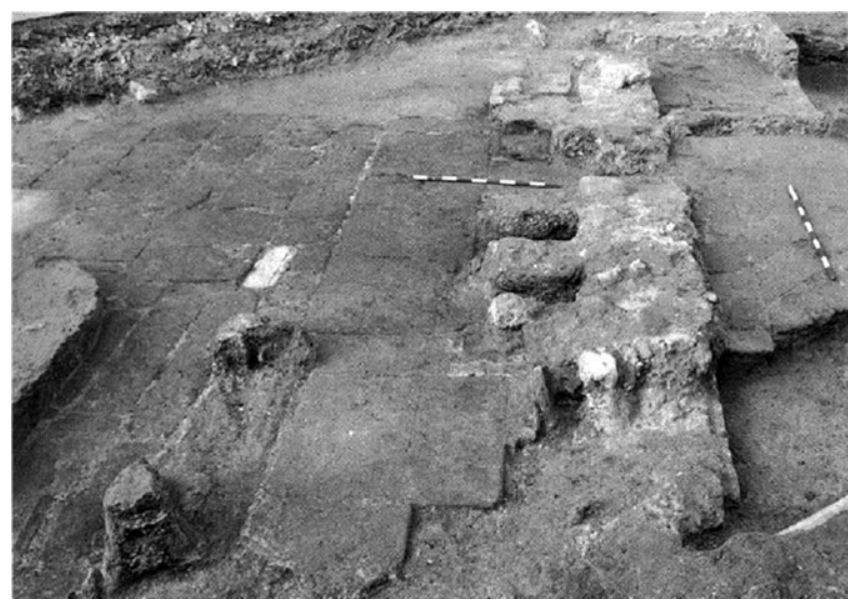

75 Es el caso de la cocina del convento de San Gil El Real, que se situaba en un ala fuera del claustro y en cuyo interior presentaba fogones de obra adosados a la pared oeste y un horno de pan en el centro sobre un pavimento de losas de granito reformado en el siglo XVIII. Este horno está construido mediante la superposición de capas de ladrillo y fragmentos de teja unidos por arcilla, presentando una parrilla formada por baldosas cerámicas cuadradas $(45 \times 45 \mathrm{~cm})$ y una bóveda de ladrillo y arcilla, Martínez Peñarroya, J. 1998: 134.

76 Como ocurría en Cluny II entre finales del siglo x y principios del XI, Linage Conde, A. 2007: 11.

77 Es el caso del monasterio de Pedralbes en los siglos XIV y XV, Sanjust, C. 2010: 143.

78 Abad Zardoya, C. 2010: 94-96. 
FIGURA 7

Horno del convento de San Gil el Real, Martínez Peñarroya, J. 1998: 135.

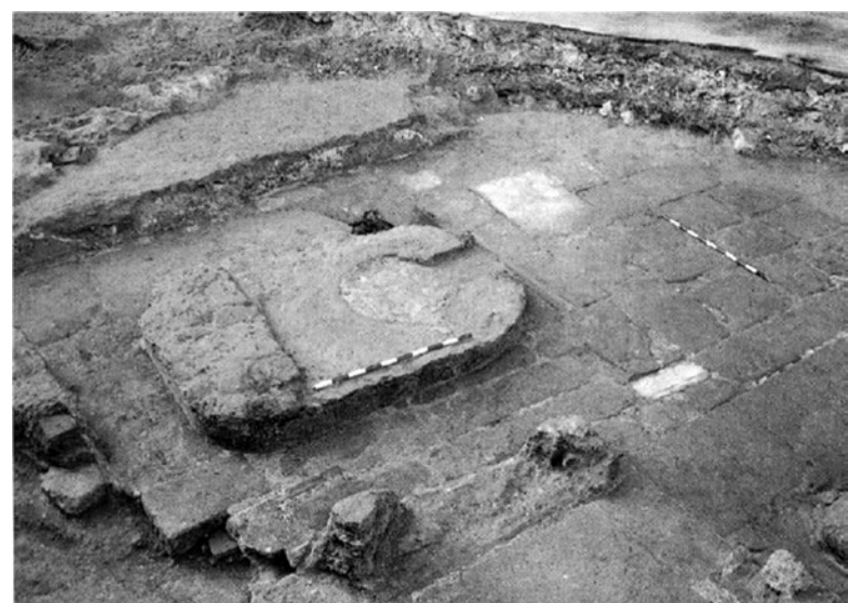

Entre los ejemplos medievales más majestuosos se encuentran las cocinas de los monasterios cistercienses, con hogares centrales cubiertos por grandes campanas abovedadas, ${ }^{79}$ aunque muchas de las que eran más modestas se reformaron completamente durante los siglos XVI y XVII en un contexto general de renovación en estilo renacentista de los edificios conventuales. ${ }^{80}$ Pero cuando la cocina moderna se ubicaba sobre el primigenio espacio que ocupaba la medieval es normal documentar sucesivas reformas y reacondicionamientos, como la sustitución del hogar circular medieval por una chimenea con campana en época moderna. ${ }^{81}$

Si atendemos al conjunto de infraestructuras vinculadas a las necesidades de la cocina una de las fundamentales era el abastecimiento de agua. $Y$ en este sentido las soluciones serán diversas dependiendo de cada monasterio y de cada época. De esta manera hemos podido identificar cocinas con pozo propio; 82 aunque la mayoría de las veces se construyen canalizaciones que conducen el agua desde una fuente cercana, ${ }^{83}$ o que están enganchadas a la acometida general, ${ }^{84} \mathrm{y}$ que abastecen pilones y depósitos de diferentes

79 Como en Santa María la Real de Iranzu o Santa María de Huerta, Abad Castro, C. 1998b: 243-44. Según esta autora la cocina de Huerta fue proyectada en dos fases, correspondiendo a la fase más antigua el hogar central y a la segunda la campana y el abovedamiento. Sobre la cocina propone la ubicación del calefactorio de conversos.

${ }^{80}$ A este periodo corresponde la construcción de un buen número de cocinas monumentales dotadas con grandes chimeneas de campana.

81 Así ocurre en Santa María La Real de Aguilar de Campoo, Matesanz Vera, P. 1993: 102-103; y en otros casos como la abadía cisterciense de Clairefontaine (Luxemburgo) se documenta un fuego central en el siglo XIII que en la centuria siguiente será sustituido por una chimenea de pared, Herremans, D. y Coomans, Th. 2013: 125-126. Durante los siglos XV y XVI la cocina protagonizará sucesivos reacondicionamientos.

82 Como es el caso de la Valldigna en Valencia o de Valbuena en Valladolid, García Flores, A. 1999: 298.

83 En Santa María la Real de Piasca (Cantabria) se documentó una canalización en la cocina que llevaba el agua desde la fuente del monasterio. En esta misma estancia se localizó un posible fogón y una chimenea de horno, Bohigas, R. et alii, 2008: 181.

84 En la Cartuja de Sevilla se documenta un pozo de noria para abastecer a través de atarjeas la cocina. Está fechado en el siglo XV con obras de mantenimiento en el XVII, Amores, F. et alii, 1989: 934. formas y tamaños. ${ }^{85}$ En casos más concretos también está documentada la existencia de pilas de agua y fregaderos alimentados por conducciones hidráulicas, ${ }^{86}$ destacando por su refinamiento la bancada de tres piletas de la cocina de Santes Creus, fechada en el siglo XVI. ${ }^{87}$

El segundo gran grupo de infraestructuras existentes en la coquina monástica es el de las vinculadas al fuego, por lo que nos estamos refiriendo básicamente a los hogares-fogones y a los hornos. Los hogares (lares) se localizan a ras de suelo, bien en el centro de la estancia o junto a una esquina, mientras que los fogones solían disponerse en batería pegados a una de las paredes de la sala. ${ }^{88}$ En este sentido las cocinas monásticas fueran precursoras en el paso del hogar central a ras de suelo a los hogares altos de fábrica adosados a la pared que permitían cocinar erguidos. ${ }^{89}$ Además tanto hogares como fogones solían tener ceniceros asociados donde se almacenaba la ceniza que era aprovechaba para la colada. ${ }^{90}$

Por su parte la presencia del horno en la cocina monástica señorial resulta habitual como lugar especializado en la elaboración de asados y cocidos, y los podemos encontrar exentos, situados en el centro de la sala, ${ }^{91} \mathrm{o}$ abiertos en una de las paredes y dotados con chimeneas para evacuar el humo resueltas mediante una tubería de cerámica encajada en un hueco vertical abierto en la pared. ${ }^{92}$

En cualquier caso la cocina monástica aún no ha sido estudiada por la arqueología española con el grado de detalle que lo ha sido en Italia, resultando ejemplar en este sentido al análisis de la cocina de San Vincenzo al Volturno mediante el registro químico y bioarqueológico, ${ }^{93}$ a partir de los cuales se ha podido determinar la existencia de una "antecocina" destinada a la conservación y preparación preliminar de algunos alimentos - una suerte de despensa donde se almacenaban carne, quesos y embutidos, mientras que los cereales y legumbres se guardaban en el cellarium-; y ya dentro de la propia cocina se pudo identificar un área destinada al

85 En la cocina medieval de Aguilar de Campoo la canalización pasaba por el centro de la cocina y contaba con un acceso con peldaños para la recogida del agua, Matesanz Vera, P. 1993: 102-103. Por su parte en la cocina del siglo XVII de Alcobaça existía un pilón abastecido con agua corriente, Leorux-Dhuys, J. F. 1999: 47.

${ }^{86}$ Como en Pombeiro en el siglo XVII, donde la conducción abastecía tres pilas de piedras (dos grandes y una pequeña), y el agua sucía se evacuaba a través de otro conducto, Mendes Pinto, M. 2011: 164-65; o en Pedralbes en el siglo XVIII, Sanjust, C. 2010: 124.

87 López López, J. 2012: 276.

88 Un buen ejemplo de época moderna de este tipo de fogones lo encontramos en el convento de San Gil el Real, Martínez Peñarroya, J. 1998: 135.

89 Este tipo de fogones se generalizaran en las cocinas laicas urbanas a partir del setecientos, Abad Zardoya, C. 2010: 99-100.

90 Se sabe que los fogones de la cocina monástica medieval de Vega (León) se alimentaban con carbón vegetal elaborado por los carboneros del monasterio, Domínguez, S. 2013: 51.

91 Caso de San Gil el Real, Martínez Peñarroya, J. 1998: 135.

92 Como ocurre en el convento franciscano de Montefrío (Granada) en el siglo XVIII. El horno combina fábrica de ladrillo y sillarejo, su boca se abre en la pared a una altura de 1,30 m con respecto al suelo, y su interior estaba revocado con yeso, Pedregosa, R. y Martínez, A. 2007: 249-253.

93 Los muestreos realizados en el suelo han permitido determinar la dispersión de ácidos grasos, proteínas y fosfatos, y deducir la organización interna y la gestión funcional de los espacios culinarios, demostrando además las posibilidades interpretativas que ofrece la aplicación de las diferentes técnicas analíticas, Carannante, A. et alii, 2008: 494-501. 
tratamiento del pescado y otros productos antes de su cocción, eliminándose los desechos mediante una canalización dispuesta en pendiente hacia el río.

Otros hornos no se localizaban en el interior de las cocinas sino en otras salas claustrales o de los patios de servicio. ${ }^{94}$ La mayoría de las veces se utilizaban para elaborar pan, aunque también conocemos algunos que eran empleados para el secado del maíz ${ }^{95}$ o la cebada ${ }^{96}$ en zonas de clima húmedo, o para cocer la malta. ${ }^{97}$

En algunos casos la panadería se situaba en edificios exentos o anexos al claustro, en alas exteriores, dado el peligro que suponían como posibles focos de incendios. Así, en algunos monasterios las tahonas de época moderna constituían edificios aislados a cierta distancia del patio claustral, ${ }^{98}$ mientras que en otros se encontraban en un cuerpo adosado a uno de los claustros. ${ }^{99}$ Entrando a considerar los detalles interiores sabemos que en Corias en época moderna avanzada la panadería disponía de una sala de trabajo donde se encontraba la boca del horno y en la que se empleaban diferentes utensilios (calderas, cedazos, maseras, cestas o costales), y un cuarto con alcobas de servicio para los trabajadores (un "panadero maior" y tres o cuatro mozos que le asistían). ${ }^{100}$

\section{Espacios de conservación de la producción agropecuaria}

Entre otras muchas cosas los monasterios eran grandes centros productores agrarios y ganaderos, perceptores de renta señorial, y como tal, la despensa constituía una de las estancias fundamentales del edificio monástico. Además, su morfología y sus características constructivas estaban condicionadas por la propia geografía del lugar en el que se localizaba el monasterio y se extendía su patrimonio rústico, lo que determinaba tanto la orientación de la producción como las diferentes características de conservación de los frutos que eran resguardados en las bodegas. Evidentemente todas estas son cuestiones susceptibles de ser analizadas desde un enfoque y una metodología arqueológica, aunque en la práctica no lo hayan sido con la suficiente profundidad. $Y$ es que

94 Es el caso del monasterio benedictino de San Lourenzo de Carboeiro, que presenta un horno en una de las dependencias de claustro y un segundo horno en una edificación anexa del lado norte de la iglesia, Bonilla, A. 2008: 89. En Pedralbes se localiza un horno en la cocina y otro fuera del edificio conventual y adosado al interior del recinto amurallado, Sanjust, C. 2010: 151.

95 Así se ha documentado en alguna granja cisterciense de época medieval en Irlanda, Eogan, G. 2012; Hayter, S. 2013.

96 Así se ha interpretado el granero construido en madera que contaba con un horno documentado en el monasterio altomedieval de Portmahomack (Escocia), Carver, M. 2004: 19-21.

97 Como el documentado en el priorato bajomedieval inglés de Thornholme, Coppack, G. 1989: 207.

98 Así se contata en Caaveiro, Abascal, J. M. y Cebrián, R. 2009: 151; en Pedralbes, Sanjust, C. 2010: 152-153., o en Cornellana, Muñiz López, I. 2001.

99 Como ocurre en Sahagún, Escalona, R. y Pérez, J. 1782: 231.

100 La panadería era conocida como la "casa del horno". Asociada a ella y a sus gastos contables se encontraba un hórreo, García ÁlvarezBusto, A. 2011: 379-380. Por su parte el convento jerónimo de San Lorenzo (México) la panadería contaba con un harinero, un cuarto para los utensilios y otro para la leña. El convento abarca una cronología de los siglos XVI y XVII, Tovar Esquivel, E. 2000: 67. a día de hoy ni siquiera contamos con estudios cuantitativos que den pie a comparar la capacidad de almacenaje (superficie, volumen, sistemas de almacenamiento) de las bodegas y los cilleros monásticos, lo que tampoco nos permite establecer comparaciones entre el comportamiento económico de las diferentes órdenes ni tampoco analizar la evolución de estos espacios entre la época medieval y la moderna.

FIGURA 8 Y FIGURA 9

Cilla del monasterio de Las Huelgas, Burgos. Arquetipo de cilla medieval. Planta baja y piso alto de la cilla, Casas Castells, E. 2005: 139-140.
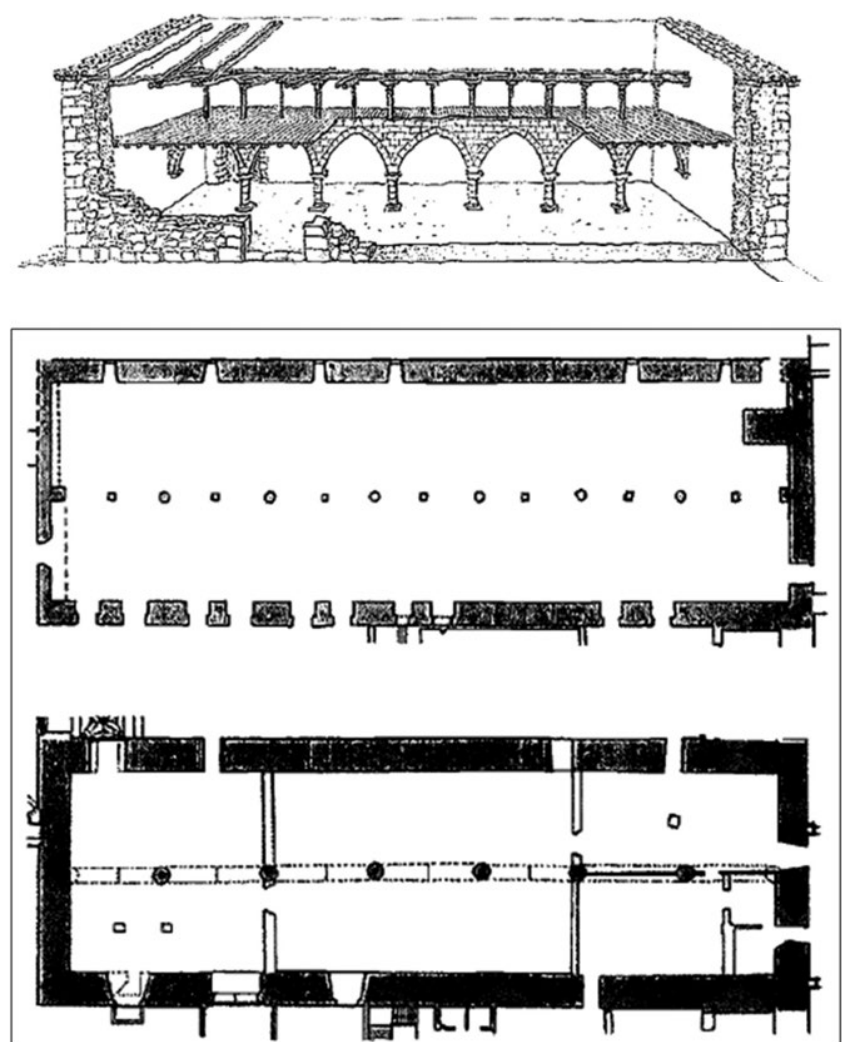

Desde un punto de vista topográfico en la mayoría de los monasterios el cillero se sitúa en la panda occidental del claustro, ${ }^{101}$ tratándose de un espacio de planta rectangular que ocupa buena parte de la crujía, ${ }^{102}$ que en algunas ocasiones presenta dos alturas -diferenciándose los productos que se guardaban en la planta baja y el piso alto-, ${ }^{103}$ y que

101 Así ocurre en edificios de referencia como San Gall o Cluny, y en la mayor parte de los monasterios cistercienses. Para los monasterios cistercienses femeninos vid. Casas Castells, E. 2005. En el monasterio cisterciense italiano medieval de San Michelle alla Verruca la excavación arqueológica definió la panda occidental del claustro con cuatro estancias ocupadas por las despensas de alimentos, Gelichi, S. et alii, 2005: 94-109.

102 Puede ser de nave única o estar dividida por una espina de soportes centrales que reciben las bóvedas o forjados de madera, López de Guereño, Mà T. 1998: 255.

103 En el plano de San Gall se especifica que la planta baja de la cilla cobijaba los toneles mientras que el piso estaba destinado a los alimentos frescos, Bango Torviso, I. 1998c: 159. Para las cillas cistercienses medievales de Las Huelgas (Burgos) y de Santa María de Huerta (Soria) se ha propuesto que la planta baja funcionaría como bodega y la alta como granero, López de Guereño, Mํㅡ. 1998: 255-56. 
suele mostrar buenas fábricas de piedra con cubiertas de teja. ${ }^{104}$

En la mayor parte de la historiografía que versa sobre la arquitectura monástica la cilla se representa como un arquetipo vacío, como un gran contenedor sin nada que contener. De esta manera, apenas sabemos nada sobre cómo se guardaba el grano en su interior, y en qué medida se empleaban contenedores cerámicos para almacenar el grano, o más bien sacos o cestería de tejidos vegetales, o arcas y cajones de madera. Desconocemos en definitiva buena parte de los sistemas de almacenamiento monásticos, y es en este punto donde la arqueología debería aportar una mayor y mejor documentación.

\section{FIGURA 10}

Bodega medieval con grandes tinajas cerámicas empleadas como contenedores en la Cartuja de El Paular en Madrid, Miguel Hernández, F. 2012: 46.

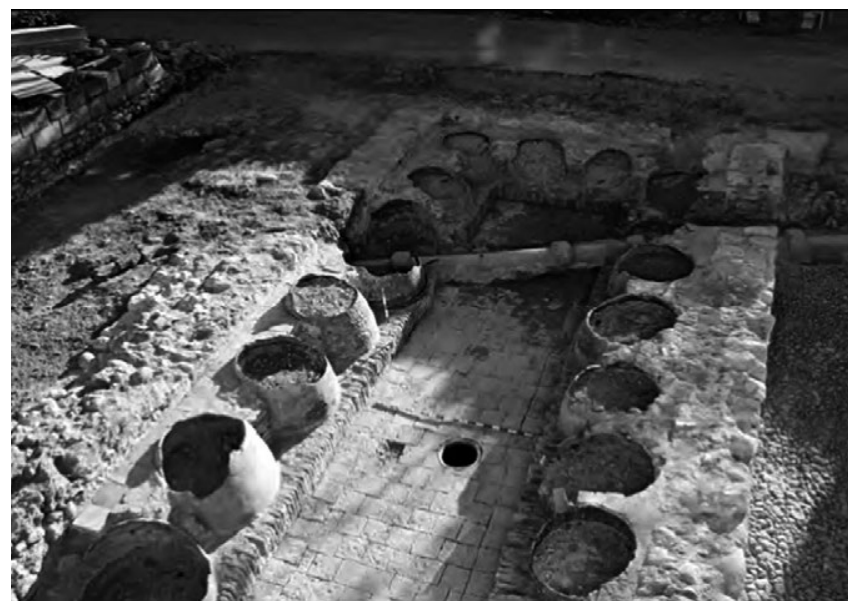

Sabemos además que algunos cilleros de época moderna contaban con puertas que permitían el acceso a mulas y carros al interior de la planta baja, habitualmente desde un patio de servicio colindante, ${ }^{105}$ y que en los vanos de acceso se podían disponer rampas para facilitar la entrada de los productos. ${ }^{106}$ En ciertos casos se observa la existencia de tolvas por donde se introducía el grano desde el exterior, ${ }^{107} \mathrm{o}$ para traspasar el grano del piso superior al inferior, ${ }^{108}$ y tam-

104 Contamos con un buen ejemplo de la construcción de una cilla medieval en un monasterio benedictino en el contrato de obra de 1196 entre el abad del monasterio de San Román de Entrepeñas y fray Martín, quien se comprometía a edificar "el sobrado desde la pared de la iglesia hasta la cocina, y la bodega de abajo y los trojes. Puertas y ventanas de cal y canto, las paredes de argamasa, madera y zarzos y la cubierta de tejas", Bango Torviso, I. 1994: 37-38; López de Guereño, Mạ T. 1998: 255 nota 6.

105 Como ocurre en el monasterio de San Andrés de Arroyo, López de Guereño, Mạ T. 1998: 256; Casas Castells, E. 2005: 138.

106 Por ejemplo en el monasterio cisterciense de Fitero, Olcoz, S. 2008: 168 .

107 Como se documenta en el monasterio premonstratense de San Salvador de Urdax (Navarra) en la cilla del siglo XVII, López de Guereño, Mà T. 1996: 45.

108 Por ejemplo en la cilla de Las Huelgas de Burgos, López de Guereño, Mạ T. 1998: 263. bién se conocen sistemas de ventilación mediante ventanas saeteras que permitían una aireación más o menos controlada del interior empleando contras de madera.

Aunque evidentemente existieron graneros medievales de buena fábrica desconocemos cuándo se produce y con qué ritmos se desarrolla el proceso de petrificación de la cilla. En muchos monasterios la panda del cillero no se cierra hasta la Baja Edad Media y antes podía haber estructuras resueltas mediante pabellones de madera. ${ }^{109}$ En España también desconocemos cómo y cuándo se produce el tránsito -cuando éste tuvo lugar, que no siempre- entre las cillas de madera y los grandes almacenes de piedra. En cualquier caso en la esencia misma de la economía monástica se encontraba el procurarse de graneros capaces y adecuados, ya que sobre ellos orbitaba buena parte de la función señorial de la comunidad claustral. ${ }^{110} \mathrm{Y}$ es que un buen almacén permitía hacer frente a los periodos de carestía con mayor solvencia, y no pocas veces los monasterios actuaron como prestamistas con las familias campesinas aquejadas por hambrunas y malas cosechas, sirviendo las tierras de éstas como medio de cobro ante sus frecuentes impagos. ${ }^{111}$

Más allá de lo poco que sabemos para la Edad Media el análisis de la arquitectura monástica demuestra que en época moderna se amplió considerablemente la capacidad de almacenaje de muchos monasterios mediante la construcción de nuevos recintos claustrales en el siglo XVI, ${ }^{112}$ y de patios de servicio en los siglos XVII y XVIII que tenían amplios graneros en sus plantas bajas. ${ }^{113}$

109 En Irlanda la arqueología ha permitido comprobar cómo buena parte de los graneros medievales en los monasterios cistercienses estaban construidos con postes madera de roble dispuestos sobre zócalos de mampostería, Hayter, S. 2013. En el caso concreto del granero de Bective los análisis carpológicos llegaron a determinar que el $96 \%$ de los microrrestos estudiados pertenecían a granos, con un $64 \%$ de trigo y un $34 \%$ de avena, Lyons, S. 2012.

110 Aunque una parte de la renta monástica en grano podía ser entregada en otros cilleros monásticos periféricos buena parte tenía que ser entregada en el cillero central del propio monasterio. Así está constatado en el monasterio de Santa María de la Oliva en época medieval: "e luego que todos los seysanta e cinco cafizes de trigo fueren mesurados sin tarda ninguna, que vos, el dicho concello de los lavradores de Melida sin otra tarda ninguna, que con vuestras bestias e con vuestros sacos e a vuestra propia mession, que nos lo trayades e pongades dentro del granero e en el dicho nuestro monasterio, cada anno de aquí adelant por todos tiempos del mundo, e que nos seades tenidos de mesurarlo otra vegada, sino poner e descargarlo dentro del dicho granero del monasterio segunt que vinieren las bestias", Munita Lonaiz, J. A. 1995: 513.

111 Asimismo podía darse el caso de que la panera del monasterio fuera la única que podía prestar grano al campesino para la siembra. Así está documentado por ejemplo en la Cartuja de Aniago de Valladolid, López García, J. M. 1982: 113.

112 La reforma de los edificios monásticos en el siglo XVı tuvo mucho que ver con la reforma institucional que protagonizan los monasterios a lo largo de la centuria, alejándolos de los usos impuestos en las dos centurias anteriores por los abades comendatarios y la nobleza encomendera. Para el caso de los monasterios benedictinos gallegos vid. Fernández Cortizo, C. 2005.

113 Son numerosísimos los ejemplos por lo que aquí tan solo haremos una breve reseña de algunos de ellos. Ocurre así en el monasterio cisterciense de Oia, donde está documentada la construcción de graneros y una nueva bodega entre 1668 y 1681, Manso Porto, C. 2002: 289. También en Santa María la Real entre los siglos XVII y XVIII se construye un patio de servicio que alojaba los nuevos almacenes, la panera, el molino y las cuadras. Por su parte en el monasterio de Santa María de Melón, en el nuevo claustro de servicio edificado en el primer cuarto del 


\section{FIGURA 11 Y FIGURA 12}

Vista de la panera oriental (granero) del claustro de la hospedería del monasterio de Santa María de Melón (Orense). A la izquierda se aprecia la fábrica original del primer cuarto del s. XVII, con bóveda de cañón de sillería. A la derecha se aprecia la reforma funcional acometida en este espacio con la instalación de una lagar de uva en el tercer cuarto del siglo XVIII,

Blanco Rotea, R. y Fernández Rodríguez, B. 2013.
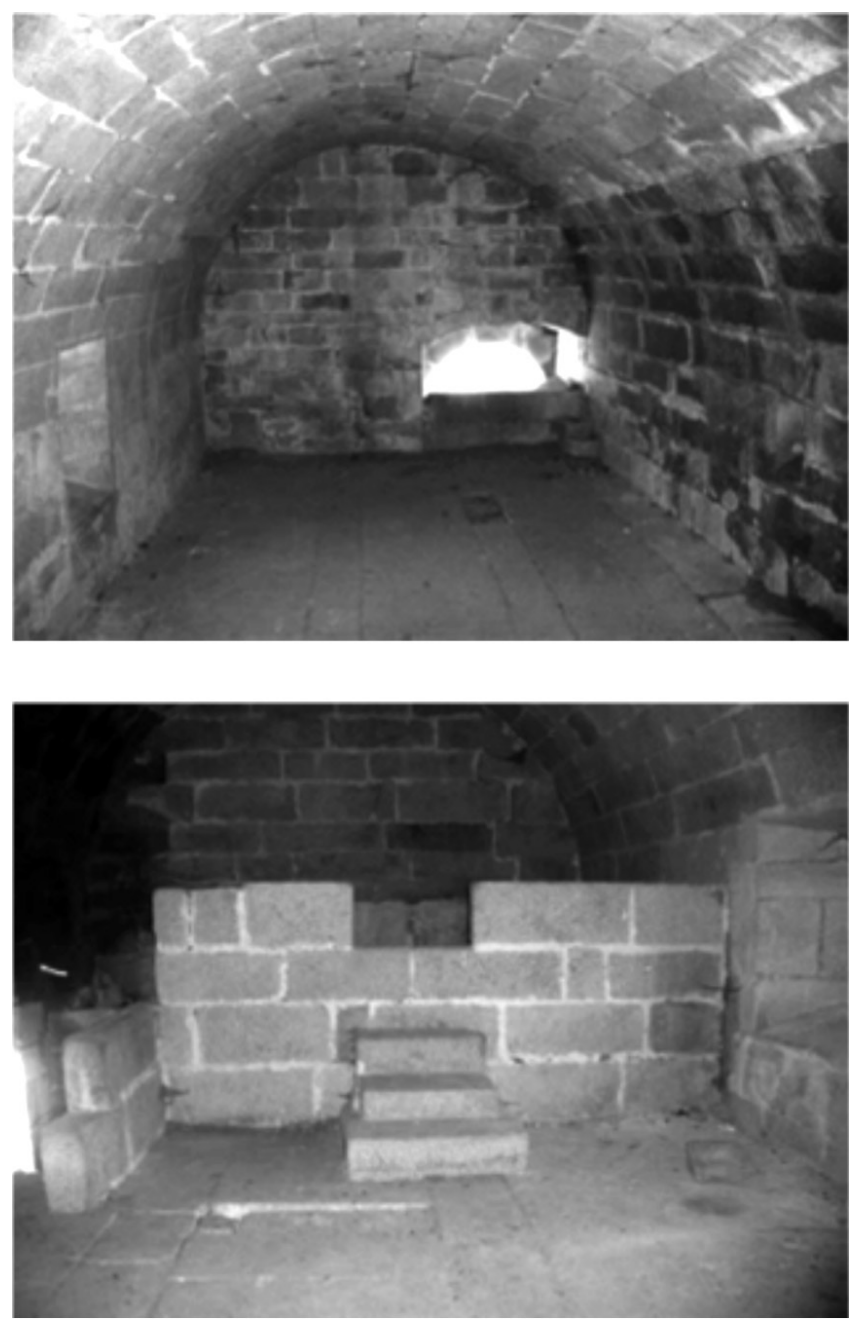

Un ejemplo paradigmático es Cornellana, con su plazuela del granero y su plazuela de la leña a cada lado del claustro procesional central. En este caso las excavaciones arqueológicas han permitido documentar la construcción de sistemas de drenaje en el subsuelo del nuevo granero mediante la disposición de potentes rellenos de cantos rodados sobre los limos de la vega fluvial que actuaban como cámara de aire que mejoraban las condiciones de conservación de

siglo XVII, se disponen dos grandes estancias rectangulares -las paneras- que servían para guardar el grano. Ambas presentan una magnifica fábrica de sillares con bóveda de cañón, documentándose en el suelo reformas mediante el recrecido de la cota del enlosado con el propósito de contrarrestar la humedad propia del terreno. Una de las dos paneras, la oriental, sufrirá un cambio de función en el tercer cuarto del siglo XVIII, al acoger en su interior el lagar de uva tras la ruina de la anterior bodega, Blanco Rotea, R. y Fernández Rodríguez, B. 2013: 62-65. los productos. ${ }^{114}$ Esta preocupación por aislar la cosecha de la humedad también se constata en otros monasterios de época moderna mediante el recrecido en altura de los pavimentos, ${ }^{115}$ o la creación de cámaras huecas de aire bajo el suelo. ${ }^{116}$

Esta ampliación de la capacidad de almacenaje de los monasterios en época moderna debió de estar vinculada en gran medida a la consolidación de las rentas agrarias procedentes de la explotación indirecta (foros y arriendos) y los pagos en especie, principalmente en cereal, ${ }^{117}$ aunque estos procesos todavía no están suficientemente analizados en lo que se refiere al reflejo arquitectónico que tuvieron.

Además de la panera central ubicada en el edificio monástico, donde se recaudaban las rentas de las poblaciones más cercanas, los monasterios tenían otras paneras en prioratos, granjas o aldeas más alejadas donde concentraban sus propiedades. ${ }^{118}$ Asimismo hay que tener en cuenta que el monasterio comercializaba el cereal y el vino, lo que le permitía monetizar la producción agraria, ${ }^{119}$ y que buena parte de la cosecha almacenada era vendida en el mismo año, promoviéndose la puesta en circulación del grano, ${ }^{120}$ por lo que en definitiva los cilleros monásticos funcionaban como grandes centros de almacenamiento y redistribución de lo producido. ${ }^{121}$

Junto a la cilla de recia fábrica de cal y canto el grano también podía ser almacenado en construcciones exentas del tipo de los hórreos, paneras y cabazos. Conocemos su existencia en numerosos monasterios gracias a la documentación escrita y también a la miniatura, ${ }^{122}$ aunque no se sabe con exactitud la distribución geográfica que alcanzaron durante la época medieval y moderna. ${ }^{123}$ En ocasiones los

114 A partir de la intervención arqueológica se pudo deducir que el patio de servicios oriental, conocido como plazuela del granero, fue construido entre la segunda mitad del siglo XVII y la primera del XVIII, García Álvarez-Busto, A. y Adán Álvarez, G. 2001.

115 Como en el monasterio ourensano de Santa María de Melón, Blanco Rotea, R. y Fernández Rodríguez, B. 2013: 62-65.

116 Así se puede verificar en el cillero del monasterio portugués de Santa María de Pombeiro.

117 En Galicia los monasterios cistercienses recibían el pago en especie sobre todo en centeno y mijo (entre ambos más de un $80 \%$ ), seguido del maíz, cuya introducción supuso un considerable impacto en la producción agraria, Seijas, M. 2012: 441.

118 Para el caso de los monasterios gallegos del Císter ha sido estudiado por M. Seijas (Ibídem: 447).

119 También el monasterio podía hacer pagos en especie en sus compras de tierras y otras propiedades inmuebles. Así está documentado durante el siglo XIII y XIV en el monasterio navarro de La Oliva, que empleaba en sus pagos trigo y cebada, Munita Loinaz, J. A. 1995: 195.

120 En este sentido se ha propuesto para el caso del monasterio de Carracedo en el siglo XVIII, lo que supondría que se propiciaría que buena parte del grano pasase poco tiempo almacenado, Saavedra, P. 1987: 255-56.

121 Así se ha determinado para los monasterios medievales ingleses, Bond, C. J. 2001, e italianos, Gelichi, S. et alii, 2005.

122 En San Millán de la Cogolla, en Santa Fe de Navarra, o en San Juan Bautista de Poio por ejemplo. Por su parte en las Cantigas de Alfonso X aparecen representados unos hórreos llenos de grano en el monasterio de Monte Sión de Jerusalén, aunque el miniaturista parece estar representado la tipología de estas construcciones propia del noroeste de la península ibérica, Menéndez Pidal, G. 1986: 115.

${ }_{123}$ Un buen ejemplo sobre su empleo lo constituye el pequeño monasterio asturiano de Santa María de Villamayor (siglos XVI-XVII), donde sabemos que alrededor de la iglesia había varias casas, un hórreo y una panera, junto con las huertas, todo ello cerrado con una cerca 
horrea abaciales no se encontraban en el propio monasterio sino en aquellas aldeas campesinas donde se concentraban propiedades del dominio monástico. ${ }^{124}$

\section{FIGURA 13}

Cabazo de época moderna del monasterio de San Juan Bautista de Poio (foto: J. A. Fernández de Córdoba Pérez).

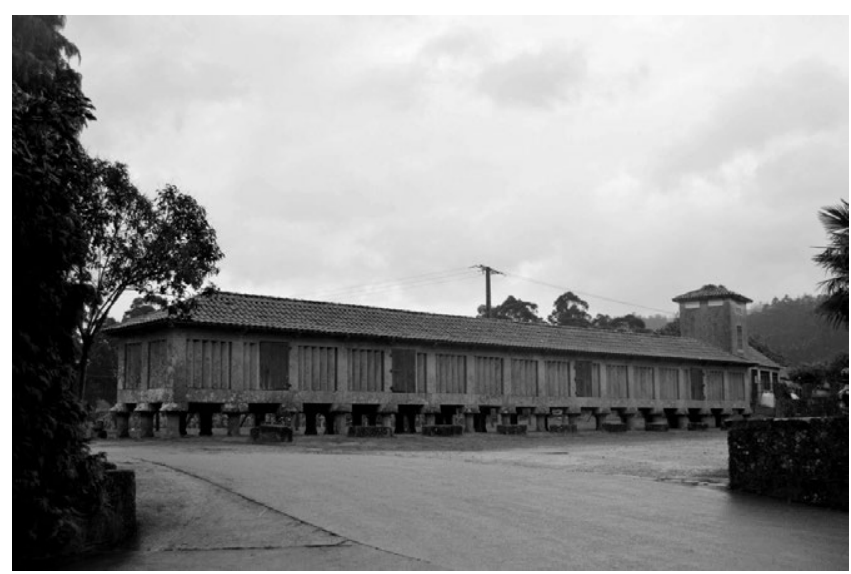

FIGURA 14

Representación de hórreos en las Cantigas de Alfonso X (Cant. 187b), Menéndez Pidal, G. 1986: 115.

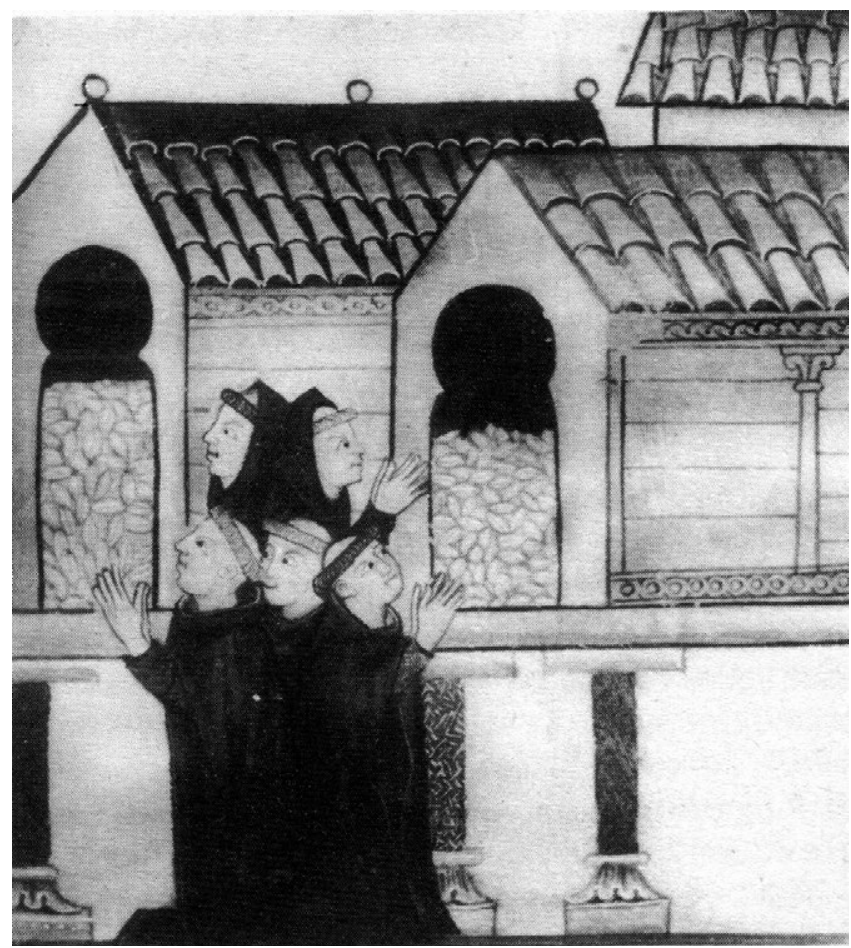

en cuya puerta estaba el molino de la cocina, Martínez Vega, A. 1997: 34. También la documentación escrita evidencia una preocupación por el mantenimiento de este tipo de graneros, como se constata en Santa María de Obona, donde se contratará la sustitución de la "panera viexa" por una nueva durante las obras de renovación del claustro en 1658, Sanz Fuentes, Mạ J. y Buría Fernández, Ma J. 2002: 86.

124 Así ocurre con el monasterio cisterciense navarro de La Oliva en el siglo XII, que tenía su hórreo en la cercana población de Carcastillo y donde los campesinos debían entregar la cuarta parte de las décimas que les correspondían, Virto Ibáñez, A. 1991: 146.
Por otra parte, y principalmente en los grandes monasterios, se puede diferenciar entre la despensa, inmediata a la cocina, y el cillero-almacén, de mayor superficie y capacidad, empleado como granero, y que solía ubicarse en la panda occidental del claustro o en los patios de servicio. ${ }^{125}$ En estas despensas monásticas se guardaban derivados lácteos o cárnicos como el queso y el tocino, ${ }^{126}$ y su aprovisionamiento era tan substancial que había un monje encargado de ello, el coquinarius o culinarius, diferenciado del hermano mayordomo o cillerero al cargo del granero. ${ }^{127}$

También conocemos otras despensas especializadas según los productos que almacenaban, como las fruterías, ${ }^{128}$ o las vinagreras. ${ }^{129}$ Además del vinagre la sal y el hielo eran productos clave a la hora de conservar los alimentos y, aunque no se ha hecho, la ubicación de los saleros podría deducirse mediante análisis químicos de los suelos. En algunos monasterios se constata la existencia de despensas especializadas destinadas a preservar el pescado fresco o en salazón. ${ }^{130}$ Por su parte el hielo era empleado para conservar los alimentos y los portes de pescado, ${ }^{131}$ pero también para preparar bebidas frías y con fines terapéuticos. ${ }^{132}$ Destaca el pozo de hielo, también conocido como "casa de la nieve", conservado en el recinto exterior del monasterio de Poblet, ${ }^{133}$ mientras que en otros casos como San Jerónimo en Zamora o Nuestra Señora de la Victoria en Salamanca la probable presencia de pozos de nieve todavía tiene que ser verificada arqueológicamente.

Una marcada especialización en la preservación de los alimentos la presentan los almacenes subterráneos, tanto en lo que se refiere a la existencia de bodegas de fábrica

125 En el monasterio de Villanueva de Oscos en un inventario de 1572 de las dependencias monásticas se distingue entre la despensa, la bodega, la panera y la cillerecía, Álvarez Castrillón, J. A. 2009.

126 Conocemos una descripción del siglo XVI de la despensa del monasterio de Monsalud: "Ay un arca grande para tener pan, y otras dos para provision, y otras dos pequennas que ay en el refitorio. Ytem, un peso con sus pesas para pesar pan, que son una arroba y media arroba y quatro libras. Ytem, ay quatro toçinos y medio", Díaz Ibáñez, J. 1995: 467. También sabemos que cuando en 1808 las tropas francesas saquean en el monasterio navarro de La Oliva se llevaron, entre otros productos, 20 piezas de tocino y 89 arrobas de queso, Virto lbáñez, A. 1991: 149.

127 Linage Conde, A. 2007: 68.

128 En Corias en el edificio neoclásico existía una sala del claustro principal que era empleada como frutería, García Álvarez-Busto, A. 2011: 533.

129 Que en el siglo XVIII se localizaba junto a la cocina en el monasterio de Melón, Blanco Rotea, R. y Fernández Rodríguez, B. 2013. El vinagre también era empleado en las enfermerías monásticas como antiséptico para las heridas, Cunha Leal, C. y Almeida Ferreira, M. 2006: 97.

130 En Corias está documentada la existencia en el siglo XVIII de un chafariz cercano a la cocina, cerrado con candado, y donde se conservaba el pescado salado a remojo, García Álvarez-Busto, A. 2011: 334. También en la cartuja sevillana de Santa María de las Cuevas la cocina disponía en el siglo XVII de varias despensas para almacenar pescado fresco y en salazón, además de albañales para el lavado y eliminación de los desechos, Antequera Luengo, J. J. 2012: 17

131 Así está constado entre los puertos asturianos y el monasterio de Corias, García Álvarez-Busto, A. 2011.

132 Moro, J. Ma 1976: 651.

133 Se trata de una construcción subterránea de planta circular construida en 1748, y que está cubierta con una bóveda hemiesférica en la que se localiza una apertura de acceso y trabajo, López López, J. 2012: 253-54. 
como de cuevas excavadas en la roca, conociéndose varios ejemplos de cada una de ellas, algunas de época medieval, ${ }^{134}$ y la mayoría modernas. Entre éstas las podemos encontrar dispuestas en sótanos bajo las cocinas, ${ }^{135}$ o subterráneas y reforzadas con bóvedas de ladrillo acondicionadas con hornacinas para albergar los recipientes de almacenaje. ${ }^{136}$

\section{FIGURA 15}

Detalle de las bodegas subterráneas de San Gil El Real, Martínez Peñarroya, 1998: 134.

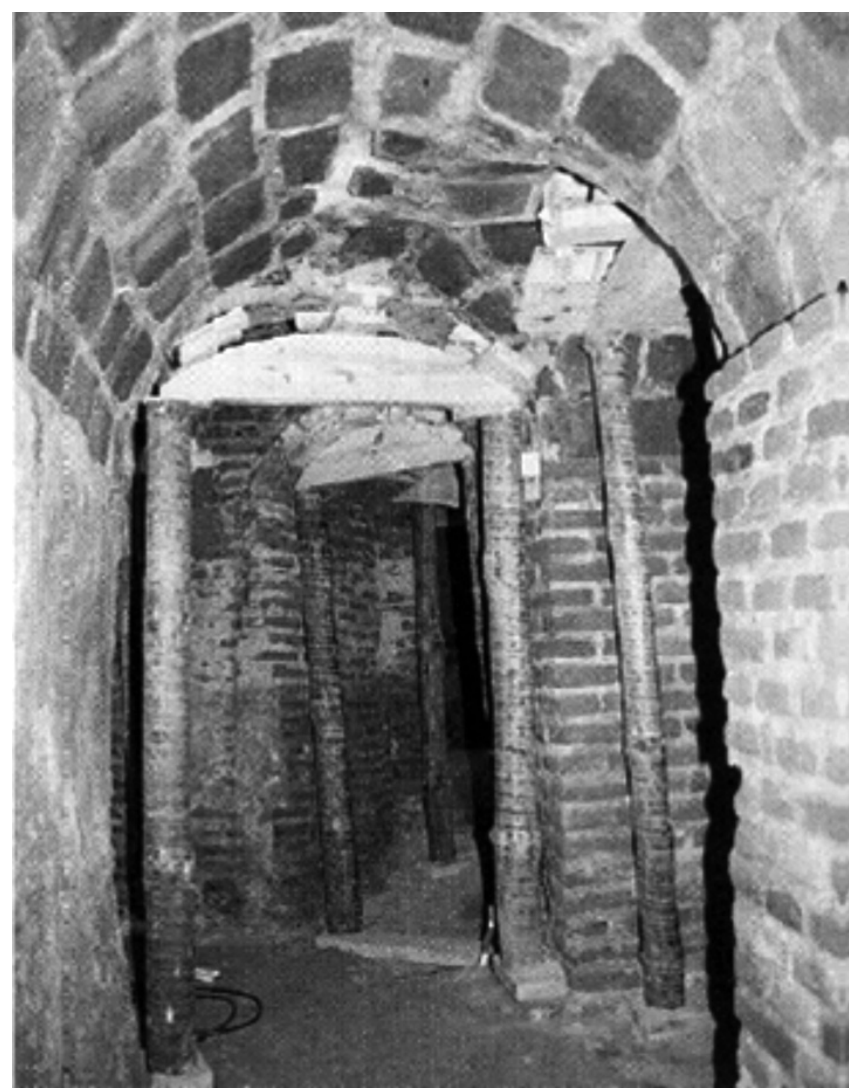

134 Así, en el convento de San Clemente de Toledo se documentaron unos sótanos cerca del refectorio con función de almacenaje y probable cronología medieval, Rodríguez Untoria, S. y Fernández del Cerro, J. 2011: 23.

135 Así, en el convento de Carmelitas Descalzas de Barcelona -fundado a finales del siglo XVI- se constata una particular disposición de la cocina y la despensa en dos cuerpos verticales situados en un ala de servicio anexa al claustro. La cocina se localizaba en la planta del claustro, y bajo ella se encontraba la despensa subterránea. Entre ambas había un hueco de comunicación abierto en la bóveda, y la despensa también contaba con un acceso directo desde la huerta del convento, Busquets, C. y Pastor, I. 2002: 150.

136 En San Gil el Real se localizan unas bodegas subterráneas bajo la galería norte del claustro, cerca de las cocinas, que avanzado el siglo XVII sustituyeron a otras anteriores, también subterráneas y que tras su abandono se aprovecharon como basurero. Presentan obra revestida de ladrillo con bóvedas de cañón y cúpulas en las intersecciones, donde se disponían una serie de hornacinas, Martínez Peñarroya, J. 1998: 133. Por su parte en el convento de La Merced de Ciudad Real (siglos XVII-XVIII) al norte del claustro se documentó un pequeño sótano comunicado con una cueva excavada en la roca, y en cuyo interior hay una serie de nichos entre pilares que albergaban las tinajas y los recipientes para los alimentos, sirviendo de despensa de la cocina. Según los autores en esta despensa se almacenaban alimentos como aceite, agua, azúcar, carne, chocolate, huevos o leche, Martín, P. y Aranda, A. 2007: 214.

\section{FIGURA 16}

Cilla del monasterio de Las Huelgas, Burgos. Arquetipo de cilla medieval. Planta baja y piso alto de la cilla, Casas Castells, E. 2005: 139-140.

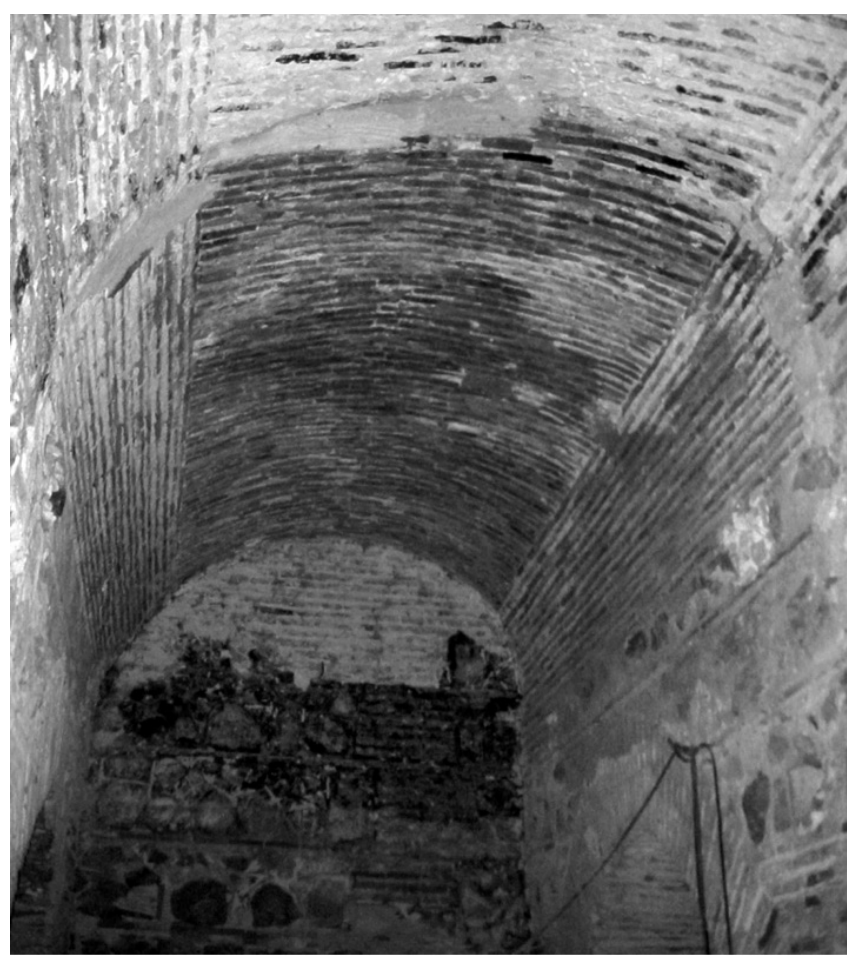

Y es que allí donde el terreno podía ser horadado este tipo de bodegas permitía mejorar notablemente las condiciones de conservación de algunos alimentos, al ofrecer una temperatura constante-inferior a la del exterior buena parte del año-, ausencia de luz, mejor aislamiento frente a ciertos animales e insectos, un ambiente fresco y mejores condiciones que los silos. En la documentación escrita aparecen consignadas como fresqueras, que podían ser subterráneas pero también ocupar alguna sala del edificio, orientada al norte normalmente. Estas bodegas eran óptimas para conservar la carne, el pescado o los huevos frescos por el verano, y en ellas se podían guardar vasijas con carnes adobadas o pescado curado en sal, vinagre o aceite. ${ }^{137}$

También el vino se mantenía mejor en bodegas subterráneas, como demuestra la amplia tradición constatada en numerosos lugares de la Península Ibérica, con ejemplos representativos en Aranda de Duero o en Hita. Éste suponía un pilar fundamental en la vida de los monasterios, no solo por su marcado cariz litúrgico, sino también por su valor como alimento, como instrumento de atención hospitalaria, como medio de pago por los trabajos, como elemento de transacción comercial y obtención de ingresos

137 Vid. al respecto las reflexiones de Cantos Rueda, A. 2007. En el monasterio de Pedralbes se documenta en época moderna una bodega que servía para almacenar entre otros productos aceite, y que además contaba con una canalización que permitía evacuar las aguas residuales, enganchada al complejo sistema de saneamiento general del edificio, Sanjust, C. 2010: 122. 
monetarios, ${ }^{138}$ y en definitiva como símbolo de riqueza y poder de los estamentos señoriales. ${ }^{139}$

En las bodegas para el vino también hay que diferenciar entre las que se encontraban integradas en el edificio conventual y las que estaban excavadas en el terreno. ${ }^{140}$ De las primeras tenemos ejemplos tan bien preservados como las románicas de San Pedro de Cardeña y Valbuena, o la gótica de San Benet de Bages. ${ }^{141}$ Por su parte en el monasterio de Guadalupe había varias bodegas, algunas verdaderamente espaciosas y que conocemos a través de la visita de Jerónimo Münzer en el siglo xv, por lo que sabemos que para el vino tinto se utilizaban toneles y para el vino blanco y el vinagre tinajas, mientras que en las labores de trasiego se empleaban jarros de cobre y botas y odres de cuero. ${ }^{142}$ Las bodegas necesitaban de considerables trabajos de mantenimiento y limpieza, principalmente de las cubas, por lo que eran uno de los espacios de trabajo monásticos que requerían un mayor número de trabajadores.

Para época moderna contamos con datos del monasterio de Corias, en el cual la bodega se dispone en un sótano excavado en la roca situado en la panda oriental del claustro secundario justo enfrente del lagar, ${ }^{143}$ y donde la producción de vino tenía una importancia nuclear en la economía doméstica, ya que las cántaras se empleaban para el pago de muchos de los servicios contratados (portes, compra de cal, de madera, etc.). Por esta razón era fundamental controlar el acceso a la bodega mediante una puerta cerrada bajo candado y llave en manos del custos vini. No obstante hay que tener en cuenta que con el genérico nombre de "bodegas" también se incluían los almacenes donde se guardaba la leña cortada, tan necesaria por otra parte como combustible en los hornos y la cocina. ${ }^{144}$

138 Monetizando la renta en especie. Para este fin algunos monasterios contaban con almacenes en las ciudades administrados por religiosos y orientados a la venta del vino, como era el caso de la Cartuja de Aniago en Valladolid, López García, J. Ma 1982: 101.

139 Vid. al respecto las reflexiones de Cerro Herranz, Mạ F. y Sánchez Rubio, Ma A. 1984: 95-96.

140 La proliferación de este tipo de bodegas-túnel excavadas en la roca se ha propuesto para los siglos XVI, XVII Y XVIII, Nuño González, J. 2008: 18.

141 Una construcción semi-subterránea con arcos transversales al eje longitudinal fechada en el siglo XIV.

142 "primeramente nos llevaron a una inmensa bodega cavada en el monte, donde vimos ingentes cubas y tinajas llenas de vino y luego otras dos que no eran menos grandes (...) El Monasterio posee hermosas cuevas donde guardan el vino (...) en verano tienen el vino muy frío y en invierno están calientes", La bodega del monasterio contaba a finales del siglo xv con 179 cubas, Cerro Herranz, Mạ F. y Sánchez Rubio, Mạ A 1984: 103-105.

143 A principio del siglo XVIII en Corias el vino se conservaba en cubas de madera y para su trasiego se empleaban odres de piel. También en Pedralbes la bodega del vino se localizaba en el sótano, Sanjust, C. 2010: 151.

144 Sabemos que en Corias en un año se podían almacenar más de 400 carros de leña que los jornaleros bajaban por el río hasta el monasterio, García Álvarez-Busto, A. 2011: 383. Y en Pedralbes en los siglos XV y XVı había un edificio cercano a la cocina que era conocido como la "casa de la fusta" que servía como almacén de la madera, Sanjust, 2010, p. 153. Por su parte en Cornellana uno de los patios de servicio de época moderna era conocido con el expresivo término de "plazuela de la leña".

\section{Espacios asociados a la construcción o mantenimiento del edificio}

Dentro del conjunto de espacios de trabajo orientados a la construcción y mantenimiento del edificio monástico se puede diferenciar entre los que presentan un carácter más coyuntural, determinados por la necesidades específicas y concretas de la obra, ${ }^{145}$ y aquellos otros que encierran un sentido más estructural, formando parte de la esencia misma del complejo monástico al orientarse fundamentalmente al mantenimiento del edificio.

Entre estos espacios se encuentran las tejeras, que pueden encontrarse en ambos grupos, ya que algunas -al igual que los caleros-se instalaban a pie de obra para satisfacer una demanda puntual durante la construcción del edificio monástico, ${ }^{146}$ aunque lo más habitual es que se recurriese a la adquisición de tejas en los centros de producción existentes al uso, e incluso algunos monasterios llegaron a tener tejeras en propiedad. ${ }^{147}$

Por su parte los caleros no siempre estaban vinculados a la construcción del edificio monástico, ya que en algunas granjas cistercienses irlandesas de época medieval se han documentado este tipo de hornos destinados a la producción de cal para el abonado de los campos, ${ }^{148}$ lo que estaría estrechamente relacionado con el propósito de intensificar el rendimiento de los cultivos. En el caso del Escorial el propio arquitecto Juan Bautista de Toledo había proyectado en 1562 la construcción de cuatro hornos de cal en las inmediaciones del edificio que abasteciesen de cal a la obra, pero ante la fuerte demanda requerida enseguida se hizo necesario comprar cal en algunos hornos situados en los pueblos del entorno. ${ }^{149}$ También tendría un carácter coyuntural el calero documentado en Corias, ${ }^{150}$ donde la estratigrafía documentada refleja la repetición de las hornadas. ${ }^{151}$ Resulta significativo que este calero medieval se ubicase a pie de obra -aunque fuera del recinto nuclear-, por lo que habría que

145 Un ejemplo precioso de estas instalaciones industriales de carácter coyuntural al servicio de la construcción de la obra monástica se documentó en la excavación del monasterio altomedieval de San Vincenzo al Volturno, donde se documentó un horno para fabricar tejas y baldosas, una fosa de fundición de campanas, un taller de vidrio para las lámparas que iluminarían el edificio, y una cuba para elaborar la argamasa. Todas estas instalaciones fueron desmanteladas y selladas cuando se acabaron las obras. Por el contrario existía un taller colectivo de carácter estructural orientado a la producción de objetos suntuarios (orfebrería, metalistería de cobre y hierro, y vidrio), Mitchell, J. 1996: 148-154.

146 Un horno para fabricar tejas y baldosas cerámicas se documentó en el subsuelo del monasterio altomedieval de San Vincenzo al Volturno, Ibidem: 143-144.

147 Como ocurre en el monasterio cisterciense de La Oliva (Navarra), que tenía en 1805 un horno para cocer teja y ladrillo en la cercana población campesina de Carcastillo. El monasterio contaba además con era de trillar, lagares, molino de aceite, graneros y caballerizas, Virto Ibáñez, A. 1991: 145.

148 Hayter, S. 2013: 21.

149 Muñoz Jiménez, J. M. y Schnell Quiertant, P. 2006: 77.

150 Se encuentra vinculado a la fase de obra románica de la segunda mitad del siglo XII y primera del XIII. Presenta una estructura muy sencilla en forma de cubeta de fondo cóncavo semi-excavada en la terraza fluvial.

151 Con unas capas de carbón generadas por las sucesivas cargas de combustible, unas capas de ceniza de cal formadas por la quema y fracturación de la piedra caliza, y unas capas de desecho que responden al cierre de una hornada y el acondicionamiento del fondo del horno para la siguiente, García Álvarez-Busto, A. 2011: 151. 
trasladar hasta el monasterio la piedra caliza extraída de las canteras; mientras que por el contrario la documentación escrita nos informa que en el siglo XVIII los hornos de cal se localizaban en aquellos lugares en los que existían afloramientos de caliza, transportándose al monasterio la cal ya elaborada. ${ }^{152}$ A su vez en el edificio neoclásico construido en 1774 había una estancia en la planta baja del claustro secundario que era conocida como el "quarto de la cal". La excavación arqueológica en esta sala permitió documentar los depósitos de cal, resueltos mediante tres piletas rectangulares dispuestas en paralelo y construidas con tabiques de ladrillo macizo trabado con argamasa, ${ }^{153}$ y que permitían asegurar un stock de una materia prima tan empleada en las pequeñas obras de mantenimiento del edificio. ${ }^{154}$ También en la Andalucía dieciochesca se conocen otros monasterios que contaban con depósitos de cal y yeso. ${ }^{155}$

\section{FIGURA 17}

Horno de cal del siglo XII documentado en el monasterio de Corias. Se encuentra vinculado a la gran reforma románica del establecimiento.

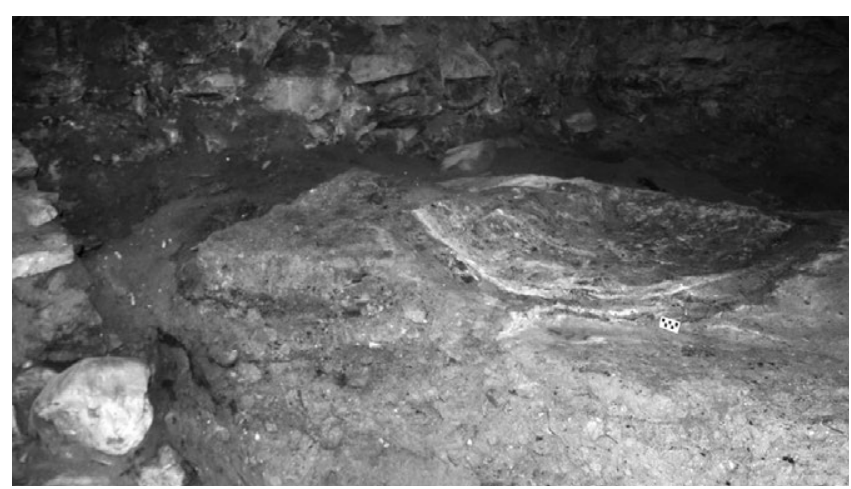

FIGURA 18

Depósitos de cal localizados en el quarto de la cal del monasterio neoclásico de Corias (1774-1835).

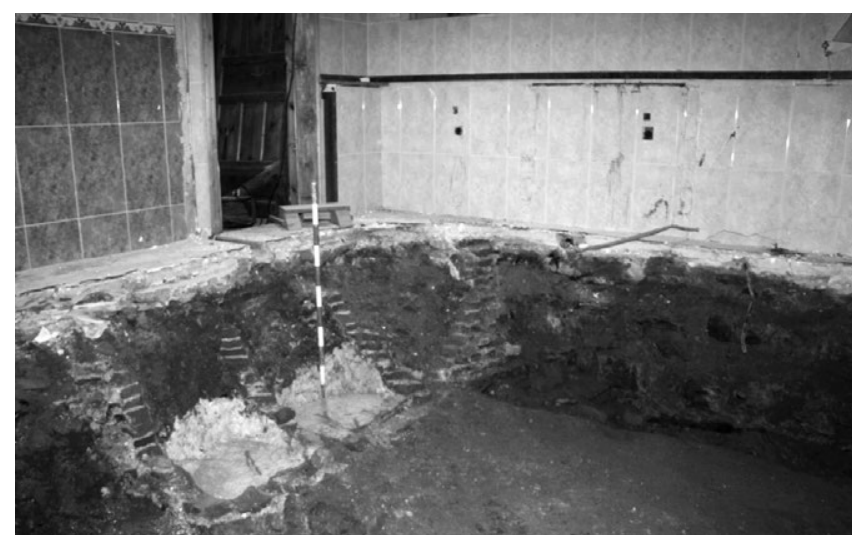

152 Y es que a principios del siglo XVIII en Corias no había calero, y la cal era adquirida bien en piedra bien como cal viva, Ibidem: 397.

153 En el fondo todavía se conservaba una capa de cal de unos 20 $\mathrm{cm}$. de grosor.

154 García Álvarez-Busto, A. 2011: 534. En otras ocasiones este tipo de piletas de cal parecen tener un carácter más coyuntural, asociadas a la construcción del edificio, como parece ser el caso de las documentadas en el subsuelo de la iglesia de San Pedro de la Rúa de Estella (Navarra), García Gazólaz, J. et alii, 2011: 195.

155 Vid. al respecto Florido Trujillo, G. 1996.
Otro tipo de estructuras bastante habituales en el subsuelo monástico son las fosas de fundición de campanas de bronce. Aunque se conocen ejemplos anteriores, ${ }^{156}$ buena parte de ellas se datan entre los siglos XIII y XV, y se deben a la mano de maestros fundidores itinerantes que se desplazaban de monasterio en monasterio. Estas fosas se suelen documentar en las cercanías de los campanarios, ${ }^{157}$ y no pocas veces en el interior mismo de las iglesias. ${ }^{158}$ Desde luego uno de los yacimientos más ricos y más complejos al respecto es el monasterio portugués de Santa María de Pombeiro, donde se documentaron hasta cuatro fosas de fundir campanas de cronología bajomedieval. ${ }^{159}$ Por su parte durante la época moderna se constata la pervivencia de maestros que se desplazaban a los monasterios y continuaban fundiendo a pie de campanario, ${ }^{160}$ pero también la adquisición de las campanas ya fabricadas en talleres estables que trabajaban en los arrabales de las ciudades. ${ }^{161}$

\section{FIGURA 19}

Fosa de fundición de campanas documentada en el convento de San Francisco de Avilés (2 a mitad siglo XIII), Ríos González, S. 2014: 216.

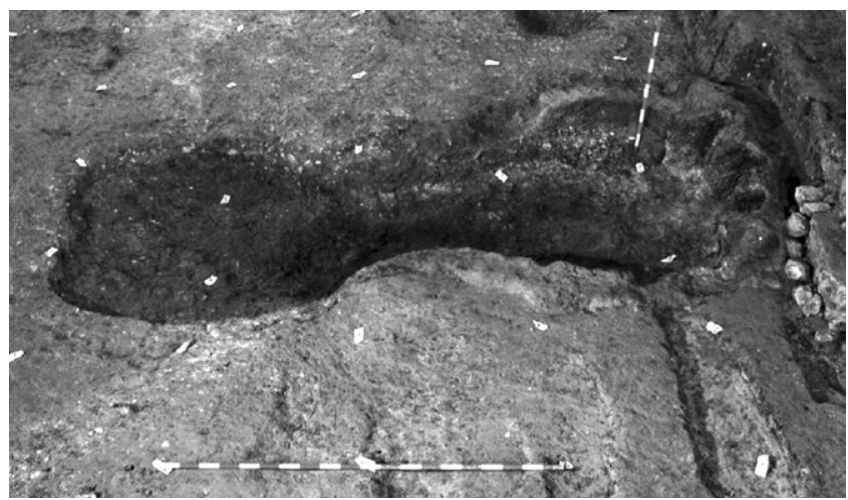

156 Una fosa de fundición de campanas se documentó en las excavaciones del monasterio altomedieval de San Vicenzo al Volturno, Mitchell, J. 1996: 145-46.

157 Un buen ejemplo lo constituye el monasterio cisterciense de San Andrés de Arroyo (Palencia), donde se recuperó la fosa de fundición con la cámara de combustión y una tobera, y por encima el macho y las capas para moldear la campana, todo ello fechado en el siglo XIII. Esta fosa se localiza en el exterior norte de la iglesia, en la zona de los pies cerca del campanario, donde solo se fundirá una campana y será un espacio amortizado por el cementerio septentrional, San Gregorio, D. et alii, 2009: 38-40.

158 En San Francisco de Avilés se ha documentado una fosa de fundición fechada en la segunda mitad del XIII, localizándose en este caso en el subsuelo interior del templo, Ríos González, S. 2014: 218-220.

159 Por el contrario en época moderna no se documenta ninguna, lo que ha permitido sustentar la hipótesis de que a partir del siglo XVII se trajeran ya fundidas desde talleres estables asentados en las ciudades, Erasún Cortés, R. 2008: 145.

160 Como por ejemplo se ha podido documentar en el convento de San Francisco Extrapontem de Zamora, donde se excavó un foso de fundición fechado en la Edad Moderna avanzada, Miguel Hernández, F. y Marcos Villán, M. A. 1997: 453-54.

161 En el monasterio de Sant Pere de Rodes se ha documentado un foso de fundición de campanas para que el que se ha propuesto una cronología avanzada de finales de la Edad Moderna, más concretamente del siglo XVIII, Mataró, M. 2002: 76. Sobre los talleres urbanos de época moderna en la ciudad de Zamora vid. Miguel Hernández, F. y Marcos Villán, M. A. 1997: 442-43. Para la fundición de campanas en Italia en época medieval y moderna una síntesis en Redi, F. y Petrella, G. 2007. 
FIGURA 20

Vista de uno de las cuatro fosas de fundición de campanas documentados en el monasterio de Santa María de Pombeiro (Portugal) fechado entre los siglos XII y XIII, Erasún Cortés, R. 2008: 137.

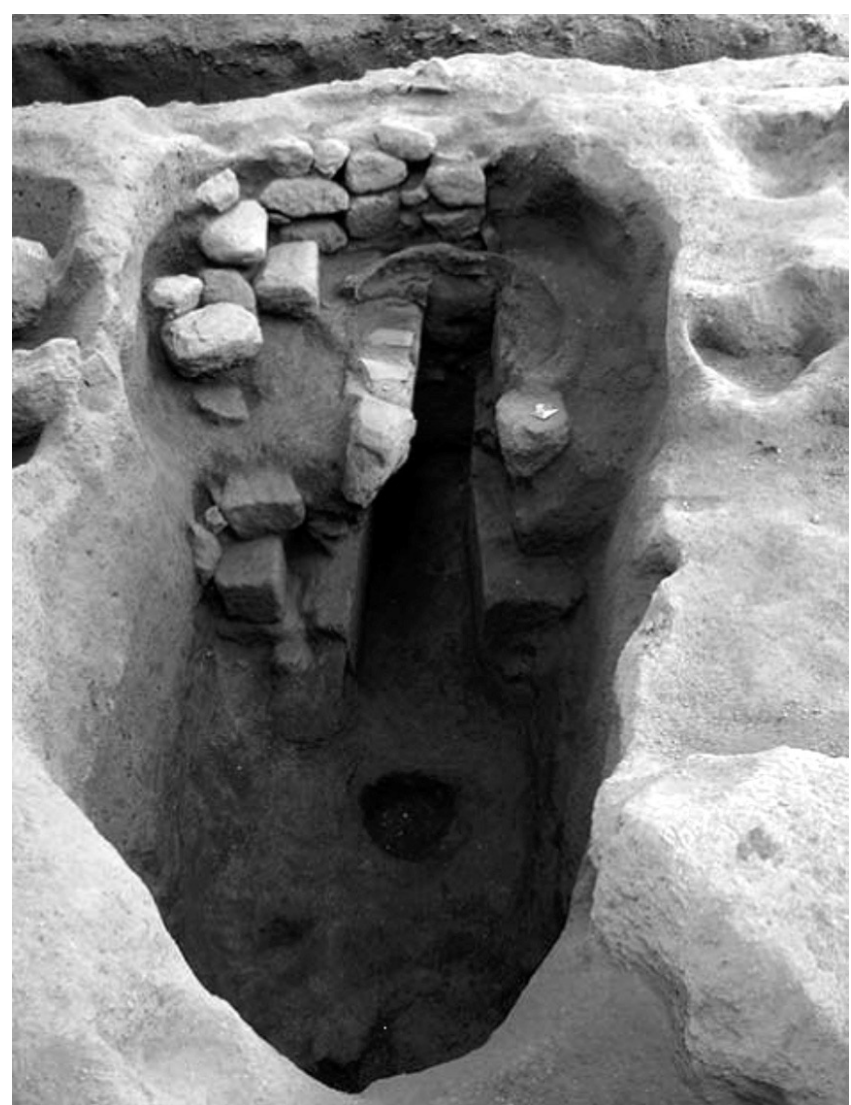

Evidentemente las carpinterías monásticas dejaron muchos menos vestigios materiales, y son las fuentes escritas las que por el momento y a duras penas nos permiten caracterizarlas. Así, en las primeras décadas del XVIII está documentado el funcionamiento de un taller de carpintería en Corias en el que se elaboraban buena parte de las piezas de madera empleadas en las reformas del edificio y su amueblamiento interno. ${ }^{162}$ Tampoco ha sido estudiada en detalle la serrería existente en las cercanías de Pombeiro, y que pudo contar en el siglo XVIII con un ingenio para serrar madera accionado con energía hidráulica. ${ }^{163}$

La última dependencia asociada a la fábrica monástica es la herrería, interesándonos aquí en su sentido de fragua donde se practicaba una metalurgia secundaria de rango menor, ya que las grandes herrerías monásticas destinadas a una producción y comercialización de mayor entidad, con beneficio del mineral de hierro incluido, se solían localizar en las granjas, aldeas y otros emplazamientos alejados del recinto monástico. Las fraguas ubicadas en el edificio conventual podían tener un carácter coyuntural, relacionadas con las necesidades de una fase constructiva determinada, pero por lo general eran de corte estructural, entendiéndolas

162 Al frente del taller se encontraba el hermano Fray Genadio y en él existía un torno de cordel, García Álvarez-Busto, A. 2011: 380-81.

163 Mendes Pinto, M. 2011: 171. como espacios de fabricación y arreglo de las herramientas empleadas en el recinto monástico. Asimismo, el dominio sobre las fraguas permitía a la comunidad monástica controlar el mantenimiento y la reparación de los medios de transformación de la producción empleados por los campesinos, como podían ser los molinos y las prensas. ${ }^{164}$ De época medieval conocemos algunos ejemplos que se ubican en edificios exentos, ${ }^{165}$ pero también en las propias pandas claustrales; ${ }^{166}$ y ya de época moderna destaca el caso de la forja del monasterio de Ferreira de Pantón, que se localizó en las inmediaciones de la capellanía. ${ }^{167}$

\section{FIGURA 21}

Forja de época moderna del monasterio cisterciense de Ferreira de Pantón (Lugo), Álvarez Merayo, I. 2008: 91.

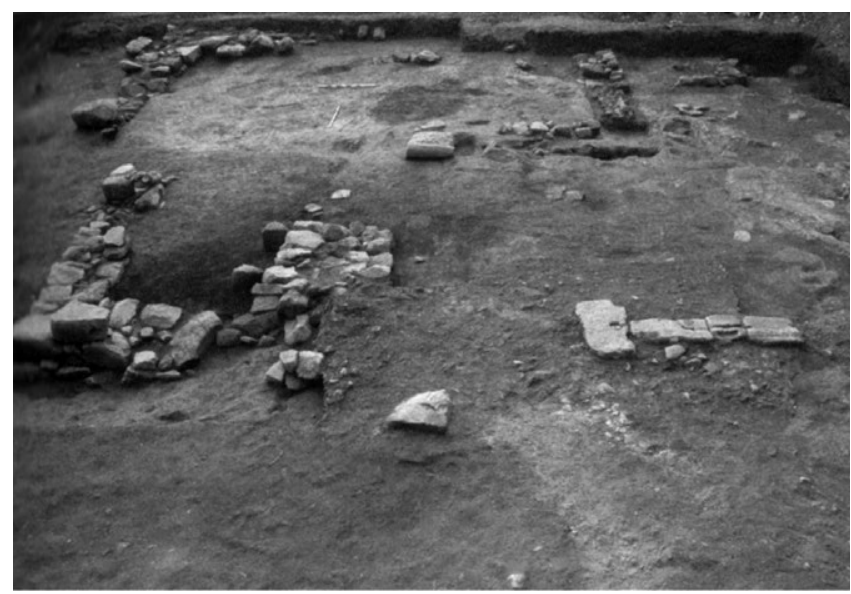

\section{Espacios artesanales asociados al servicio de la comuni-} dad claustral

En este apartado nos ocuparemos de algunas estancias relacionadas con la manufactura de ciertos productos requeridos por la liturgia y el oficio de los monjes, como eran los cirios y los pergaminos.

$Y$ es que, aunque la mayor parte de los monasterios debían de aprovisionarse de velas y cirios en los mercados externos, se sabe que algunos establecimientos contaban con cererías propias. ${ }^{168}$ Es el caso del monasterio de Corias,

164 Virgili, A. 2005: 94.

165 De época altomedieval tenemos una pequeña fragua documentada en el monasterio altomedieval de Sant Pere de Grau d'Escales, donde se localizaron escorias de bronce y hierro. Estaba situada junto a otra dependencia donde se documentó un horno de pan, Padilla Lapuente, I. 1980: 205.

166 Otra fragua medieval, aunque de cronología posterior a Grau d'Escales, se documentó en una de las estancias de la panda occidental del monasterio asturiano de Cornellana, Adán Álvarez, G. 2007: 337-338.

167 Documentándose una construcción rectangular abierta al sur y con muros de mampostería abierto al sur, y en el suelo un nivel de desechos de carbón vegetal, escorias y restos de colada. Monasterio de monjas bernardas localizado en Lugo, Álvarez Merayo, I. 2008: 91.

168 La cera era proporcionada por los campesinos dependientes o renteros, como está documentado en los cenobios asturianos de Corias, Obona, Los Oscos, Cornellana y San Vicente de Oviedo. En época moderna el monasterio de Corias llegó a recaudar 158 kg. de cera al año, López Álvarez, J. 1994: 34. 
donde a mediados del siglo XVIII está documentado "el quarto de la zerería"; 169 del monasterio de Poblet, que contaba con una cerería situada -junto con otras dependencias de trabajo- en la plaza mayor delante de la puerta fortificada de entrada al recinto monástico; ${ }^{170}$ o del de Piedra, que disponía de un ingenio hidráulico para la elaboración de la cera. ${ }^{171}$ Además de su uso litúrgico las velas eran utilizadas en la iluminación del edificio, para lo que también se podían emplear otras sustancias como el aceite de nuez. ${ }^{172}$

Por su parte los scriptoria monásticos también necesitaban verse surtidos de material de trabajo, y es sabido que los procesos de fabricación del pergamino durante la Edad Media estuvieron controlados por los propios monjes, como demuestran tratados como el del monje benedictino Teófilo en el siglo XII. ${ }^{173}$ No obstante se cree que a partir de esta centuria su elaboración se irá secularizando, por lo que perderán vigencia las antiguas manufacturas monásticas. ${ }^{174}$ De hecho las escasas evidencias existentes al respecto corresponden por el momento a monasterios tardoantiguos y altomedievales, ${ }^{175}$ y en cualquier caso y más allá de estos ejemplos aislados existe un gran desconocimiento arqueológico sobre el funcionamiento de estos escritorios a lo largo de la plena y baja Edad Media, e incluso de cómo pudo afectar en sus usos los procesos de mecanización constatados a partir de los siglos XV y XVI.

\section{Espacios hidráulicos y calentados al servicio de la comu- nidad claustral}

A continuación nos detendremos en aquellas infraestructuras y estancias que aseguraban las necesidades de la vida diaria de la comunidad relacionadas con el abastecimiento de agua y el mantenimiento de la higiene y la limpieza (letrinas, baños, lavanderías), así como en el análisis de las dependencias calentadas artificialmente.

Es bien sabido que uno de los grandes componentes entre las infraestructuras del edificio monástico eran los espacios y sistemas asociados al tratamiento del agua y la higiene. $Y$ es que los monasterios siempre dispusieron una gran diligencia en todo lo referido a la gestión del agua en el edificio conventual, tanto para garantizar el abastecimiento

169 En el que se "labraba" la cera en un pilón y posteriormente se blanqueaba en un tendal, García Álvarez-Busto, A. 2011: 378.

170 Braunfels, W. 1975: 234.

171 López López, J. 2012: 208.

172 Así está documentado en el monasterio de San Vicente de Oviedo en 1222 , empleándose en el alumbrado de la enfermería y el dormitorio de la comunidad, Ruiz de la Peña, J. I. 1977.

173 Sales Carbonell, J. 2013: 481.

174 Rodríguez Díaz, E. 2001.

175 Así, producción de pergamino se ha documentado en el posible monasterio tardoantiguo de El Bovalar, a partir del hallazgo de los peladores empleados en el trabajo de la piel, Sales Carbonell, J. 2013: 493 y ss; mientras que en el monasterio altomedieval de Portmahomack (Escocia) se documentó un área de trabajo relacionado con la fabricación de cuero y pergamino del tipo vitela, con una cronología entre los siglos VI y IX, Carver, M. 2004: 18-19. También resulta elocuente en este sentido que entre las propiedades de Corias de siglo XI se documente una "hereditas de seruicio de pargaminadores", Floriano Cumbreño, A. 1950: t. I, 68. de líquido potable y para el riego como en la evacuación de las aguas pluviales y residuales. ${ }^{176}$ No en vano desde la Edad Media los monjes destacaron por sus amplios conocimientos tecnológicos, y los tratados sobre hidráulica no faltaban en las bibliotecas monásticas. ${ }^{177}$ Entre todas las órdenes destaca el Císter en su capacidad de manejo y aprovechamiento del agua, ${ }^{178}$ no solo en el propio interior del edificio monástico sino en el desarrollo de infraestructuras en las granjas y las aldeas monásticas, así como en la mejora de los espacios de cultivo mediante la realización de complejos sistemas de drenaje y regadío. ${ }^{179}$

Por norma general los grandes monasterios de época medieval y moderna desarrollaron una ingeniería que les aseguraba el abastecimiento de agua durante todo el año. ${ }^{180}$ Estas complejas redes hidráulicas se organizaban en cinco tramos fundamentales:

1) Captación: implicaba la construcción de un aljibe por encima de la cota del monasterio y que captase las aguas de un manantial. ${ }^{181}$ En otros casos, menos, el agua se tomaba del río mediante un azud y una noria. ${ }^{182}$

2) Conducción: desde el aljibe arranca una conducción subterránea que llega hasta el edificio monástico, donde en algunos casos la conexión se resolvía mediante la disposición de acueductos y sifones. ${ }^{183}$

176 J. P. Greene (2001: 5) destaca los problemas de abastecimiento de agua y las inundaciones como algunas de las principales causas que condicionaron el éxito o el fracaso de las fundaciones monásticas en la Inglaterra medieval.

177 Pita, P. 2011: 1115

178 Vid. al respecto De la Casa, C. et alii 1998, y Pérez-Embid Wamba, F. J. 2011.

179 La obra de referencia sobre el estudio de la hidráulica monástica de época medieval y moderna es Mascarenhas, J. M., Abecasis, M. y Ferreira, V. 1996. Vid. también al respecto las referencias aportadas por F. Miguel (1989: 900) en su trabajo de síntesis; y más recientemente la tesis doctoral de J. López López (2012) sobre los sistemas hidráulicos en los monasterios cistercienses de la Corona de Aragón. Para Claraval contamos con una preciosa descripción del siglo XIII que nos informa del recorrido y aprovechamiento del sistema hidráulico: "saliendo de allí -el batán-, penetra en la tenería, donde, para preparar el material necesario para los zapatos de los hermanos (...) Luego se divide en una multitud de pequeños brazos, visita durante su complaciente curso los más diversos trabajos y por doquier busca con diligencia a aquellos que precisen sus servicios, cualquiera que sea el objeto, tanto si se trata de cocinar, cribar, moler, regar, lavar. Por último (...) se lleva las inmundicias y a su paso lo deja todo limpio. Después de que (el brazo desviado) ha realizado todo aquello por lo cual había venido vuelve con rapidez al río", Braunfels, W. 1975: 326.

180 Uno de los sistemas más complejos que conocemos es el que funcionó en época moderna en el monasterio de Pedralbes, Sanjust, C. 2010: 121 y ss.

181 En el monasterio leonés de Santa María de Carracedo se construyó a principios del siglo XVIII un edificio de planta rectangular $(8 \times 6$ $\mathrm{m}$ ) para proteger la captación de agua de un manantial -en este caso situado en la terraza fluvial-que abastecía al edificio, Miguel Hernández, F. 1989: 907. Por su parte en Corias en 1774 se construyó un aljibe rectangular con bóveda piedra captando una surgencia en la ladera, García Álvarez-Busto, A. 2011: 560.

182 Como ocurre en el monasterio aragonés de Rueda, empleando un acueducto de sillería para su conducción hasta el edificio monástico, Aguerri, F. et alii, 1996: 191-92; De la Casa, C. et alii, 1998: 44.

183 En el monasterio de Carracedo el claustro, a caballo de los siglos XVII y XVIII, presenta un ingenioso sistema hidráulico con acueductos y tubería, Balboa de Paz, J. A. 1997. Vid. también al respecto Miguel 
3) Distribución: una vez en el edificio el agua era distribuida a través conducciones forzadas soterradas o canalizaciones en régimen abierto que discurrían sobre o por el interior de los muros, alcanzado las diferentes dependencias monásticas (cocina, refectorio, lavatorios y lavamanos, enfermería, surtidor del claustro, etc.). ${ }^{184}$ En las conducciones se podían emplear canales de piedra, de madera, ${ }^{185}$ metálicos generalmente de plomo- o tubos cerámicos, junto con trampillas de registro. ${ }^{186}$

4) Almacenamiento: para abastecer las instalaciones monásticas -cocinas, baños, letrinas, lavaderos, ingenios hidráulicos- los monasterios contaban también con aljibes, cisternas y depósitos de agua alimentados por las conducciones. ${ }^{187}$

5) Evacuación: Finalmente habría que sumar un tramo final de evacuación de las aguas residuales a través de alcantarillados, y de los que nos ocuparemos más adelante.

\section{FIGURA 22}

A la izquierda: cimentaciones de las conducciones de agua del pabellón de la fuente del claustro del monasterio de Carracedo, León. Época medieval y moderna, Miguel Hernández, F. 2012.

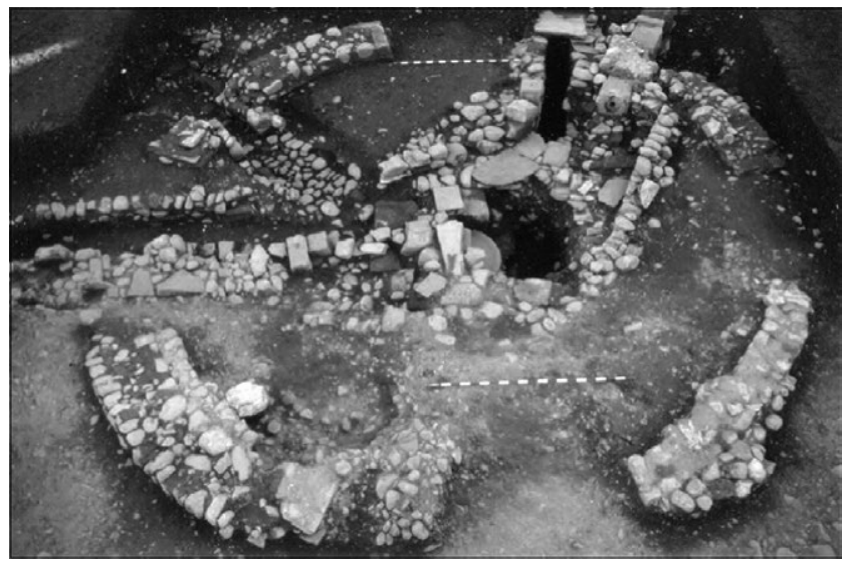

Figura 23

A la derecha: aljibe situado en el interior del patio del claustro de San Gil el Real de Madrid, Martínez Peñarroya, J. 1998: 131.

en los monasterios construidos en época moderna en América Central y del Sur se desarrollaron complejos sistemas de captación y distribución de agua potable. Por ejemplo, a mediados del siglo XVIII en el convento de San Francisco de Toluca (México) se construye un acueducto para abastecer de agua al edificio desde un manantial, Suárez Cortez, B. E. 1998: 111. En el Corias neoclásico la conducción desde el aljibe hasta el monasterio se realizaba a través de una cañería de piedra labrada, V.V.A.A. 1961: 73. Esta conducción que desciende ladera abajo penetra en el monasterio a través de un acueducto situado a la altura de la cilla y las cocinas. Desconocemos el sistema de sifón empleado en el entronque entre la tubería y el acueducto. Éste presenta fábrica de mampostería de pizarra y una canalización tapada en su parte superior. El acueducto presenta una longitud de 10,65 m, una anchura de $1,7 \mathrm{~m}$, y su arco una luz de $7 \mathrm{~m}$.

184 En el Corias neoclásico una vez que la conducción de agua llegaba al monasterio a través del acueducto, existía una red de canalizaciones por el interior de los muros maestros que abastecía de agua corriente diferentes partes del edificio, llegando incluso hasta las habitaciones situadas en la fachada principal del monasterio, hasta la bodega, y hasta la sala situada sobre el pozo negro. En la antesacristía se localiza un lavamanos empotrado en la pared oriental. Y junto a la puerta de entrada al refectorio se localizan dos surtidores en una pequeña pileta encastrada en una hornacina abierta en la pared, que servía para el lavado de las manos antes de entrar en el refectorio. En el centro del patio del claustro principal encontramos la fuente de mayor monumentalidad, alimentada por un encañado subterráneo. También tenemos constancia de la existencia de otro lavamanos en el noviciado, que se situaba en el piso principal y presentaba la fecha de 1792, García Álvarez-Busto, A. 2011: 562-63. Desconocemos cómo es la morfología de estos canales que recorren el interior de los muros. En otros monasterios la conducción forzada de agua era subterránea, mediante canalizaciones de piedra, Miguel Hernández, F. 1989: 910.

185 En el monasterio benedictino de Pombeiro se constata la existencia en el siglo XVII de un acueducto de madera que será sustituído a principios del XVIII por otro de piedra, Mendes Pinto, M. 2011: 169.

186 Resulta especialmente elocuente en este sentido la información proporcionada por Jeronimo Münzer para el monasterio de Guadalupe, Yarza, J. 1982: 385.

187 En el convento franciscano de San Gil El Real (ss. XVII- XVIII) se documentan en el centro del patio del claustro dos aljibes de planta rectangular adosados entre sí. Uno pavimentado con losas de piedra y otro con baldosas cerámicas, Martínez Peñarroya, J. 1998. También en el monasterio de Pedralbes está documentada la construcción a finales de siglo XV de una cisterna en una esquina del patio del claustro, Sanjust, C. 2010: 116 .

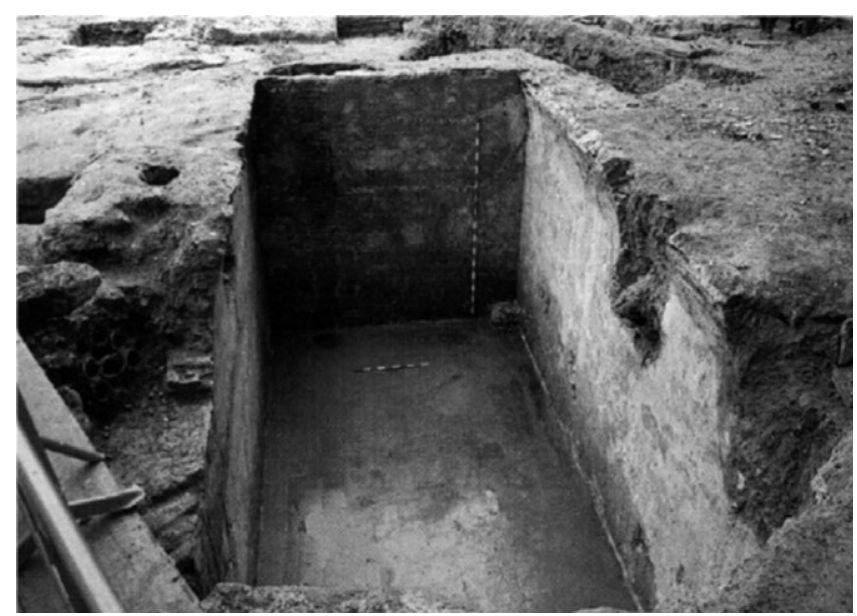

Un magnífico ejemplo de un sistema hidráulico de los siglos XIV y XV lo encontramos en el monasterio de Puebla de Guadalupe (Cáceres), donde la captación se realiza a 4 $\mathrm{km}$ del monasterio, con galerías de $200 \mathrm{~m}$ excavadas en la montaña y que alimentan un gran arca donde al agua se limpiaba de impurezas; y una vez ya en el edificio monástico el agua era distribuida al hospital, el mesón, la enfermería, las fuentes, la almazara, la carnicería y la pellejería, y el sobrante llegaba a la población anexa y a las huertas. ${ }^{188}$ También hay que destacar, por su sofisticación tecnológica, la existencia de sistemas para calentar el agua, haciéndolo pasar por una pila que era calentada en la cocina con fogones, y que en el caso del monasterio tarragonés de Pedralbes permitía a los monjes lavarse las manos con agua caliente antes de entrar

188 La conducción contaba con arquetas de registro dispuestas cada cierta distancia y atraviesa un cerro interpuesto mediante un túnel de 150 m de longitud, Vallés, J. A. 1998: 499-501. 
al refectorio; ${ }^{189}$ o la disposición en Moreruela de un torno vertical cilíndrico que hacía subir el agua desde un pozo hasta el refectorio situado en el piso alto en época moderna. ${ }^{190}$ Por su parte en edificios tan complejos como el Corias neoclásico sus constructores diseñaron una amplia serie de infraestructuras entre las que encontramos encañados soterrados de cientos de metros de longitud, acueductos ocultos que recorren el interior de las paredes, o una densa red de alcantarillas subterráneas, algunas de ellas practicables de pie. ${ }^{191}$

\section{FIGURA 24}

Plano dibujado en 1832 por Fray Hilarión Ugaldea en el que se reflejan las conducciones de agua y las alcantarillas que recorrían el subsuelo del monasterio de Corias.

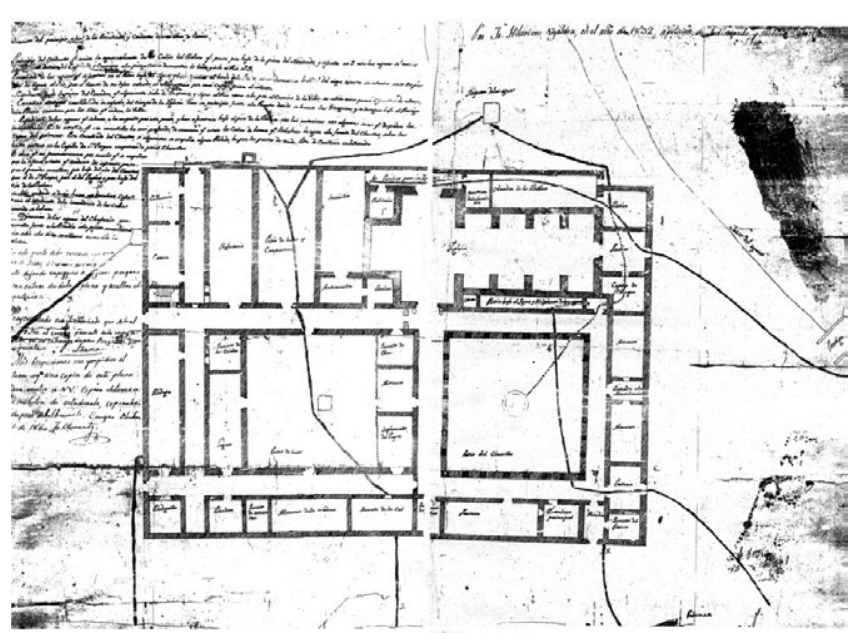

A lo largo de los edificios monásticos era frecuente encontrar fuentes artificiales de fábrica y diferentes puntos de abastecimiento de agua -lavatorio, lavamanos, etc.- Sabemos que estas fuentes se abastecían en época moderna a través de conducciones de tubos cerámicos enroscados y que en sus periódicos trabajos de mantenimiento se empleaba estopa, bramante y aceite. ${ }^{192}$ En ocasiones las tuberías iban protegidas por unos muretes laterales de acompañamiento, pero otras veces iban encastradas en canalizaciones labradas en piedra. ${ }^{193}$

189 Documentados en Pedralbes y Guadalupe en los siglos XV y XVI, Sanjust, C. 2010: 122. Para Guadalupe contamos a finales del siglo XV con la descripción de Jerónimo Münzer quien vio "en las cocinas los depósitos para el agua fría y caliente abastecidos por cañerías...", Miguel Hernández, F. 1989: 901.

190 Salvador, M. y Viñé, A. I. 2008: 417-18.

191 Además para este caso concreto contamos con una fuente gráfica de primer orden, como es el plano dibujado en 1832 por Fray Hilarión Ugaldea, y en el que traza el recorrido de las principales atarjeas y acometidas de agua que recorrían el subsuelo del edificio neoclásico.

192 En Corias se han documentado varias tuberías vinculadas a la fase neoclásica. Cada tubo mide $38 \mathrm{~cm}$ de longitud y 10,5/15 cm de diámetro, presentando roscas (macho y hembra) en sus extremos, García Álvarez-Busto, A. 2011: 389-390. En algunos monasterios, como en Pombeiro, está atestiguada en el siglo XVIII la sustitución de las antiguas canalizaciones por tuberías de plomo, Mendes Pinto, M. 2011: 165.

193 También en Corias se han podido documentar algunos tramos de estas canalizaciones pétreas, que presentan $95 \mathrm{~cm}$ de largo, y una canaleta

\section{FIGURA 25}

Canalización de agua del monasterio de Corias con tubería cerámica protegida por muretes laterales.

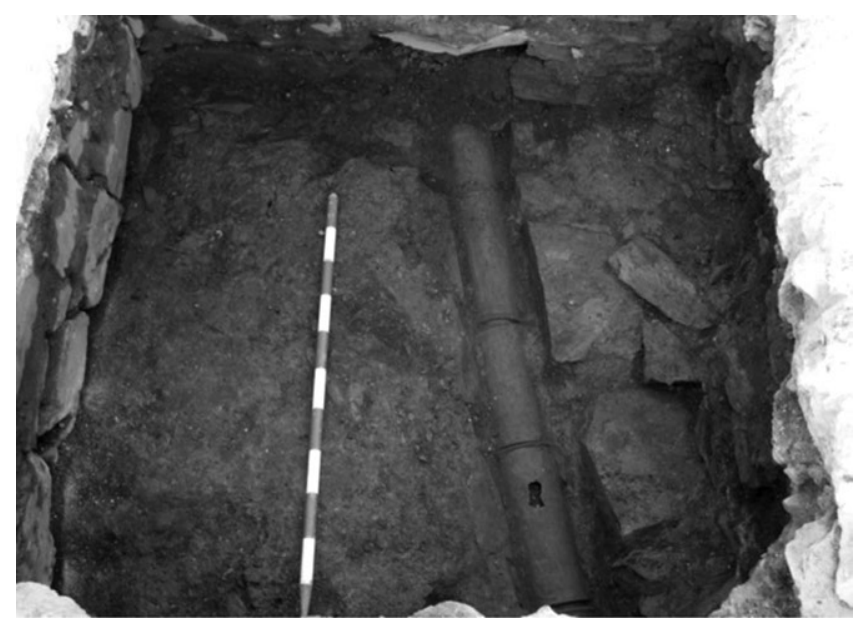

La construcción de encañados de tubos cerámicos resulta habitual en los monasterios de época moderna, que tendrán en la mejora de las infraestructuras de abastecimiento hídrico una de sus preocupaciones durante los siglos XVI y XVII, ${ }^{194}$ a la par que algunos conventos urbanos dispusieron gran celo tanto en el abastecimiento de agua potable como en la evacuación de las aguas residuales al calor de las políticas sanitarias impulsadas por los regimientos municipales. ${ }^{195}$

Pero no siempre los monasterios contaron con complejos sistemas de abastecimiento hídrico, y en ocasiones tenían que servirse de métodos más rudimentarios. Muchas veces en la inmediatez del edificio existían fuentes naturales y manantiales que abastecían de agua potable a la comunidad, y que eran mínimamente acondicionadas para su uso. ${ }^{196}$ En otras ocasiones era necesario excavar la roca y construir pozos de agua. Muchos de ellos se localizan en el jardín del claustro, en su centro, ${ }^{197}$ o en una esquina cerca de

interior de media caña de $15 \mathrm{~cm}$ de ancho. Los extremos del tramo presentan los laterales embocados para poder ser encajados con otros tramos.

194 Por ejemplo, en el siglo XVI, en la escritura de concordia entre el concejo de Avilés y el convento de Las Huelgas se disponía que se diese a las monjas "un caño de agua de la que corre por la Villa para meter en el monasterio y además, la fuente primera que está a los hórreos, a las espaldas de la huerta que se compró", Garralda, A. 1970: 300. Y también es conocido que en la primera mitad del siglo XVII la mayor parte de los cenobios ovetenses renovaron sus traídas de agua. En 1657 se conoce el contrato de la construcción de un encañado en el monasterio de Santa María de la Vega en Oviedo. Los caños estaban asentados sobre losas, y se emplea betún para la impermeabilización, elaborado con cal, escoria, teja molida y aceite. También se construye una fuente con pila y un lavadero anexo dentro de la cerca del monasterio, Kawamura, Y. 2006. Una revisión de las investigaciones sobre los sistemas hidráulicos en los monasterios peninsulares y europeos puede verse en Miguel Hernández, F. 1989.

195 Un caso especialmente interesante se constata en las obras de renovación de las conducciones -incorporando caños cerámicos vidriados- y de los alcantarillados acometidas por el convento barcelonés de carmelitas descalzas tras la gran mortandad provocada en 1589 por la peste, Busquets, C. y Pastor, I. 2002: 152.

196 Es el caso de la "fuente de la paciencia", situada en el patio trasero del monasterio de Corias.

197 Como ocurre en el monasterio benedictino de Santa María di Montescudaio. Fase de los siglos XII-XIV, Baldassarri, M. et alii, 2012: 472-73. 
la cocina; ${ }^{198}$ también en las galerías claustrales; ${ }^{199} \mathrm{y}$, como ya hemos visto, en las cocinas o en las huertas de las celdas. ${ }^{200}$ Se conoce además el aprovechamiento del agua de lluvia de los tejados, como ocurre en época moderna en el monasterio de Pedralbes, donde se recogía el agua en el patio del claustro mediante bajantes y conducciones que llevaban el líquido a un primer pozo en el que se decantaban las impurezas rebosando en una gran cisterna. ${ }^{201}$

Por otra parte los sistemas de alcantarillado de los monasterios cumplían una doble función: por un lado evacuar las aguas sucias generadas por la comunidad claustral (letrinas, lavaderos, etc.), y por otro asegurar el mantenimiento arquitectónico del edificio, dando salida no solo a las aguas pluviales que soportaba el edificio sino también a las aguas de escorrentía de ladera, dado que en muchas ocasiones los monasterios se emplazaban en fondos de valle afectados por las torrenteras. ${ }^{202}$

Habitualmente toda la planta del edificio monástico albergaba una laberíntica red de drenajes y colectores, ${ }^{203}$ y en algunos casos las aguas residuales, después de recorrer todo el monasterio -cocinas, letrinas, lavaderos, etc.- eran aprovechadas para el regadío de los huertos. ${ }^{204}$ En la gestión de estas aguas sucias y de las excreciones humanas se empleaban bacines y orinales de cerámica, siendo habitual su uso en el dormitorio y en las celdas, aunque los monasterios de cierto porte disponían de letrinas bien acondicionadas que normalmente se localizaban en la panda oriental del claustro, a continuación del dormitorio de los monjes, y que estaban provistas de asientos y estrechas

198 Caso del monasterio cisterciense de Fitero en el siglo XVI, Olcoz, S. 2008: 172 .

199 Como en San Vicente de Oviedo o Santa María de Villamayor de los Montes en Burgos, Abad Castro, C. 1998b: 243.

200 Es el caso de la Cartuja de Sevilla, Amores, F. et alii, 1989: 934.

201 Este depósito presentaba unas dimensiones en planta de 7 × 7 $\mathrm{m}$, más 8 de profundidad, que le proporcionan una capacidad de $252 \mathrm{~m}^{3}$. Para purificar el agua se le hacía pasar por una piedra pómez de $80 \mathrm{~cm}$ de grosor, Sanjust, C. 2010: 118.

202 Un caso paradigmático en este sentido es el del monasterio de Aude, donde los monjes aprovecharon una fisura abierta en la roca en el patio norte para evacuar el agua de torrentera, De la Casa, C. et alii, 1998: 44. Acerca de esta cuestión son conocidas varias referencias a los trabajos de mantenimiento efectuados en el siglo XVIII en Corias, y que consistían en la limpieza periódica de la zanja-alcantarilla que protegía la iglesia renacentista, llegando incluso a construirse una antepoza para que el agua no entrase en el interior del templo. Durante el seguimiento arqueológico realizado en este monasterio se pudo identificar esta alcantarilla que presenta tramos adintelados y otros abovedados. Está excavada en el substrato rocoso, presentando una anchura media de 60-70 cm, aunque en algunos tramos llega a alcanzar los 100-120 cm, García Álvarez-Busto, A. 2011: 393-94. También en Santa María de Huerta (Soria) se construye a principios del siglo XIX una atarjea abovedada con el mismo fin de proteger a la iglesia del agua, Miguel Hernández, F. 1989: 903.

203 En Corias la obra del nuevo monasterio neoclásico supuso la construcción de una compleja red de alcantarillas que en buena parte se centralizaban en un pozo negro subterráneo situado bajo las letrinas de los pisos superiores. Desde este pozo central, así como desde la cocina y desde la cámara abacial -situada en la esquina noroeste de la fachada principal del edificio-, arrancaban tres colectores principales que desaguaban en el cercano curso del río Narcea.

204 Como está atestiguado en el monasterio de Pedralbes, Sanjust, C. 2010: 124 . ventanas que las iluminaban y ventilaban. ${ }^{205}$ Monasterios de la entidad de Cluny contaban con hasta cinco conjuntos de letrinas diferenciados ya en el siglo XI. ${ }^{206}$ Las letrinas podían ser comunes (monjes, novicios, enfermería) o privadas (cámara abacial), y en la documentación escrita suelen aparecer nombradas con eufemismos tan variados como las secretas, privadas, necesarias o los excusados y lugares comunes. ${ }^{207}$

Básicamente se pueden distinguir dos tipologías de letrinas: las dispuestas sobre pozos negros, ${ }^{208}$ y las que se saneaban mediante el empleo de canales de agua. Cuando era posible se construían siguiendo este último tipo, sobre corrientes que a veces tenían que ser desviadas y encauzadas para facilitar la evacuación de los residuos, que en ocasiones también eran aprovechados para el regadío de los huertos. ${ }^{209}$ En Europa están bien documentadas en época medieval, ${ }^{210}$ mientras que en la Península Ibérica los ejemplos mejor conservados son tardomedievales o ya de época moderna. ${ }^{211}$ En ocasiones las aguas no eran evacuadas y las letrinas vertían a pozos negros ciegos y secos, de hasta 10 metros de profundidad, ${ }^{212}$ y que si se encontraban a ras

205 Tal y como se aprecia en la mayor parte de los monasterios cluniacenses y cistercienses. Un buen ejemplo bien conservado lo encontramos en la abadía cisterciense de Royaumont, donde las letrinas se disponen a lo largo de un pasillo de más $30 \mathrm{~m}$ de longitud. En ocasiones también se localizaban entre el dormitorio y la iglesia. Vid. al respecto, Yarza Luaces, J. 1982: 73; Aubert, M. 1943; Sanjust, C. 2010: 133.

206 De la Casa, C. et alii, 1998: 44.

207 En el monasterio de Corias -en el edificio renacentista-barroco a principios del siglo XVIII- existían además de las letrinas comunes de los monjes otras en el noviciado y en la cámara abacial, García ÁlvarezBusto, A. 2011: 383. En el monasterio de Oia entre 1738 y 1741 también se reforman las letrinas situadas junto a las celdas, Manso Porto, C. 2002: 292.

208 Dentro de los cuales también existe una amplia variedad, ya que los hay ciegos -en muchas ocasiones secos y en los que se vierte tierray otros en los que confluyen y de los que parten alcantarillas.

209 Así se documenta en el monasterio de Pedralbes, Sanjust, C. 2010: 135 .

210 En el monasterio de Clairefontaine (Luxemburgo) desde la fase fundacional del siglo XIII se disponen las letrinas sobre una corriente de agua en una esquina del claustro a continuación del refectorio. Las letrinas sufrirán reformas continuadas en época medieval y moderna, Herremans, D. y Coomans, Th. 2013: 121; mientras que en el priorato inglés de Mount Grace ha sido posible reconstruir la morfología de las secretas del siglo XV. Se fechan hacia 1400 sufriendo una reforma en torno a 1420. Cada letrina presenta un asiento de madera con un agujero circular sobre una corriente de agua, Coppack, G. 1996: 61.

211 Un buen ejemplo de esta tipología de letrinas - con fábrica de sillería- son las del convento dominico de Batalha (siglos XV-XVI), Ferreira Jorge, V. 1996: 124; y las posteriores -siglo XVIII- pero muy similares de la abadía cisterciense de Sao Cristóvao de Lafoes, Correia, C. y Ferreira, V. 1996: 230-31. Otro modelo más avanzado lo conocemos en Pedralbes en época moderna, donde se hacía llegar el agua hasta las letrinas mediante conducciones forzadas, Sanjust, C. 2010: 123.

212 Como sucede en las letrinas de los legos del monasterio de Santa María de Cuevas o en las del convento colonial de Santa Catalina (Buenos Aires). Mediados del siglo XVIII. Pozo de 4,45 por 1,8 m y $10 \mathrm{~m}$ de profundidad, cubierto por una bóveda, sobre la que se ubican los asientos con agujeros, Schávelzon, D. y Silveira, M. 2005. En este edificio las privadas estaban diferenciadas, existiendo una particular para las monjas que se ubicaba cerca de la huerta. En el interior de su pozo ciego se recuperaron cerámicas y bacines, huesos de comida (se pudo documentar la dieta con los restos de mamíferos, peces y aves), escombros y capas de tierra echadas para evitar los malos olores, todo ello depositado en pequeños estratos superpuestos que demostraban una lenta 
de suelo contaban con un pozo de poco calado al que se accedía a través de una escalera, permitiendo su periódico vaciado a mano por un criado. ${ }^{213}$

\section{FIGURA 26}

Letrinas del convento dominico de Batalha (siglos XV-XVI), Ferreira Jorge, V. 1996: 124

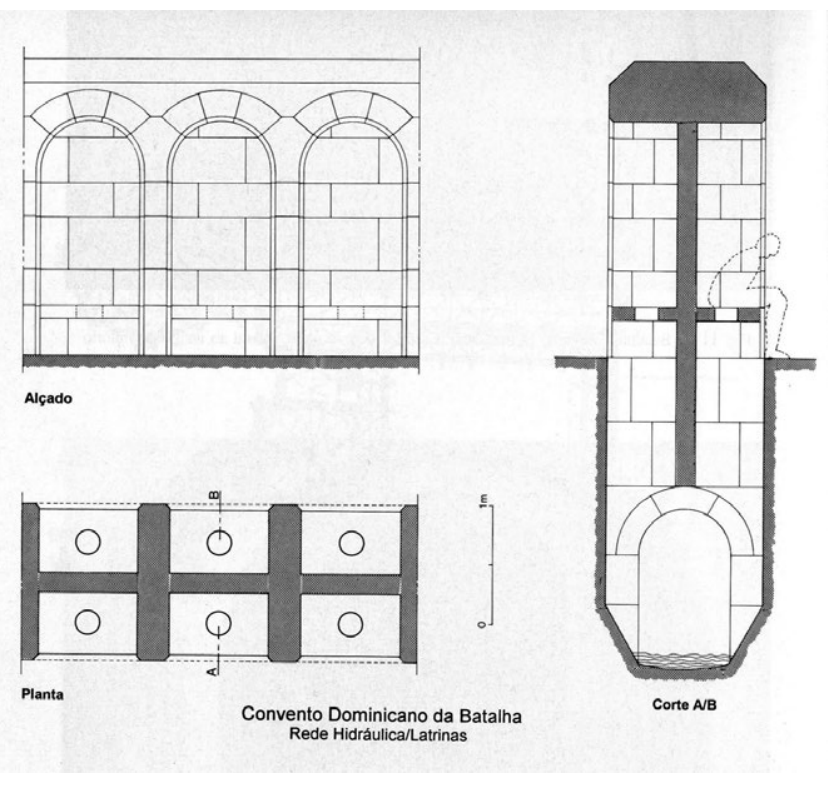

Otra variable a tener en cuenta con respecto al mantenimiento de la higiene en los monasterios es la cuestión del aseo personal. El Capítulo XXXVI de la regla benedictina específica que los monjes tenían restringido el baño unas pocas veces al año -especialmente los más jóvenes,$-{ }^{214}$ a no ser que estuvieran enfermos, para los que se recomendaba siempre que éste fuera conveniente. ${ }^{215}$ Por su parte en el programa arquitectónico de los primeros monasterios cistercienses tampoco aparece contemplado un espacio individualizado dedicado al aseo de los monjes. ${ }^{216} Y$ pese a estas reticencias iniciales algunos de los mejores y más completos baños del Medievo se localizaron en los monasterios, ${ }^{217}$ y en la excavación de algunos conventos de época moderna se han localizado instrumentos de higiene personal que reflejan un estatus señorial de los religiosos. ${ }^{218}$

y continuada sedimentación. El pozo se ciega y amortiza con relleno de escombro cuando se construye en sus inmediaciones en 1808 una nueva enfermería.

213 Así está documentado en el convento jesuita argentino de Tucumán, donde el pozo tenía un metro y medio de profundidad, Ibídem.

214 El Capítulo cisterciense de 1437 establecía que a los monjes sanos no se les permitía tomar más de un baño al mes, Bango Torviso, I. 1998: 85 .

215 De hecho las enfermerías de monasterios altomedievales de referencia como San Gall o Cluny II contaban con baños propios, Martínez de Aguirre, J. 1992: 85

216 Leroux-Dhuys, J. F. 1999: 65.

217 Vid. al respecto los trabajos de Smith (2007), Squatriti (2008) y Archibald (2012)

218 Es el caso del monasterio de Santa Clara-a-Velha de Coimbra (siglos XVI-XVII), en cuyas excavaciones arqueológicas se documentó un refinado repertorio de instrumentos de higiene personal
En el detalladísimo plano de Sant Gall aparecen hasta seis baños (para el abad, la enfermería, el noviciado, los monjes, etc.), algunos de ellos utilizados con fines terapéuticos. Llama la atención que los aseos principales de los monjes se localizaban junto al calefactorio principal y las letrinas, proximidad que seguramente se explica por el uso compartido de instalaciones hidráulicas y calefactoras en estas estancias, en una clara economía de medios tras la que subyacía un metódico diseño. Otro referente en este sentido es el edificio de Cluny II, en el que los monjes contaban en el siglo XI con un lavatorium secretum para el baño íntimo, además de vestuario y varias letrinas. ${ }^{219}$ También se sabe que en el monasterio inglés de Abingdon al abad Vincent (1121-1130) había construido unos baños para los monjes. ${ }^{220}$ Finalmente, otro espacio vinculado a la higiene y la liturgia de la comunidad era la barbería, relacionada con el cumplimiento del afeitado y la tonsura por parte de los monjes. ${ }^{221}$

Por otro lado los monasterios más importantes contaban con una lavandería destinada a hacer la colada de la ropa, siendo el Escorial el edificio de referencia en España en este sentido, y que ya en 1582 disponía una provisión para construir el batán y el lavadero de ropa. ${ }^{222}$ Por su parte en el monasterio de Pedralbes en el siglo XVı los lavaderos de la ropa compartían abastecimiento de agua corriente con las cocinas, ${ }^{223}$ y de hecho se situaban en el "claustrum retro coquine" configurando una suerte de impluvium con galerías cubiertas en las que se tendía la ropa. Antes de tener agua corriente ésta se tomaba de un pozo, y en la pared pegada a la cocina se localizaban varias pilas donde se hacía la colada empleando ceniza y agua caliente. ${ }^{224}$ En el caso de Santes Creus la lavandería también estaba conectada al sistema general de abastecimiento hidráulico que recorría el edificio. ${ }^{225}$

Dependiendo del tipo de orden la colada la hacían los propios religiosos, ${ }^{226}$ o se servían de criados. Particularmente contamos con buenos datos sobre este asunto en el monasterio de Corias, ya que sabemos que a mediados del siglo XVIII había cinco mujeres encargadas de lavar la ropa de la comunidad; ${ }^{227}$ y un poco más tarde la cillería del edificio

(peines, lavaojos, lavaoídos, limpiauñas o mondadientes), Cunha Leal, C. y Almeida Ferreira, M. 2006: 98-99.

219 Conant, K. 1968.

220 Bond, C. J. 1989: 89

221 En el siglo XIII los capítulos cistercienses establecían la obligatoriedad de la tonsura al menos una vez al mes, Bango Torviso, I. 1998: 85. Aparece consignada una en 1572 en el monasterio de Villanueva de Oscos, Álvarez Castrillón, J. A. 2009. Por su parte la peluquería del convento femenino de San Lorenzo (México) contaba con "un horno exiguo, una vasija de cobre sobrepuesta al horno, para confeccionar lejía, y un receptáculo de agua sucia”, Tovar Esquivel, E. 2000: 70.

222 Andrés, G. 1976: 101.

223 Sanjust, C. 2010: 116.

224 Ibidem: 155-56.

225 López López, J. 2012: 281.

226 Como ocurre en las Descalzas de Santa Clara de Madrid: "Hazen colada en comunidad, tañendo la campanilla de obediencia, y lleva cada una su ropa para limpiar. Señálense dos para que hagan la colada por el mismo orden que las cocineras, teniendo cuenta especial con la ropa de uso de cada una", Carrillo, J. 1616: 32.

227 Diferenciada por de la cámara, de la hospedería, del refectorio y la lencería de la sacristía, García Álvarez-Busto, A. 2011: 375. 
neoclásico contó con un lavadero cuyos vestigios fueron documentados arqueológicamente, tratándose concretamente de una piedra de "bogadeiru", 228 que formaba la base del artilugio donde se hacía la colada -empleando para ello agua caliente y ceniza-. ${ }^{229} \mathrm{Y}$ es que en los siglos XVIII y XIX se multiplicaron las lavanderías en los monasterios, ${ }^{230}$ a la par que se publicaban numerosos tratados higienistas explicando cómo hacer la colada de la ropa con lejía de cenizas vegetales -que contienen sosas y potasas- en cubas de madera. ${ }^{231}$

\section{FIGURA 27}

En una de las esquinas de la cillería de Corias se conservaba una piedra solera de un bogadeiru, el ingenio en el que se hacía la colada empleando agua caliente y ceniza.

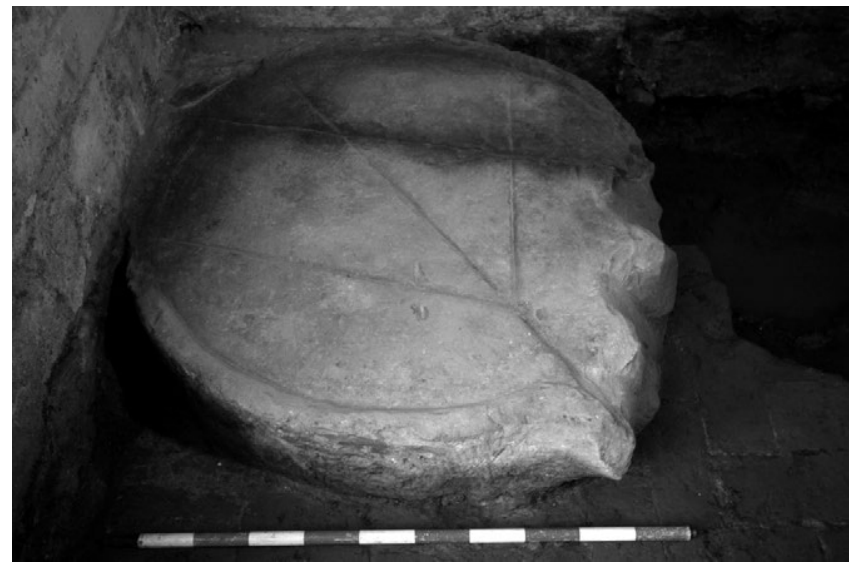

Muy vinculada a la lavandería se encontraba la sastrería del monasterio, aunque no conocemos ninguna de ellas desde una perspectiva arqueológica; ${ }^{232}$ y otros artilugios relacionados con el tratamiento de la vestimenta eran los batanes, habituales también entre las propiedades monásticas aunque solían localizarse junto a algún río fuera del recinto.

Otro gran apartado de las infraestructuras de la arquitectura monástica lo comprendían los sistemas asociados a la calefacción del edificio. Y es que para hacer frente a los rigores invernales los monasterios disponían de calefactorios, salas templadas donde la comunidad claustral pasaba buena parte de las horas durante las estaciones frías. Estos sistemas activos de calefacción se complementaban con otros de

228 La piedra tiene $105 \mathrm{~cm}$ de diámetro, siendo sensiblemente mayor que la media habitual de $60 \mathrm{~cm}$ que presentan las que se encuentran en las viviendas campesinas. Este artilugio también es denominado en Asturias entremisu.

229 Lo que explica la proximidad del bogadeiru a la cocina.

230 Por ejemplo en el monasterio cisterciense de Santa María de Villanueva de Oscos, Paz González, D. 1991: 150.

231 Real Jardín Botánico, 1797, pp. 6-7; García Verdugo, V. 1851: 3117-3120.

${ }^{232}$ Lo que sí sabemos es que a principios del siglo XVIII Corias disponía de una sastrería que contaba con una prensa para las cogullas, García Álvarez-Busto, A. 2011: 373; mientras que en el monasterio leonés de Vega era habitual que del arreglo de la ropa se encargase un alfayate que residía en la aldea situada extramuros del edificio monástico, Domínguez, S. 2013: 52. carácter pasivo, cuyos mejores ejemplos los encontramos en las solanas y las galerías porticadas orientadas al sur.

En el plano de San Gall (s. IX) aparecen dibujadas tres calderas a la manera de un praefurnium romano, las cuales alimentaban los tres calefactorios existentes en el edificio reglar: el de los monjes, el de la enfermería y el del noviciado. En este prototipo benedictino carolingio, como en muchos monasterios reales, el calefactorio principal se localizaba debajo del dormitorio, proporcionándole también calor mediante un sencillo principio físico por el cual el aire caliente tiende a ascender.

Esta disposición en vertical de las salas calentadas, que suponía un considerable ahorro de energía, lo encontraremos -con mayor o menor complejidad- en diferentes monasterios de época medieval o moderna. Uno de los modelos más avanzados lo hemos podido documentar en el edificio neoclásico de Corias, en cuya crujía interclaustral se localiza una chimenea con bocas abiertas en la planta baja, el primer y el segundo piso. En estas habitaciones con chimenea se localizaba el calefactorio, seguramente el común en el primer piso diferenciado del de la enfermería en el segundo. ${ }^{233}$

\section{FIGURA 28}

Boca tapiada de la chimenea del calefactorio situado en el primer piso del edificio neoclásico de Corias

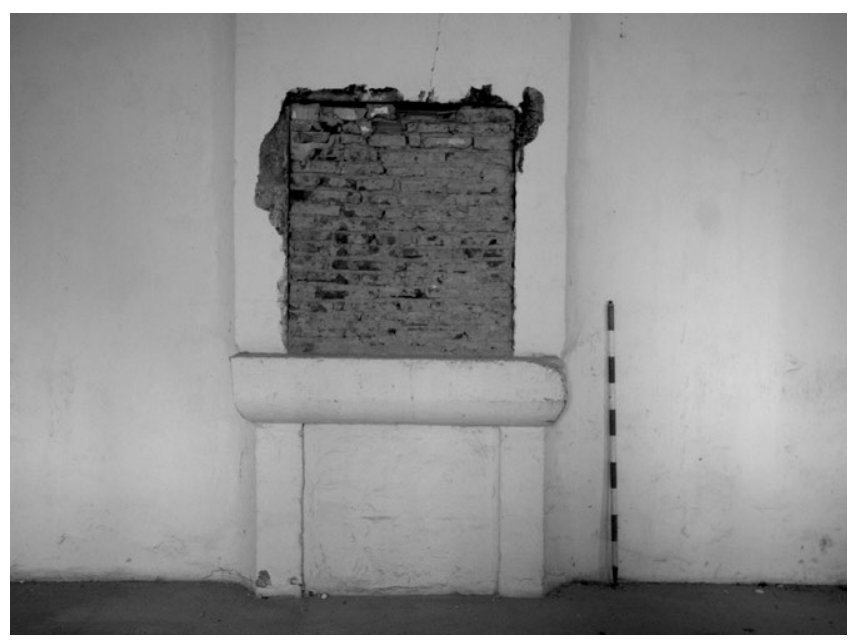

En otros casos el calefactorio se situaba en el primer piso sobre la planta de la cocina, utilizándose de esta manera el calor generado en los fogones para calentar la sala templada de los monjes. Evidentemente todos estos sistemas verticales simplificaban enormemente la necesidad de construcción de infraestructuras, ya que una misma chimenea servía a la cocina y al calefactorio. ${ }^{234}$ Por el contrario en los monasterios cistercienses era habitual que el calefactorio estuviese en la planta baja del claustro -al menos durante

233 Por su parte la cámara abacial coriense contaba con una chimenea independiente, García Álvarez-Busto, A. 2011: 536.

234 Como se ha podido identificar en la fábrica del siglo XVIII del monasterio de Santa María de Melón en Orense, Blanco Rotea, R. y Fernández Rodríguez, B. 2013: 51-54. 
la Edad Media-, cerca del refectorio y la sala de lo monjes, y calentado con una gran chimenea central o adosada a una de las paredes. ${ }^{235}$

No nos consta por el contrario la existencia en la Península Ibérica de mecanismos de calefacción más complejos, que sí fueron empleados en los países centroeuropeos, en los que el rigor climático impuso su desarrollo durante los siglos bajomedievales. Concretamente nos estamos refiriendo a los sistemas de calefacción por aire documentados en los calefactorios de los conventos franciscanos de Ulm y Breitenau en Alemania, y donde se han identificado hornos de combustión de madera y estructuras de conducción que llevaban el aire caliente hasta las estancias de invierno. ${ }^{236}$ Por supuesto estos sistemas complejos necesitaban de más personal de trabajo y de mantenimiento que los calefactorios más sencillos alimentados por tan solo un hogar. ${ }^{237}$

\section{Espacios de hábitat de los laicos al servicio de la comunidad}

Como ya hemos visto la familia monástica estaba formada, amén de los monjes clérigos y de los hermanos legos, por un amplio número de laicos que trabajaban al servicio de la comunidad; pero como tradicionalmente la atención de la historiografía monástica ha estado centrada en los religiosos es muy poco lo que sabemos sobre las condiciones de vida de estos trabajadores, y lo mismo ocurre en particular con respecto a los espacios que habitaban. Éstos normalmente se encontraban alrededor de la clausura monástica, y ya en el plano de San Gall los alojamientos de los criados y buena parte de las instalaciones de trabajo y las cuadras para el ganado se encuentran dibujados al oeste y al suroeste del monasterio.

Un buen ejemplo lo constituye el compás situado a la entrada del monasterio burgalés de Las Huelgas, en el que residían los siervos, familiares, oficiales y clérigos vinculados al monasterio, y donde se concentraba una gran actividad artesanal y comercial favorecida por la abadesa mediante la concesión inmunidades y exenciones. ${ }^{238} \mathrm{O}$ también el compás de Arroyo, en el que se localizaban las casas del capellán y del mandadero, junto con la hospedería, un aljibe, la botica, la fragua, la alberguería, las caballerizas y el patio de carruajes. $^{239}$

Al calor de estos focos económicos medievales extra claustrales resulta habitual que se consolidase una pequeña

235 Bango Torviso, I. 1998b: 103, nota 15. Por poner dos ejemplos en el monasterio de Rueda el hogar se ubica en el centro del calefactorio, mientras que en Poblet ocupa un muro lateral, Abad Castro, C. 1998b: 238-39.

${ }^{236}$ Se trata de técnicas de calefacción que tecnológicamente recuerdan a los procedimientos romanos, y que también se documentan en castillos y palacios medievales de Escandinavia, Alemania, Austria o Suiza. Vid. al respecto Bräuning, A. y Stelzle-Hüglin, S. 2002.

237 Sabemos por ejemplo que en el monasterio benedictino femenino de Torun (Polonia) había cinco hombres (rustici) encargados de mantenimiento de las estufas existentes dentro de la clausura, Linage Conde, A. 2007: 435.

238 López de Guereño, Mạ T. 1998b: 272.

239 Ibídem: 272. En el caso del monasterio de Santa Clara La Real de Murcia los sirvientes, en su mayoría varones, residían en el siglo XVIII en una casona adyacente al monasterio, Vilar, Mạ J. 2011: 500. población donde residían los laicos vinculados de una u otra manera al monasterio, y que funcionaban como centros de atracción de poblamiento. Asimismo será el lugar donde se asienten los diversos oficiales y artesanos que atendían la demanda claustral: zapateros, guarnicioneros, sastres, curtidores, orfebres, etc. Lamentablemente no conocemos ninguna investigación arqueológica que se haya ocupado en particular del estudio de estos asentamientos, del urbanismo que desarrollaron en su interior o de las infraestructuras viarias que se fueron generando en su entorno.

En estos núcleos anexos al monasterio también se localizaban algunas dependencias de servicio, como ocurre junto al monasterio San Estevo de Ribas do Sil, donde en época moderna encontramos la cárcel, la panadería y un molino harinero. ${ }^{240}$ Por su parte en Santa María de la Vega de Oviedo la documentación escrita del siglo XVI nos proporciona una buena imagen de cómo se configuraba el exterior del monasterio por entonces, ya que sabemos que se encontraba delimitado por un "cercado", 241 y a su entrada contaba con un espacio cerrado, la corrada, jalonado por las viviendas de los sirvientes. ${ }^{242}$

Aunque lo acostumbrado fuera que a los laicos se les obligase a residir fuera del recinto monástico en algunos casos también se documentan habitaciones para criados en el interior del propio edificio conventual. ${ }^{243}$ Están atestiguadas en Pedralbes en el siglo XV como la Casa de la Companya, la estancia donde viven y duermen las criadas de las monjas, y que se localizaba en una sala superior con acceso a través de una escalera; ${ }^{244}$ y en Corias como el "quarto de los mozos" a principios del siglo XVIII, contando con camas y un corredor de madera, por lo que también debía encontrarse en el piso alto. ${ }^{245}$

\section{CONCLUSIONES}

A modo de valoración final, y tras la revisión de los diferentes espacios monásticos orientados a la producción económica y al servicio de la comunidad religiosa, resulta factible plantear una serie de reflexiones que incorporen nuevos interrogantes y perspectivas a la futura investigación arqueológica de los edificios monásticos en la Península Ibérica.

De esta manera a partir del análisis realizado hemos visto que algunos monasterios desarrollaron un considerable grado de complejidad en todo lo referido a la dotación de estancias de trabajo y de servicio, así como al conjunto de infraestructuras vinculadas a estas dependencias. Desde este punto de vista la imagen del edificio monástico dista mucho de las recurrentes idealizaciones en las que se representa un monumento prístino, limpio y puro, a la manera de Viollet-le-Duc, y tendremos que acostumbrarnos a la

240 Castiñeiras, M. A. 2006: 64.

241 También aparece denominado como la "muralla" o el "muro".

242 "dos casas de murio e de madera, techadas de tella, (...) un orrio de madera techado de palla", Martínez Vega, A. 1994.

243 En Santa María de Obona, entre las dependencias del nuevo claustro que se estaba construyendo en 1658 se consigna el "aposento de moços", Sanz Fuentes, Ma J. y Buría Fernández, Mạ J. 2002: 86.

244 Sanjust, C. 2010: 154.

245 García Álvarez-Busto, A. 2011: 374. 
visualización del monasterio como un complejo -santuario y factoría a partes iguales- en el que alrededor del ámbito religioso propio de los monjes -véase iglesia y claustro- se dispone un ámbito laboral y productivo, atendido en buena parte por lo laicos que integraban la familia monástica.

Resulta además evidente que es imprescindible ampliar y mejorar nuestro grado de conocimiento sobre la materialidad de estas dependencias e infraestructuras, dado que en una buena parte de los casos todavía mantenemos una subordinación casi absoluta al registro escrito para tratar de diseccionar estas otras "realidades monásticas". Estas carencias resultan especialmente notorias en todo aquello relacionado con los espacios domésticos habitados por los seglares que trabajaban en el monasterio; espacios de los que prácticamente lo desconocemos todo, empezando por su configuración o su localización en el interior del recinto monástico, más allá de las vagas referencias que nos permiten intuir las habitaciones de los criados como unas modestas estancias, en buena parte construidas en madera, y que se encontraban arrinconadas en los pisos altos del edificio o en los compases de entrada. Otra cuestión que lamentablemente tampoco ha sido abordada por la arqueología es el análisis de los núcleos de población que surgieron alrededor de los recintos monásticos, aunque ésta tenga una importancia capital para comprender en general los procesos de formación y desarrollo del poblamiento de época medieval y moderna, y particularmente los sucedidos en torno a numerosos monasterios que funcionaron como centros de atracción de la población y de actividades como la artesanía o el comercio. En cualquier caso este déficit de conocimiento arqueológico afecta con mayor o menor grado a todas los espacios laborales existentes en el interior del monasterio, y también por supuesto a las infraestructuras asociadas a estas dependencias. La excepción que confirma la regla la encontramos probablemente en los sistemas hidráulicos monásticos, que sí cuentan con varias monografías específicas y numerosos artículos que se ocupan sobre una temática para la que se puede considerar un estimable nivel de comprensión.

Un segundo paso adelante desde este planteamiento metodológico, una vez estudiados en profundidad cada uno de los ámbitos monásticos que han sido identificados, tendría que ser el análisis integral, comparativo y sistemático de la evolución de los edificios monásticos entre el Medievo y la Edad Moderna teniendo en cuenta las variables definidas, y estableciendo jerarquías a partir de la complejidad, la singularidad o la estandarización constructiva advertidas, así como detectando posibles modelos y patrones arquitectónicos en la configuración de estas dependencias extra claustrales. Para ello es necesario "medir" el monasterio en términos diferentes: por ejemplo a partir de su capacidad de almacenamiento y tratamiento de la producción agropecuaria, por su dotación tecnológica en un marco temporal determinado, o por su acondicionamiento y preocupación por la confortabilidad de la comunidad religiosa que ocupaba el edificio. $Y$ es que las estancias dedicadas al trabajo así como las infraestructuras desarrolladas en los edificios monásticos son elementos de la cultura material que funcionan como indicadores socioeconómicos, permitiéndonos realizar un análisis comparado de la riqueza material y del rango de sofisticación que alcanzaron y desarrollaron los diferentes monasterios, congregaciones y órdenes religiosas a lo largo del tiempo; por lo que en definitiva y en la mayoría de los casos son excelentes referencias del grado de enseñoramiento y del nivel de vida ostentado por cada comunidad monástica. Sírvanos en este sentido la cocina como modelo, la cual puede ser catalogada desde este enfoque considerando al menos seis variables diferentes:

1) Dotación de sistemas de fuego: hogares de suelo, fogones altos, número de fuegos y de hornos; sistemas de extracción de humos mediante campanas y chimeneas.

2) Dotación de sistemas de abastecimiento de agua: pozos, conducciones; medios para calentar el agua; existencia de pilas de agua y fregaderos.

3) Dotación de sistemas de evacuación de residuos; canalizaciones y alcantarillados; empleo de agua corriente en la evacuación.

4) Dotación de sistemas de iluminación (natural o artificial) y ventilación.

5) Dotación de sistemas de compartimentación interna especializada: según el tipo de alimentos; por temperatura y condiciones de conservación; existencia de despensas, sistemas de almacenamiento y conservación especializados; y antecocinas para la manipulación de los alimentos.

6) Dotación de mobiliario y utensilios especializados para el tratamiento de los alimentos.

Al igual que la cocina el resto de dependencias también son susceptibles de ser revisadas desde esta óptica, y así, otro ámbito de estudio que se nos antoja particularmente interesante podría ser el análisis de los medios que las diferentes comunidades claustrales dispusieron para asegurar su confortabilidad, mediante el empleo de sistemas de calefacción más o menos complejos, el diseño de circuitos de agua caliente, o el mayor o menor acondicionamiento de baños y letrinas. Por su parte una investigación en profundidad de los almacenes monásticos, de las cillas y las bodegas, sería un buen indicador de los comportamientos económicos de las diferentes órdenes y del celo que dispusieron en el manejo de la cosecha, ya que, como hemos comentado, la capacidad de transformación y conservación de los productos agropecuarios era un componente fundamental en la hacienda monástica, no solo para atender a las necesidades alimenticias de la familia sino también porque servían como medio de pago y como bienes de venta, permitiendo acceder a servicios y a productos suntuarios no generados en el propio monasterio.

$Y$ es que aunque habitualmente se tiene a los cistercienses como la orden que mejor organizó sus dominios, ${ }^{246}$ sobre todo mediante la implantación del exitoso sistema de

246 No cuestionando este axioma, fuertemente asentado por la historiografía francesa con estudios de referencia como el de R. Fossier (1949) o el de L. Pressouyre (1994), sí creemos que son modelos que no son exclusivos del Císter, y que también pueden ser identificados -con sus propias particularidades-y analizados en otras congregaciones y órdenes monásticas. 
granjas, no debemos olvidarnos que otras órdenes también planificaron con sumo cuidado la gestión de la producción en sus recintos y dominios, o la dotación de infraestructuras de trabajo y de servicio en sus edificios -hemos visto buenos ejemplos entre los benedictinos, los cartujos o los jerónimos-. En este sentido se ha podido observar en varios casos la existencia de un diseño tentacular de las infraestructuras monásticas -que ha sido poco estudiado hasta el momento-, de tal manera que en el edificio conventual se localizaban los almacenes principales (paneras, bodegas) pero a la vez existían otros de carácter secundario localizados en cada priorato, granja o en aquellas parroquias y aldeas donde cada monasterio concentraba sus propiedades. Un trasunto en definitiva del modelo cisterciense de granjas, ${ }^{247}$ pero aplicado por otras órdenes y mediante el cual la captación de la renta señorial se facilitaba y reforzaba acercando el granero al campesino.

Además, los monasterios constituyen elementos clave para entender la historia de la arquitectura, de la ingeniería y de la tecnología, y de los procesos de dotación de infraestructuras en sus edificios o en sus dominios agrarios. $Y$ es que por lo general las comunidades monásticas tuvieron mayor capacidad que otros estamentos para acceder a estos conocimientos -que se difundían entre las órdenes y las congregaciones-, ${ }^{248}$ lo que facilitó su control así como su progresiva introducción en los espacios agrarios con el objetivo de mejorar su explotación, encontrándose casi siempre detrás de todo ello el interés por aumentar los rendimientos productivos. ${ }^{249}$ De esta manera el análisis en profundidad de estos espacios de trabajo y de estas infraestructuras permitiría conocer mucho mejor cuestiones como el control de los medios de transformación de la producción o el monopolio de la tecnología, y en definitiva los comportamientos señoriales de estas comunidades religiosas. ${ }^{250}$

247 La configuración y morfología de las granjas cistercienses en la Península Ibérica ha sido perfectamente definida por F. Miguel Hernández (2012: 44) cuando escribe que "estaban constituidas por un conjunto de edificios que se disponían en torno a un patio y se delimitaban por una cerca: unos eran de uso económico (graneros, bodegas, lagares, hornos, molinos, que variaban según la función de la explotación) y otros domésticos (cocina, refectorio, dormitorio y capilla)". Por otra parte la excavación arqueológica de un monasterio cisterciense reconvertido en granja en Ancosa (Barcelona) se puede ver en Bolòs, J. y Mallart, L. 1986.

248 Hay que tener en cuenta la larga tradición de monjes arquitectos e ingenieros, y que las bibliotecas monásticas contaban con tratados de ingeniería, arquitectura, fortificación o matemáticas. En nuestro ámbito destaca por ejemplo la biblioteca del monasterio gallego de San Martín Pinario. Vid. al respecto el trabajo de Pita, P. 2011: 111.

249 Relacionada con esta dialéctica entre el monasterio y su entorno social se encuentra una posible imitatio por parte del estamento de la nobleza laica en lo que se refiere al uso, control y monopolio de la tecnología en los espacios productivos, una cuestión que ha sido también poco estudiada.

250 Un buen ejemplo es el control y monopolio del abastecimiento hidráulico por parte del monasterio jerónimo de Guadalupe (Cáceres), donde en el siglo Xv las obras de mejora del abastecimiento recayeron sobre los vecinos con un nuevo impuesto, provocando un alzamiento popular contra el monasterio. Además el monasterio podía decidir si otorgaba más agua para regadío a un vecino $u$ a otro en función de sus "buenos servicios", y decretaba la prohibición de pescar, lavar paños o construir molinos en el río, Vallés, J. A. 1998: 504-505.
También es necesario conocer más en detalle la topografía del recinto monástico, teniendo además en cuenta que la configuración de los espacios de trabajo extra claustrales pudieron presentar algunos patrones que se repiten a lo largo del tiempo aunque no respondan a modelos estáticos. $Y$ es que el monasterio debe de ser entendido como un edificio dinámico, en continua construcción, aunque a veces se presente como una foto fija, como resultados perfectos de una obra perfecta en un tiempo concreto. ${ }^{251}$ En este sentido resulta fundamental tener muy presente que la ubicación de los espacios de trabajo y de servicio en los monasterios fue cambiando a lo largo de los siglos, y la arqueología demuestra que donde en la Alta Edad Media había una huerta o un cementerio en el Tardomedievo podía levantarse una cilla, por ejemplo. De esta manera, y aunque existen ya algunos trabajos pioneros - principalmente para la época modernaes muy poco lo que sabemos sobre la distribución de las dependencias laborales, los almacenes, los establos, los cultivos o los jardines en el interior del recinto monástico, y de cómo estos fueron evolucionando a lo largo de los siglos y según qué criterios. Este desconocimiento afecta tanto a los grandes recintos de los monasterios rurales como a los pertenecientes a los conventos emplazados en las ciudades, de dimensiones más reducidas evidentemente y con mayores condicionamientos en su inserción en el entramado urbano.

A su vez hemos visto cómo en el monasterio medieval de pequeña y mediana entidad las actividades artesanales (hornos, secaderos, fraguas) podían localizarse en algunas de las pandas del claustro o en sus inmediaciones. En estos edificios la reforma de las fábricas en los siglos XVI y XVII supondrá un refinamiento monumental del claustro y el apartamiento de las actividades artesanales a patios de servicio y dependencias exentas dentro del recinto monástico. Sin querer caer en explicaciones fáciles -en el sentido de cuanto más moderno más complejo- sí se aprecia que desde el Medievo a la Edad Moderna el edificio conventual se suele ir especializando y por lo tanto diferenciando topográfica y funcionalmente. ${ }^{252}$ Así, algunas actividades que en la Edad Media se localizan en el claustro, como las relacionadas con el fuego, en época moderna tienden a ubicarse

251 Habitualmente, al ocuparnos de la historia de una arquitectura de cierta complejidad tratamos de establecer unos periodos de apogeo constructivo frente a otros de estancamiento o retroceso. A partir de esta conceptualización se definen unos paradigmas ideales en los que al cenobio románico le sucede el gran monasterio renacentista y a éste el monumental neoclásico. Si este método puede resultar válido como marco operativo, la microhistoria de un monasterio nos refleja la imagen de un edificio en el que se suceden fases de gran actividad edilicia con otras intermedias en las que el pulso constructivo no se detiene, sino que se redistribuye en numerosas labores de mantenimiento. También existen otras etapas donde no concurren grandes obras, e incluso tiene lugar la decadencia de algunas de las dependencias monásticas. Pero así todo resulta difícil imaginarse un solo año en la historia de un monasterio en el que no se haya comprado una hemina de cal. Y todo ello respondiendo a un contexto histórico determinado, donde la obra arquitectónica adquiere pleno sentido, ya que como ya hemos comentado la historia constructiva de un monasterio se explica en gran medida a partir de su historia institucional y económica.

252 En cualquier caso hay que tener muy presente que la materialización de estos espacios de trabajo variaba dependiendo de cada orden religiosa, y también de la rigidez de la clausura a lo largo de los diferentes periodos históricos. 
en alas anexas, patios de servicio o edificios exentos. Nos referimos por ejemplo a las ferrerías, las panaderías o los secaderos de alimentos, que provocaban humos y malos olores, además del temido peligro de incendio.

También se ha observado que una parte considerable de estas construcciones de trabajo y de servicio se definen como arquitecturas en madera, bien total bien parcialmente, y tanto en época medieval como moderna. $Y$ es que no podemos olvidar que buena parte de las estancias extra claustrales medievales, y a veces también las de época moderna, estaban construidas con maderos hincados sobre el terreno o dispuestos sobre zócalos de piedra. Fundamentalmente nos estamos refiriendo a dependencias de carácter doméstico o de servicio, artesanales o almacenes, que ocupaban el recinto monástico en torno al claustro; ${ }^{253}$ pero tampoco debemos olvidar que no todos los claustros medievales estaban completamente cerrados con galerías y arcadas en sillería, y que éstas podían convivir con algunas alas resueltas mediante pabellones de madera o con técnicas mixtas combinando piedra y madera. Por este motivo creemos que estas cuestiones deberían de ser tenidas muy en cuenta en las futuras investigaciones arqueológicas sobre la morfología, las fases constructivas, la caracterización edilicia, y los procesos de petrificación de los monasterios, tanto en lo que se refiere a las dependencias de servicio como también a las principales situadas en el claustro.

Además hemos podido comprobar cómo fue cambiando entre la época medieval y moderna el tipo de actividades productivas y artesanales que se realizaban en el interior del recinto monástico, circunstancia que en gran medida se explica por la secularización de una parte de la producción artesanal durante el Bajomedievo y la Edad Moderna, y que anteriormente era llevada a cabo en los monasterios bien por la propia familia monástica bien por artesanos itinerantes. Nos estamos refiriendo por ejemplo a la elaboración de campanas de bronce o de pergaminos para los manuscritos, aunque en cualquier caso aún queda mucho por investigar y resolver con respecto a la tesis tradicional que contempla la evolución desde un monasterio altomedieval más autárquico hacia un monasterio tardomedieval y moderno con mayor inserción en las redes comerciales y de intercambio.

En definitiva, y retomando lo que comentábamos al principio de este trabajo, la investigación arqueológica tiene todavía un largo camino por recorrer en el interior de estos recintos si pretende revisar su conocimiento de la arquitectura conventual, edificio por edificio, y no solo en función de la historia institucional de cada congregación sino atendiendo también a la historia económica del señorío monástico, y trasladando su punto de vista a los ámbitos laborales que ocuparon aquellos trabajadores al servicio del claustro.

253 Una buena representación la encontramos en los edificios en madera -algunos temporales y otros de carácter más estable- documentados en los siglos XII y XIII en Inglaterra en la abadía de Elstow o el priorato de Grove. Se trata de hospederías, letrinas, panaderías, cocinas, salas de cocción o de secado, graneros, establos o lavaderos, Baker, D. y Baker, E. 1989.

\section{BibLIOgRAFÍA}

Abad Castro, C. 1998. "El pabellón de monjes", en Bango Torviso, I. (dir.), Monjes y monasterios. El cister en el medievo de Castilla y León, Valladolid: 187-235.

Abad Castro, C. 1998b. "La panda del refectorio", en Bango Torviso, I. (dir.), Monjes y monasterios. El cister en el medievo de Castilla y León, Valladolid: 237-254.

Abad Zardoya, C. 2010. "Herramientas curiosas para cosas particulares y extraordinarias. Tecnología, espacios y utillaje en la cocina histórica española", en Moyano, I. y Simón Palmer, C. (coords.), La cocina en su tinta. Libros e imágenes en la Biblioteca nacional de España, Madrid: 85-117.

Abal, A. 2008. "El monasterio de San Lorenzo de Carboeiro: intervenciones en el patrimonio y teoría de la restauración", Abrente 40-41: 75-106.

Abascal, J. M. y Cebrián, R. 2009. Los viajes de José Cornide por España y Portugal de 1754 a 1801, Alicante.

Adán Álvarez, G. 2007. "Estudios arqueológicos en el monasterio de San Salvador de Cornellana (1998 a 2001)", Excavaciones arqueológicas en Asturias 1999-2002 o 5, Oviedo: 335-342.

Adán Álvarez, G. y Álvarez-Lao, D. 2002. "The medieval cattle raising and their use in Asturias (Spain): a city, a monastery and a castle", 3rd International Conference of Medieval and Later Archaeology. Medieval Europe, Basilea: 65-69.

Aguelo i Mas, J. 2002. "Arqueologia i conjunts monàstics: recull bibliogràfic", Il Congrés d'Arqueologia Medieval $i$ Moderna a Catalunya, Sant Cugat del Vallès: 169-182.

Aguelo, J., Artigues, P. LI., Sardá, M. y Vila, J. Mā 1998a. "Vestigis preromànics i alt-medievals de l'ala NE al monestir de Sant Cugat del Vallès (el Vallès Occidental)", I Congrés d'Arqueologia Medieval i Moderna a Catalunya. 15 anys d'intervencions arqueològiques: mancances i resultats, Igualada: 350-355.

Aguelo, J., Artigues, P. LI., Sardá, M. y Vila, J. Ma 1998b: "Una nau gòtica inacabada al monestir de Sant Cugat del Vallès", I Congrés d'Arqueologia Medieval i Moderna a Catalunya. 15 anys d'intervencions arqueològiques: mancances i resultats, Igualada: 432-440.

Aguerri Martínez, F., Casabona Sebastián, J. F. y Ibarguen Soler, J. 1996. "La infraestructura hidráulica del monasterio de Rueda y su inclusión en el plan director de restauración", en Mascarenhas, J. M. P. B. de, Abecasis, M. H. y Ferreira Jorge, V. (eds.): Hidráulica monástica medieval e moderna, Lisboa: 187-206.

Álvarez Castrillón, J. A. 2009. El monasterio de Santa María de Villanueva de Oscos. Historia y fuentes, Villanueva de Oscos.

Álvarez Merayo, I. 2008. «Excavación arqueolóxica das estructuras constatadas no control da 3 a fase de restauración do mosteiro de Ferreira de Pantón (Lugo)», Actuacións arqueolóxicas. Año 2006, Santiago de Compostela: 91-92.

Amores Carredano, F. de, Díaz Sánchez, A. y Hunt Ortiz, M. 1989. "Los sistemas hidráulicos de la Cartuja de Santa 
María de las Cuevas de Sevilla: La Noria norte», El Agua en zonas áridas: Arqueología e Historia. I Coloquio de Historia y Medio físico, Almería: 931-948.

Andrés, G. de 1976. «Inventario de documentos sobre la construcción y ornato del Monasterio del Escorial existentes en el Archivo de su Real Biblioteca», Archivo Español de Arte, Anejo, Madrid.

Antequera Luengo, J. J. 2012. De la cocina cartujana, Sevilla.

Antón, F. 1942. Monasterios medievales de la provincia de Valladolid, Valladolid.

Archibald, E. 2012. «Bathing, Beauty and Christianity in the Middle Ages", Insights 5, Universidad de Durham: 1-16.

Artigues i Conesa, P. LI. 2002. "El monestir de Sant Cugat del Vallès. L'evolució arquitectónica a partir de I'arqueologia", II Congrés d'Arqueologia Medieval i Moderna a Catalunya, Sant Cugat del Vallès: 18-28.

Aubert, M. 1943. L'architecture cistercienne en France, 2 vols., Paris.

Augenti, A., Begnozzi, I., Bondi, M., Cirelli, E., Ferreri, D., Malaguti, C. y Scozzari, P. 2012. "Il monastero di San Severo a Classe: risultati delle campagne di scavo 2006-2011", en Redi, F. y Forgione, A. (eds.): VI Congreso Nazionale di Archeologia Medievale, L'Aquila: 238-245.

Baker, D. y Baker, E. 1989. "Research designs: timber phases and outbuildings with special reference to Elstow abbey and Grove priory, Bedfordshire, and a note about the availability of information", Gilchrist, R. y Mytum, $\mathrm{H}$. (eds.): The Archaeology of Rural Monasteries, British Archaeological Reports, British Series 203, Oxford: 261-275.

Balado Pachón, A. y Escribano Velasco, C. 2010. Guía del Císter en Castilla y León, Valladolid.

Balboa de Paz, J. A. 1997. El monasterio de Carracedo, León.

Baldassarri, M., Del Greco, S., Giorgio, M. y Naponiello, G. 2012. "Il monastero di Montescudaio (Pi): un ceobio femminile nell'organizzazione territoriale della bassa Val di Cecina medievale", en Redi, F. y Forgione, A. (eds.): VI Congresso Nazionale di Archeologia Medievale, L'Aquila: 470-476.

Bango Torviso, I. 1994. "Arquitectura y escultura", Historia del Arte de Castilla y León. II. Arte románico, Valladolid: 9-212.

Bango Torviso, I. 1998a. "El monasterio", Bango Torviso, I. (dir.): Monjes y monasterios. El cister en el medievo de Castilla y León, Valladolid: 67-97.

Bango Torviso, I. 1998b "La topografía del ora et labora", Bango Torviso, I. (dir.): Monjes y monasterios. El cister en el medievo de Castilla y León, Valladolid: 99-103.

Bango Torviso, I. 1998c "El claustro y su topografía", Bango Torviso, I. (dir.): Monjes y monasterios. El cister en el medievo de Castilla y León, Valladolid: 157-165.

Barreda, Fr. I. de 1917. Oña y su real monasterio, Madrid.

Blanco Rotea, R. y Fernández Rodríguez, B. 2013. Análisis estratigráfico de los alzados del monasterio de Santa María de Melón (Melón, Ourense), www.digital.csic.es.
Bohigas Roldán, R., Campuzano Ruiz, E. y González Echegaray, J. 2008. "La intervención arqueológica en Santa María La Real de Piasca (Cabezón de Liébana) (20002002)", Actuaciones arqueológicas en Cantabria 2000-2003, Santander: 179-184.

Bolòs i Masclans, J. y Mallart i Raventós, L. 1986. La granja cistercenca d'Ancosa (La Llacuna, Anoia). Estudi dels edificis i dels materials trobats durante les excavacions (1981-1983), Barcelona.

Bond, C. J. 1989. "Water Management in the Rural Monastery", Gilchrist, R. y Mytum, H. (eds.): The Archaeology of Rural Monasteries, British Archaeological Reports, British Series 203, Oxford: 83-111.

Bond, C. J. 2001. "Production and Consumption of Food and Drink in the Medieval Monastery", en Keevill, G., Aston, M. A. y Hall, T. (eds.): Monastic Archaeology: Papers on the Study of Medieval Monasteries, Oxford: 54-87.

Bonilla Rodríguez, A. 2008. "Proxecto básico e de execución Restauración do mosteiro de S. Lourenzo de Carboeiro, 2ㅇ fase, Silleda (Pontevedra)", Actuacións arqueolóxicas. Año 2006, Santiago de Compostela: 89.

Braunfels, W. 1975. La arquitectura monacal en Occidente, Barcelona.

Bräuning, A. y Stelzle-Hüglin, S. 2002. "Drei Heizanlagen des ehemaligen Franziskanerklosters in Ulm", en Röber, R. (ed.): Mittelalterliche Öfen und Feuerungsanlagen, Stuttgart: 35-54.

Bully, S. y Sapin, C. 2013. "Au seuil du cloître: la présence des laïcs (hôtelleries, bâtiments d'accueil, activités artisanales et de services) entre le Ve et le xII ${ }^{\mathrm{e}}$ siècle", Bulletin du centre d'études médiévales d'Auxerre, 17.1., http://cem. revues.org: 1-2.

Busquets, C. y Pastor, I. 2002. "Una transformació de l'espai urbà a la Barcelona de finals del segle XVI. La construcció del convent de carmelites descalces", Il Congrés d'Arqueologia Medieval i Moderna a Catalunya, Sant Cugat del Vallès: 147-153.

Cantos Rueda, J. A. 2007. "Noves aportacions a la problemàtica de les galeries subterrànies d'època moderna", III Congrés d'arqueologia medieval i moderna a Catalunya, II: 717-720.

Carannante, A., Chilardi, S., Fiorentino, G., Pecci, A. y Solinas, F. 2007. "Le cucine di San Vincenzo al Volturno. Ricostruzione funzionale in base ai dati topografi ci, strutturali, bioarcheologici e chimici", en De Rubeis, F. y Marazzi, F. (eds.): Monasteri in Europa occidentale (secoli VIII-XI): topografia e strutture, Roma: 487-506.

Carrillo, J. 1616. Relación histórica de la Real Fundación del Monasterio de las Descalzas de S. Clara de la Villa de Madrid. Madrid.

Carver, M. 2004. "An lona of the East: The Early-medieval Monastery at Portmahomack, Tarbat Ness", Medieval Archaeology 48: 1-30.

Casas Castells, E. 2005. "Tipología de las iglesias y estancias claustrales en los monasterios femeninos cistercienses de Castilla y León. Estado de la cuestión", Actes del Primer 
Curs-Simposi sobre el Monaquisme Cistercenc. El Cister: Poder i Espiritualitat, Santes Creus: 99-151.

Castiñeiras González, M. A. 2006. "San Estevo de Ribas de Sil revisitado: nuevos hallazgos e hipótesis sobre el monasterio medieval", Porta da aira: revista de historia del arte orensano 11: 53-90.

Cerro Herranz, Mạ. F. y Sánchez Rubio, Mạ. A. 1984. "La elaboración y consumo de vino en el monasterio de Guadalupe en la Baja Edad Media", Norba. Revista de Historia 5: 95-115.

Cimadevilla Rodríguez, M. y Prieto Vergara, M. A. 2004. "Palomares en Asturias", B.R.I.D.E.A. 163, Oviedo: 53-76.

Conant, K. J. 1968. Cluny, les églises et la maison du chef d'ordre, Mâcon.

Coppack, G. 1989. "Thornholme priory: the development of a monastic outer court", Gilchrist, R. y Mytum, H. (eds.): The Archaeology of Rural Monasteries, British Archaeological Reports, British Series 203, Oxford: 185-222.

Coppack, G. 1996. "The contribution of the carthusians to monastic hydraulics: the evidence from England", Mascarenhas, J. M. P. B. de, Abecasis, M. H. y Ferreira Jorge, V. (eds.): Hidráulica monástica medieval e moderna, Lisboa: 51-63.

Correia Dias, C. y Ferreira Jorge, J. 1996. "Rede hidráulica da abadia cisterciense de Sao Cristóvao de Lafoes", Mascarenhas, J. M. P. B. de, Abecasis, M. H. y Ferreira Jorge, V. (eds.): Hidráulica monástica medieval e moderna, Lisboa: 227-240.

Cunha Leal, C. y Almeida Ferreira, M. 2006-2007. "Cuidados de higiene e de saúde em uma comunidade monástica do século XVII: o caso do Mosteiro de Santa Claraa-Velha de Coimbra", Portugalia XXVIII: 89-117.

Currie C. K. 1989. "The role of fishponds in the monastic economy", Gilchrist, R. y Mytum, H. (eds.): The Archaeology of Rural Monasteries, British Archaeological Reports, British Series 203, Oxford: 173-184.

De la Casa, C., Domènech, M. y Menchón, J. 1998. “Los hijos del agua. Anotaciones sobre la hidráulica cisterciense", Bango Torviso, I. (dir.): Monjes y monasterios. El cister en el medievo de Castilla y León, Valladolid: 43-46.

Díaz Ibáñez, J. 1995. "Santa María de Monsalud. Reconstrucción histórica de un cenobio cisterciense", Cistercium 201: 357-473.

Domínguez Sánchez. S. 2013. “Oficios y artesanos medievales en el monasterio leonés de Vega", Hispania Sacra LXV Extra II: 33-57.

Durany, M. 1976. San Pedro de Montes: el dominio de un monasterio benedictino de El Bierzo (siglos IX al XIII), León.

Erasún Cortés, R. 2008. "A fundição de sinos no Mosteiro de Santa Maria de Pombeiro", Oppidum no especial: 131-149.

Escalona, R. y Pérez, J. 1782. Historia del Real Monasterio de Sahagún, Madrid.

Eogan, G. 2012. The Archaeology of Knowth in the First and Second Millennia $A D$, Dublin.
Fernández Cortizo, C. 2005. "La Orden de San Benito en la Galicia de la Época Moderna: La reforma de la Congregación de Castilla y las visitas generales", en López Vázquez, J. M. (coord.): Opus Monasticorum, Santiago de Compostela: 23-61.

Fernández de la Cuesta, I. 2003. "La alegría en el monasterio. Las Carmina Goliardescos y la vida monástica, García de Cortázar, J. A. (coord.): Vida y muerte en el monasterio románico, Aguilar de Campoo: 203-221.

Ferreira Jorge, V. 1996. "Sistema hidráulico do convento dominicano de Santa Maria da Vitória (Batalha)", Mascarenhas, J. M. P. B. de, Abecasis, M. H. y Ferreira Jorge, V. (eds.): Hidráulica monástica medieval e moderna, Lisboa: 105-125.

Floriano Cumbreño, A. C. 1950. El Libro Registro de Corias, 2 tomos, Oviedo.

Florido Trujillo, G. 1996. Hábitat rural y gran explotación en la depresión del Guadalquivir, Sevilla.

Fontes, L. 2005. Sao Martinho de Tibaes. Um sítio onde se fez um mosteiro. Lisboa.

Fossier, R. 1949. "La vie économique de l'abbaye de Clairvaux des origines à la fin de la guerre de Cent Ans", Positions des thèses de l'Ecole des Chartes: 57-63.

García Álvarez-Busto, A. 2011. Arqueología de los monasterios en Asturias: San Juan Bautista de Corias, Universidad de Oviedo, tesis doctoral inédita.

García Álvarez-Busto, A. 2013 "El molino de cacao del monasterio de Corias (Asturias). Documentación histórica y análisis arqueológico", Actas del 8 Congreso Internacional de Molinología, Tui: 535-554.

García Álvarez-Busto, A. y Adán Álvarez, G. 2001. Excavación arqueológica en el monasterio de Cornellana. Campaña de 2001, en Adán Álvarez. G. (dir.): Proyecto Arqueológico Cornellana 2001, Consejería de Cultura y Turismo, Oviedo.

García de Cortázar, J. A. 1969. El dominio del monasterio de San Millán de la Cogolla (siglos X al XIII). Introducción a la historia rural de Castilla altomedieval, Salamanca.

García Flores, A. 1999. “Aproximación a las campañas constructivas del monasterio cisterciense de Valbuena (Valladolid)", Actas del V Congreso de Arqueología Medieval Española, vol. 1, Valladolid: 293-301.

García García, E. 1980. San Juan Bautista de Corias. Historia de un señorío monástico asturiano (siglos $X-X V$ ), Oviedo.

García Gazólaz, J., Martín Carbajo, M. A., Fernández Orallo, E., Marcos Contreras, G. J., Misiego Tejeda, J. C. y Sanz García, F. J. 2011. "La iglesia de San Pedro de La Rúa de Estella (Navarra): intervención arqueológica integral”, Trabajos de Arqueología de Navarra 23: 175-274.

García Guinea, M. A. 1980. "Arqueología y comunicación", Boletín de la ANABAD 30-2: 225-233.

García Verdugo, V. 1851. "Economía doméstica", en V.V.A.A., Instrucción para el pueblo. Cien tratados sobre los conocimientos más indispensables, T. II, Madrid: 3105-3136. 
Garralda García, A. 1970. Avilés, su fe y sus obras, Avilés.

Gautier-Dalche, J. 1965. "Le domaine du monastère de Santo Toribio de Liébana: formation, structure et modes d'explotation", Anuario de Estudios Medievales 2: 63-117.

Gelichi, S., Alberti, A. y Dadà, M. 2005. “'L'indagine archeologica del monastero di San Michele alla Verruca: la periodizzazione della sequenza insediativa", en Alberti, A. y Gelichi, S. (eds.), L'aratro e il calamo. Benedettini e Cistercensi sul Monte Pisano. Dieci anni di archeologia a San Michele alla Verruca, Pisa: 63-127.

Gilchrist, R. y Mytum, H. 1989. The Archaeology of Rural Monasteries, British Archaeological Reports, British Series 203, Oxford: 261-275.

Gilchrist, R. y Sloane, B. 2005. Requiem. The medieval monastic cemetery in Britain, Londres.

Godelier, M. 1973. "Modes des productions, rapports de párente et structures démographiques", La Pensée 172: 187-220.

Goicolea Zala, J. y Muñoz de San Pedro, G. R. 1996. "The water supply system of the Yuste monastery till the death of the emperor Charles V", Mascarenhas, J. M. P. B. de, Abecasis, M. H. y Ferreira Jorge, V. (eds.): Hidráulica monástica medieval e moderna, Lisboa: 65-82.

Gómez Navarro, S. 2010. "Vida cotidiana de monjas y religiosas en la España Moderna a través de sus contabilidades. El convento cordobés de Santa Ana a fines del Antiguo Régimen", Revista de Historia Social y de las Mentalidades 14-2, Santiago de Chile: 103-136.

González Pérez, J. R. y Xandri Solè, J. 2002. “El procés de recuperació de l'antiga casa trinitària d'Avinganya (Seròs, el Segrià), Il Congrés d'Arqueologia Medieval i Moderna a Catalunya, Sant Cugat del Vallès: 49-64.

González Zymla, H. 2010. “Arquitectura militar medieval en el Real Monasterio Cisterciense de Santa María de Piedra: el castillo Malavella, la torre puerta y la cerca murada", Anales de Historia del Arte 20: 51-85.

Greene, J. P. 2001. "Strategies for Future Research and Site Investigation", en Keevill, G., Aston, M. y Hall, T. A. (eds.): Monastic Archaeology: papers on the study of medieval monasteries, Oxbow: 4-8.

Hall, J. y Kratzke, C. 2005. Sepulturae Cistercienses, Citeaux. Comentarii Cistercienses 56 fasc. 1-4, Forges-Chimay.

Hayter, S. 2013. The Archaeological record of the Cistercians in Ireland 1142-1541, www.ancient-egypt.co.uk.

Herremans, D. y Coomans, Th. 2013. “'Labbaye de moniales cisterciennes de Clairefontaine (Luxembourg). Synthèse archéo-historique des quatre phases de construction, XIII-XVIII siècle", Bulletin Monumental Société Française d'Archéologie 171-2: 117-139.

Kawamura, Y. 2005. "Melchor de Velasco, tracista de la ampliación barroca del monasterio de San Vicente de Oviedo", BSAA arte LXXI: 193-213.

Kawamura, Y. 2006. "Traída de agua para el monasterio de Santa María de la Vega de Oviedo, proyecto del arquitecto Melchor de Velasco", Liño 12: 89-97.
Ladra, L. 2012. "Intervención arqueolóxica no Mosteiro de Samos (Lugo): resultados preliminares", Anuario Brigantino 35: 39-58.

Leroux-Dhuys, J. F. 1999. Las abadías cistercienses en Francia y Europa. Madrid.

Linage Conde, A. 2007. La vida cotidiana de los monjes en la Edad Media, Madrid.

Linarejos Cruz, M. 2006. "Recuperación de un paisaje de escala doméstica. Huertas y jardines en el monasterio de Santa María de El Paular, Rascafría (Madrid)", Bienes culturales: revista del Instituto de Patrimonio Histórico Español 6: 163-170.

López Álvarez, X. 1994. Las abejas, la miel y la cera en la sociedad tradicional asturiana, Oviedo.

López de Guereño Sanz, Mạ T. 1996. “El monasterio premonstratense de San Salvador de Urdax. Génesis y evolución histórico-artística", Príncipe de Viana 207: 19-60.

López de Guereño Sanz, Mạ T. 1998. “La cilla, el pasaje de conversos y el locutorio del cillero", Bango Torviso, I. (dir.): Monjes y monasterios. El cister en el medievo de Castilla y León, Valladolid: 255-264.

López de Guereño Sanz, Mạ T. 1998b. “Las dependencias extraclaustrales”, Bango Torviso, I. (dir.): Monjes y monasterios. El cister en el medievo de Castilla y León, Valladolid: 265-284.

López de Guereño Sanz, Mã T. 2003. “Las dependencias extraclaustrales en los monasterios cistercienses y premonstratenses: espacios y funciones", García de Cortázar, J. A. (coord.): Vida y muerte en el monasterio románico, Aguilar de Campoo: 87-109.

López García, J. M. 1982. “Economía monástica y sociedad rural en Valladolid durante el Antiguo Régimen: La Real Cartuja de Nuestra Señora de Aniago", Revista de Historia Moderna. Anales de la Universidad de Alicante 2: 83-134.

López García, J. M. 1990. La transición del feudalismo al capitalismo en un señorío monástico castellano: el abadengo de la Santa Espina (1147-1835), Valladolid.

López López, J. M. 2001. Sistemas hidráulicos en los monasterios cistercienses de la Corona de Aragón: Arquitectura y Sostenibilidad, Tesis Doctorales, Universidad de Alicante, www.eltallerdigital.com.

López Mullor, A. y Caixal Mata, A. 1998. "Resultats dels darrers treballs d'excavació al monestir de Sant Llorenç prop Bagà", I Congrés d'Arqueologia Medieval i Moderna a Catalunya. 15 anys d'intervencions arqueològiques: mancances i resultats, Igualada: 472-488.

López Mullor, A., Caixal Mata, A. y Vila Carabasa, J. M. 2006. "El recinte medieval del monestir de Sant Llorenç prop Bagà. Campanyes arqueològiques dels anys 2000-2004", III Congrés d'Arqueologia Medieval i Moderna a Catalunya, Sabadell: 585-604.

Lyons, S. 2012. Bective Abbey Project E4028 - Season 2010 \& Season 2011 Results from Archaeobotanical \& Charcoal Analysis, http://bective.files.wordpress.com.2012.pdf.

Llopis Agelán, E. 1980. Las economías monásticas al final del Antiguo Régimen en Extremadura, Madrid. 
Maines, C. y Bonde, S. 1996. “Water management and garden design at Saint-Jean-des-Vignes in the sixteenth century", Mascarenhas, J. M. P. B. de, Abecasis, M. H. y Ferreira Jorge, V. (eds.): Hidráulica monástica medieval e moderna, Lisboa: 269-297.

Manso Porto, C. 2002. "El monasterio de Santa María La Real de Oia. Estudio histórico-artístico", Cuadernos de Estudios Gallegos XLIX-115: 251-306.

Martín Prado, P. y Aranda Palacios, A. 2007. «Rehabilitación del antiguo convento de La Merced de Ciudad Real como museo», en Millán Martínez, J. M. y Rodríguez Ruza, C. (coords.): Arqueología de Castilla-La Mancha, Cuenca: 207-229.

Martínez de Aguirre, J. 1992. «El monasterio como ámbito de la vida cotidiana : espacios y funciones", Codex aquilarensis: Cuadernos de investigación del Monasterio de Santa María la Real 6: 75-98.

Martínez Peñarroya, J. 1998. «El Convento franciscano de San Gil El Real de Madrid», en Andreu, E., Palacios, J. (coords.): La Plaza de Oriente. Arqueología y Evolución urbana, Madrid: 121-141.

Martínez Vega, A. 1994. El monasterio de Santa María de la Vega, Oviedo.

Martínez Vega, A. 1997. Santa María de Villamayor y San Martín de Soto. Los monasterios medievales del valle del Piloña, Infiesto.

Mascarenhas, J. M. P. B. de, Abecasis, M. H. y Ferreira Jorge, V. 1996. Hidráulica monástica medieval e moderna, Lisboa.

Mataró i Pladesala, M. 2002. "El monastir de Sant Pere de Rodes (El Port de la Selva, Alt Empordà), II Congrés d'Arqueologia Medieval i Moderna a Catalunya, Santa Cugat del Vallès: 65-77.

Matesanz Vera, P. 1993. “El monasterio de Santa María la Real (Aguilar de Campoo, Palencia). Arqueología y Arquitectura", Boletín de Arqueología Medieval 7: 95-116.

Mendes Pinto, M. 2011. Mosteiro de Santa Maria de Pombeiro. Arqueologia. Cámara Municipal de Felgueiras.

Menéndez Pidal, G. 1986. La España del siglo XIII leída en imágenes, Madrid.

Miguel Hernández, F. 1989. “El sistema hidráulico en un monasterio cisterciense. Santa María de Carracedo (León)", I Coloquio de Historia y Medio Físico. El agua en zonas áridas: arqueología e historia, Almería: 899-920.

Miguel Hernández, F. 2012. «Religiosidad y edificios religiosos en la España cristiana (siglos XII-XV). Una síntesis desde la arqueología», Territorio, sociedad y poder. Revista de estudios medievales 7: 9-62.

Miguel Hernández, F. y Marcos Villán, M. A. 1997. "Arqueología del horno de fundición de campanas del convento de San Francisco Extrapontem de Zamora", Las campanas. Cultura de sonido milenario. Actas del I Congreso Nacional, Santander: 439-456.

Mínguez Fernández, J. Mạ 1980. El dominio del monasterio de Sahagún en el siglo $X$, Salamanca.
Mitchell, J. 1996. "Monastic Guest Quarters and Workshops: The Example of San Vincenzo al Volturno", en Sennhauser, H. R. (ed.): Wohn- und Wirtschaftsbauten frühmittelalterlicher Klöster, Zürich: 127-155.

Morales Muñiz, A. 1994. La dieta de los monjes cartujos de Santa María de Las Cuevas, El Paular.

Moreta Velayos, S. 1971. El monasterio de San Pedro de Cardeña. Historia de un dominio monástico castellano (9021338), Salamanca.

Moreta Velayos, S. 1974. Rentas monásticas en Castilla. Problemas de método, Salamanca.

Moro Barreñada, J. Ma 1976. “La desamortización de los bienes municipales en Asturias en la segunda mitad del siglo XIX", B.I.D.E.A. 88: 627-679.

Munita Loinaz, J. A. 1995. El monasterio de La Oliva en la Edad Media (siglos XII al XVI). Historia de un dominio cisterciense navarro, Vitoria Gasteiz.

Muñiz López, I. 2001. Memoria del análisis territorial del monasterio de San Salvador de Cornellana (Salas), en Adán Álvarez, G., Monasterio de San Salvador de Cornellana. Arqueología 2001, Consejería de Cultura y Turismo, Oviedo.

Muñiz López, I. y García Álvarez-Busto, A. 2009. “El monasterio de Santa María de Raíces (Castrillón): intervención arqueológica de 2005 y propuesta interpretativa", Excavaciones Arqueológicas en Asturias 2003-2006, Oviedo: 243-254.

Muñoz Jiménez, J. M. y Schnell Quiertant, P. 2006. “Los hornos de cal del Zancao en Vegas de Matute (Segovia)", Re Metallica 6-7: 75-82.

Musset, J. 1984. "Le droit de colombier en Normandie sous l'Ancien Régime”, Annales de Normandie, 34e année 1: 51-67.

Nuño González, J. 2008. "Las bodegas medievales de Pampliega (Burgos)", Codex Aquilarensis 24: 8-30.

Olcoz, S. 2008. Fitero Cisterciense. Del monasterio a la villa (siglos XII-XV), Tudela.

Padilla Lapuente, J. I. 1980. “Aportación al estudio de la estructura económica de un monasterio altomedieval. Un prototipo: Sant Pere de Grau d'Escales", Acta histórica et archaeologica mediaevalia 1: 197-224.

Pallares, Ma C. 1979. El monasterio de Sobrado: un ejemplo de protagonismo monástico en la Galicia medieval, A Coruña.

Paz González, D. 1991. El monasterio de Santa María de Villanueva de Oscos: de la reforma a la exclaustración, Oviedo.

Pedregosa Megías, R. J. y Martínez Novillo Moya, A. 2007. "El convento de San Antonio, Montefrío (Granada). Estudio histórico-arqueológico a partir del análisis de las estructuras emergentes", Antiquitas 18-19: 237-263.

Pérez-Embid Wamba, F. J. 1986. El Císter en Castilla y León. Monacato y dominios rurales (Siglos XII-XV), Salamanca.

Pérez-Embid Wamba, F. J. 2011. “Los cistercienses y el agua. El ejemplo de las abadías francesas y españolas”, en Abellán 
Pérez, J. y Castañeda Fernández, V. (coords.), Homenaje al profesor Antonio Caro Bellido, vol. 2, Cádiz: 305-314.

Pernoud, R. y Herscher, G. 1996. Jardins de monastères. Arles: Actes Sud.

Pita Galán, P. 2011. “Los arquitectos religiosos y las obras de ingeniería”, en Huerta, S., Gil Crespo, I., García, S. y Taín, M. (eds.): Actas del VII Congreso Nacional de Historia de la Construcción, Madrid: 1109-1118.

Pressouyre, L. 1994. L’Espace cistercien, París.

Real Jardín Botánico 1797. Semanario de Agricultura y Artes dirigido a los párrocos, T. I, Madrid.

Redi, F. y Petrella, G. 2007. Dal fuoco all'aria. Tecniche, significati e prassi nell'uso delle campane dal Medioevo all'Età Moderna, Pisa.

Revuelta González, M. 1976. La Exclaustración (18331840), Madrid.

Ríos González, S. 2014. "El foso para fundir campanas de la antigua iglesia de los PP. Franciscanos de Avilés (actual parroquial de San Nicolás de Bari)", Nailos. Estudios Interdisciplinares de Arqueología 1: 210-223.

Riu-Barrera, E. 1998. “Implantació territorial i forma arquitectónica dels monestirs de la Catalunya Comtal (s. (X-XI)", I Congrés d'Arqueologia Medieval i Moderna a Catalunya. 15 anys d'intervencions arqueològiques: mancances i resultats, Igualada: 294-307.

Riu-Barrera, E. 2002. "L'arqueologia dels monestirs en els darrers temps. Aportacions i problemes", I/ Congrés d'Arqueologia Medieval i Moderna a Catalunya, Santa Cugat del Vallès: 185-192.

Ríu Ríu, M. 1982. Acta historica et archaelogica mediaevalia. Annex Núm.: 1 Necròpolis i sepultures medievals de Catalunya, Barcelona.

Ríu Ríu, M. 1989. L'arqueologia medieval a Catalunya, Barcelona.

Rodríguez Díaz, E. 2001. “La industria del libro manuscrito en Castilla: fabricantes y vendedores de pergaminos (ss. XII-XV), Historia, instituciones, documentos 28: 313-351.

Rodríguez López, A. 1907. El Real Monasterio de las Huelgas de Burgos y el Hospital del Rey, Burgos.

Rodríguez Untoria, S. y Fernández del Cerro, J. 2011. “De casa a convento: el Monasterio de San Clemente de Toledo", en Izquierdo Benito, R. y Passini, J. (eds.): La ciudad medieval: de la casa principal al palacio urbano, Toledo.

Ruiz de la Peña Solar, J. I. 1977. Historia de Asturias. Baja Edad Media 5, Salinas.

Saavedra Fernández, P. 1987. "La economía del Monasterio de Carracedo; ca. 1700-1834", Studia historica. Historia Moderna 5: 241-282.

Salazar Ortiz, N. 2006. "Primeres intervencions arqueològiques al monestir de Santa María de Lavaix (anys 20032005), III Congrés d'Arqueologia Medieval i Moderna a Catalunya, Sabadell: 807-814.

Salazar Ortiz, N. 2010. "Noves dades arqueològiques sobre l'antiga sala capitular (segles XIII-XIV) del monastir de Ripoll (Ripollès)", Desenes Jornades d'Arqueología de les Comarques de Girona, Arbúcies: 547-552.

Sales Carbonell, J. 2013. "Fabricando pergamino durante la antigüedad tardía. Notas arqueológicas para los monasterios de Hispania", Augustinianum 53-2: 469-500.

Salvador Velasco, M. y Viñé Escartín, A. I. 2008. "Excavaciones arqueológicas en diferentes dependencias domésticas y religiosas del monasterio", en Larrén Izquierdo, H. (coord.): Moreruela: un monasterio en la historia del Císter, Junta de Castilla y León: 403-425.

San Gregorio Hernández, D., Enríquez Sánchez, E., Martín Rodríguez, E. y Cruz Sánchez, P. J. 2009. “Algunas notas sobre el monasterio cisterciense de San Andrés de Arroyo (Santibáñez de Ecla, Palencia) a través de sus documentos arqueológicos", Estudios del Patrimonio Cultural. Revista digital 2, www.sercam.es: 27-48.

Sanjust i Latorre, C. 2010. L'Obra del Reial Monestir de Santa Maria de Pedralbes des de la seva fundació fins al segle XVI: un monestir reial per a l'orde de les clarisses a Catalunya, Barcelona.

Sanz Fuentes, Mạ J. y Buría Fernández, Mạ J. 2002. “El arquitecto Melchor de Velasco y el claustro del monasterio de Obona", De Arte 1: 81-88.

Schávelzon, D. y Silveira, M. 2005. "La vida cotidiana en un convento colonial: Santa Catalina de Siena a través de la Arqueología", Mundo de Antes 4: 105-126.

Seijas Montero, M. 2012. "El patrimonio de los monasterios cistercienses del sudoeste gallego en la Edad Moderna", Hispania. Revista Española de Historia 241: 423-452.

Smith, V. 2007. A History of Personal Hygiene and Purity, Oxford.

Soeiro, T. 1996-1997. "Lagares de azeite no concelho de Penafiel”, Portugalia XVII-XVIII: 219-244.

Squatriti, P. 1998. "Water, Baths and Corporeal Washing", Water and Society in Early Medieval Italy AD 400-1000, Cambridge: 44-65.

Squatriti, P. 2007. "La gestione delle risorse idriche nei complessi monastici altomedievali", en De Rubeis, F. y Marazzi, F. (eds.): Monasteri in Europa occidentale (secoli VIII-XI): topografia e strutture, Roma: 273-286.

Suárez Cortez, B. E. 1998. Historia de los usos del agua en México, México D. F.

Subiranas Fàbregas, C. y Vila Fàbregas, G. 2006. "El monestir de Sant Benet de Bages. Intervencions arqueològiques a l'església i a l'ala de llevant", III Congrés d'Arqueologia Medieval i Moderna a Catalunya, Sabadell: 631-644.

Torrente Fernández, I. 1982. El dominio del monasterio de San Bartolomé de Nava (siglos XIII-XVI), Oviedo.

Tovar Esquivel, E. 2000. Arquitectura y vida cotidiana en el convento de San Lorenzo de la ciudad de México, México D.F.

Vallés Choclán, J. A. 1998. "El abastecimiento de agua en la Puebla de Guadalupe (Cáceres)(ss. XIV-XIX). Conflictos sociales en torno a una obra hidráulica", en Bores Gamundi, F. (coord.): Actas del Il Congreso Nacional de Historia de la Construcción, A Coruña: 499-508. 
Vilar, Mạ J. 2011. "La presencia de laicos en los conventos femeninos de clausura: educandas, donados, sirvientes, operarios, médicos y señoras de piso. El caso de Santa Clara la Real de Murcia (1788-1874)", en Campos, F. J. (coord.): La clausura femenina en el Mundo hispánico: una fidelidad secular 1, El Escorial: 491-510.

Virgili, A. 2005. "L'economia monacal. Treball i renda feudal en els monestirs cistercencs", Actas del Primer CursSimposi sobre el Monaquisme Cistercenc. El Císter: Poder $i$ Espiritualitat, Santes Creus: 75-97.
Virto Ibáñez, J. J. 1991. "La desamortización del monasterio cisterciense de La Oliva (Navarra)", Príncipe de Viana 194: 145-158.

V.V.A.A. 1961. Corias Centenario 1860-1960, Oviedo.

V.V.A.A. 2004. La sidra y el vinu n'Asturies, no 13, Cultures. Revista Asturiana de Cultura, Uviéu.

Yarza Luaces, J. 1982. Arte Medieval II. Románico y Gótico, Fuentes y documentos para la historia del arte, Barcelona. 